\title{
Systematic Review on the Efficacy of Interventions for Fear of Childbirth, Anxiety and Fear in Pregnant Women
}

Carmen Birner ( $\nabla$ carmen.birner@fh-potsdam.de)

Potsdam University of Applied Sciences

\section{Gerlind Grosse}

Potsdam University of Applied Sciences

\section{Research Article}

Keywords: fear, anxiety, childbirth, pregnancy, intervention

Posted Date: February 23rd, 2021

DOI: https://doi.org/10.21203/rs.3.rs-223224/v1

License: (c) (1) This work is licensed under a Creative Commons Attribution 4.0 International License.

Read Full License 
Systematic review on the efficacy of interventions for fear of childbirth, anxiety and fear in pregnant women

\author{
Birner, Carmen ${ }^{1}$ and Grosse, Gerlind ${ }^{1}$ \\ ${ }^{1}$ Social and Education Sciences, \\ Potsdam University of Applied Sciences, \\ Potsdam, Germany
}

\begin{abstract}
Author Note
Correspondence concerning this article should be addressed to Carmen Birner via E-Mail: carmen.birner@fh.potsdam.de
\end{abstract}




\begin{abstract}
Background: Fears and anxieties during pregnancy and childbirth are a frequent phenomenon and can have negative consequences on wellbeing, psychological health and birth outcomes. Therefore, it is important to focus on the interventions to reduce those fears and anxieties during pregnancy and childbirth.
\end{abstract}

A systematic review was conducted to examine the current literature on psychological interventions to reduce anxieties and fears during pregnancy and childbirth.

Scopus and PubMed were searched from 2015 up until December 2020 for relevant studies.

Included were pregnant women, with no restriction on age ranges or parity. Entered in the review were quantitative studies, including randomized controlled trials (RCTs), non-randomized controlled trials as well as treatment evaluations. After reviewing titles, abstracts and studies, 72 studies were included in this review as they met the inclusion criteria.

Standard methodological procedures for systematic reviews were used. The quality assessment of included articles was done by using the Quality Assessment Tool for Quantitative Studies (EPHPP).

Results: The main results of this review concern the fear and anxiety reducing effects of psychoeducation, relaxation techniques, guided imagery, supportive care through a midwife, group discussion, "lifestyle based education", writing therapy, cognitive behavioral therapy groups and stress intervention, individual structured psychotherapy, communication skills training, counseling approaches (except distraction techniques), a motivational interviewing psychotherapy, emotional freedom techniques, breathing awareness and different hypnotherapeutic techniques on different fears and anxieties during pregnancy and childbirth. For mindfulness-based interventions mixed results are found. The effect of an acceptance and commitment therapy, biofeedback interventions, a mind body intervention, mental health training courses, the group intervention $\mathrm{Nyytti}$ a as well as cognitive analytic therapy is unclear, due to weak ratings. Antenatal class attendance reduced delivery fear significantly only in first time mothers. An internet-based problem-solving treatment did not reduce anxiety during pregnancy. 
Conclusion: A broad range of interventions show positive effects on fear of childbirth and fear and anxiety in pregnancy. Further research should address other acknowledged psychotherapeutic practices, like psychodynamic as well as systemic interventions, as they are underrepresented within this review. Furthermore, there is a need for manualized therapeutic interventions, with regards to a combination of effective intervention components.

Keywords: fear, anxiety, childbirth, pregnancy, intervention 


\section{Background and objectives}

\section{Background}

In the current literature, the prevalence rate of high levels of fear of childbirth is stated as $36.7 \%$ in Ireland and in India the prevalence rate of severe pregnancy anxiety levels reached up to $22 \%$ (Madhavanprabhakaran et al., 2015; Maeve A. O'Connell et al., 2019).

Women with very high scores on Fear of Childbirth (FOC) or Tocophobia often suffer under longer birth processes and stronger to unbearable pain compared to women with less fear (Adams et al., 2012; Junge et al., 2018; Laursen et al., 2009; Nettelbladt et al., 1976; Reck et al., 2013; Striebich \& Ayerle, 2020). FOC is reported as one of the most common reasons for unnecessary cesarean sections (Adams et al., 2012; Junge et al., 2018; Laursen et al., 2009; Nettelbladt et al., 1976; Reck et al., 2013; Striebich \& Ayerle, 2020). Compared to women with low levels of FOC, women with intermediate or high levels of FOC seem to have more negative birth experiences (Elvander et al., 2013). FOC can not only have a negative impact on the birth process, but also influences the wellbeing during pregnancy (Slade et al., 2019).

There is also evidence for a connection between FOC, postpartal depressions and traumatic stress symptoms (Haines et al., 2012; Räisänen et al., 2014; Söderquist et al., 2009; Striebich \& Ayerle, 2019). Furthermore, severe FOC or even anxiety may result in pre-term delivery, bonding issues and behavioral/emotional problems of the infant (Leigh \& Milgrom, 2008; O'Connor et al., 2002; Sutter-Dallay et al., 2004; Viswasam et al., 2019).

A number of systematic reviews regarding interventions to treat fear of childbirth exist in the literature of the last five years. There are general systematic reviews and meta-analyses, that list different interventions and their effect on "fear of childbirth" (MoghaddamHosseini et al., 2018; Smith et al., 2019a; Striebich et al., 2018). Further systematic reviews focus on pregnancy specific anxiety (San Lazaro Campillo et al., 2017; Stoll et al., 2018), as well a mental disorders during pregnancy (van Ravesteyn et al., 2017). 
Besides more general reviews, systematic reviews specifically focussing on mindfulness interventions (Dhillon et al., 2017; H. Hall et al., 2015; Lever Taylor et al., 2016; MatvienkoSikar et al., 2016; Riet et al., 2019; Shi \& MacBeth, 2017), psychotherapy interventions (Li et al., 2020; Ponting et al., 2020; Sockol, 2018) and e-health and technology based interventions exist (Bayrampour et al., 2019; Lee \& Cho, 2019; Loughnan, Joubert, et al., 2019; Stratton et al., 2017). Further meta-analyses focus on the effect of expressive writing on anxiety related to pregnancy (Qian et al., 2020), psychoeducation interventions (Akgün et al., 2019) and hypnosis based interventions (Catsaros \& Wendland, 2020).

The reviews of Bright et al. (2019), Brixval et al. (2014) and O'Connell et al. (2019) are not listed as only study protocols were found. The mentioned reviews included studies up to the year 2019.

The present systematic literature review is the broadest and up to December 2020 most recent overview regarding the effects of psychological interventions on fear and anxiety related to pregnancy and childbirth published in the last five years with 72 included and rated studies. While some of the past reviews focused only on certain outcome variables (e.g. only fear of childbirth as a narrow topic) (Moghaddam Hosseini et al., 2018; Smith et al., 2019b; Striebich et al., 2018), this present review focusses on broader fears and anxieties regarding the whole pregnancy and childbirth process and therefore addresses a research gap. Further previous studies examined studies until 2016, while this systematic review encloses studies up until December 2020.

The aim of this systematic review was to examine the effect of psychological interventions on "fear of childbirth" as well as fears and anxieties during pregnancy.

Previous reviews stated positive effects of psychological interventions. Hypnosis based, psychotherapeutic interventions and psychoeducation have a positive impact on fear of childbirth (Catsaros \& Wendland, 2020; Stoll et al., 2018; Swift et al., in press). There is a need to keep those findings updated and an existing research gap to review further interventions stated within the literature. 


\section{Definitions}

There is no clearly delimitable and common definition of fear of childbirth (FOC) in the literature. It is also difficult to draw a line between subclinical, phobic and pathological levels of FOC (Abdollahi et al. 2020). To give an overview over existing terms in the literature, this paper makes an attempt to define different phrases related to the term FOC. This systematic review focusses besides FOC on different anxieties and fears during pregnancy and childbirth.

FOC (Fear of Childbirth). Areskog (1982) defined „fear of childbirth“ (FOC) first in a population of Swedish pregnant women as: "a strong anxiety which had impaired their [the women's] daily functioning and wellbeing". Later, during the 2000s, a study from Sweden defined FOC as belonging to "the family of anxiety disorders" (Zar et al., 2002).

Klabbers (2016) pointed out, that FOC is an anxiety disorder or phobic fear.

In the classification of diseases - 10 (ICD 10) fear of childbirth could most likely be listed under code 099.8 as "other specific diseases and conditions complicating pregnancy, childbirth, or puerperium" (Størksen et al., 2015).

Wijma (2003) describes "clinical FOC", as a "disabling fear that interferes with occupational or academic functioning, with domestic and social activities or with relationships". The symptoms of FOC could be characterised as "worries or extreme fear" (Poggi et al., 2018).

FOC has different manifestations. It is "assumed to be a continuum with no or low fear on one end, and severe or extreme fear on the other" and is clinically relevant "if it affects a woman's quality of life" (Striebich et al., 2018).

FOC can also be classified into primary FOC, which occurs in nulliparous women and secondary FOC relating to women who already had traumatic birth experiences (Abdollahi et al., 2020; K Hofberg \& Ward, 2003). A third form is FOC as a symptom of prenatal depression (K Hofberg \& Ward, 2003; Kristina Hofberg \& Brockington, 2000; Klabbers, 2016). 
Tocophobia. Primary tocophobia is defined as "severe fear precedes conception and leads to avoidance of tokos (Greek: childbirth)", while secondary tokophobia is a "phobic fear resulting from a distressing or even traumatising childbirth experience" (Striebich et al., 2018). It is characterised as an "unreasoning dread of childbirth" relating to women in a "specific and harrowing condition" including a "pathological dread" and "avoidance of childbirth" (Kristina Hofberg \& Brockington, 2000). Tocophobia is „, a specific anxiety or fear of death during parturition precedes pregnancy“ that is "so intense that tokos (childbirth) is avoided whenever possible; this is a phobic state called tocophobia"' (Kristina Hofberg \& Ward, 2004).

Bhatia and Jhanjee (2012) defined tokophobia as "a pathological fear of pregnancy" and indicated the pathological aspect of tokophobia, which can result in avoidance of childbirth (Poggi et al., 2018). The authors distinguish tocophobia - similar to the classification of FOC between primary fear of childbirth, in women without previous pregnancy experience and secondary fear of childbirth related to a „traumatic obstetric event in previous pregnancy” (Poggi et al., 2018).

Tocophobia often is defined by $\geq 85 / 165$ points on the Assessments Wijma Delivery Expectancy Questionnaire (W-DEQ A) (Maeve A. O'Connell et al., 2017; Striebich \& Ayerle, 2020) A recent systematic review determined tocophobia to be synonymous with severe FOC (Maeve A. O'Connell et al., 2017). Based on this conclusion this present paper also refers to severe/high FOC as synonymous to tokophobia.

Childbirth Anxiety. Wijma and Wijma (2017) define childbirth anxiety as follows: "When a woman is afraid of the situation where a child will or is to be born [...] CA covers the whole continuum from a little fear that is easy to cope with to phobic fear, when the woman wants to avoid the situation by all means".

Perinatal Anxiety (PNA) and Perinatal Generalized Anxiety Disorder (GAD). Harrison, Moore and Lazard (2020) characterized the term perinatal anxiety and Misri et al. (2015) introduced the term Perinatal Generalized Anxiety Disorder (GAD), which is defined as "excessive, uncontrollable worry that can cause functional impairment". 
Further forms of pregnant related anxieties. Pregnancy can be accompanied by a variety of anxiety disorders, like panic, disorder with or without agoraphobia, obsessive-compulsive disorder, generalized anxiety disorder, specific phobia, social anxiety disorder and posttraumatic stress disorder (Viswasam et al., 2019).

\section{Methods}

\section{Criteria for considering studies}

Papers included in this systematic review were limited to publications in English and German language only with the restriction for publication year between 2015 and December 2020.

\section{Inclusion criteria}

The inclusion criteria for this systematic review were outcomes regarding fears or anxieties during pregnancy and childbirth. Different definitions of the concept "fear of childbirth" and the understanding of fears and anxieties during childbirth were admitted. Besides, varying outcome measurements were valid. Pregnant women (both primi- and/or multiparous) with no restriction to age ranges were included. The interventions were restricted to psychological interventions, biofeedback interventions, mindfulness-based interventions and midwife counselling studies. Included studies focused on the prenatal period. Only intervention studies were included (no correlation studies about personality traits).

\section{Exclusion criteria}

Excluded were study protocols, qualitative studies, reviews, case series designs, case reports, consensus bundles, medical research counsel frameworks, studies with no described study design and uncorrected proof studies. Studies of pregnant women with specific somatic complains, (in)fertility or abortion studies, yoga interventions, pharmacological interventions (including psychopharmacology), music interventions, spiritual interventions, art therapy as 
only intervention, and aroma therapy studies were excluded. Not included were medical studies, studies on pregnancy loss or sleeping problems, postpartum studies, traumatic birth studies, studies focusing on depression only, sport or physical activity interventions, studies relating to stillbirth, and ultrasound interventions. Studies written in other languages than German or English were also excluded.

\section{Search methods for identification of studies}

The electronic databases PubMed and Scopus were searched for articles using the terms “fear", "anxiety", "pregnancy", “childbirth”, “intervention” from 2015 up to December 2020.

The initial search yielded a total of 3029 studies, after setting the time (year 2015-2020) and language filters a total of 2027 studies were displayed and a total of 1426 studies were screened for this review, after removing all duplicates. Further studies were excluded as they were either not relevant to the review or did not meet the inclusion criteria or were not found. 72 records were screened. See figure 1 for the summary of search item identification. For the final included studies and their results see table 2.

\section{Data collection and analysis}

One person was included in the data collection, management and analysis of the studies. No software tools were used to support selection of studies. With an excel programme duplicates were analyzed. No standardized data collection forms were used. The data items are described in table 2. 


\section{Figure 1}

Systematic Review Profile based on the prisma flow diagram (Moher et al., 2009)

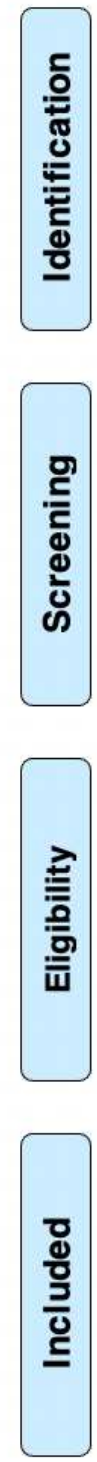

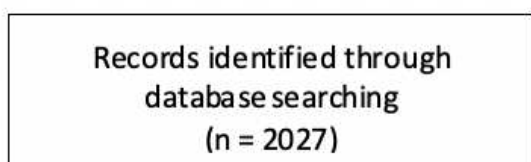

( $n=2027$ )
Additional records identified through other sources

$$
(n=0)
$$




\section{Quality assessment and risk of bias in included studies}

Of the 72 studies included, 22, 31 and 19, respectively, received a strong, moderate and weak rating on the "Quality Assessment Tool for Quantitative Studies" of the "Effective Public Health Practice Project (EPHPP)". The risk of bias in the included studies was assessed with this tool. One author was involved in the assessment of risk of bias in included studies. All studies (strong, moderate, weak ratings) were included in the analysis and interpretation. The ratings are listed in table 1.

\section{Table 1}

Ratings of included studies based on the "Quality Assessment Tool for Quantitative Studies" of the "Effective Public Health Practice Project $(E P H P P) "$

\begin{tabular}{|l|l|l|l|l|l|l|l|}
\hline & & Selection Bias & Study Design & Confounders & \multicolumn{1}{|c|}{ Blinding } & $\begin{array}{c}\text { Data } \\
\text { collection } \\
\text { method }\end{array}$ & $\begin{array}{c}\text { Withdrawals } \\
\text { and dropouts }\end{array}$ \\
Global rating \\
of paper
\end{tabular}




\begin{tabular}{|c|c|c|c|c|c|c|c|c|}
\hline & & Selection Bias & Study Design & Confounders & Blinding & $\begin{array}{c}\text { Data } \\
\text { collection } \\
\text { method }\end{array}$ & $\begin{array}{l}\text { Withdrawals } \\
\text { and dropouts }\end{array}$ & $\begin{array}{c}\text { Global rating } \\
\text { of paper }\end{array}$ \\
\hline (4) & Zarenejad (2020) & moderate & strong & strong & moderate & strong & strong & strong \\
\hline (5) & Firouzan (2020) & strong & strong & strong & moderate & strong & strong & strong \\
\hline (6) & Kang (2020) & moderate & strong & weak & moderate & strong & weak & weak \\
\hline (7) & Goetz (2020) & moderate & moderate & weak & moderate & strong & weak & weak \\
\hline (8) & Alipour (2020) & moderate & strong & strong & strong & strong & weak & moderate \\
\hline (9) & Sridhar (2020) & moderate & strong & strong & strong & strong & moderate & strong \\
\hline (10) & Esfandiari (2020) & moderate & strong & weak & strong & strong & moderate & moderate \\
\hline (11) & Mirtabar (2020) & moderate & strong & strong & strong & strong & strong & strong \\
\hline$(12)$ & Abbasi (2020) & strong & strong & strong & weak & strong & strong & moderate \\
\hline (13) & Larsson (in press) & weak & strong & strong & weak & weak & weak & weak \\
\hline (14) & Swift (in press) & moderate & strong & strong & strong & moderate & moderate & strong \\
\hline (15) & Shahsavan (2020) & strong & moderate & strong & moderate & strong & strong & strong \\
\hline (16) & Boz (2020) & moderate & strong & strong & moderate & strong & weak & moderate \\
\hline (17) & Abdollahi (2020) & weak & strong & strong & moderate & strong & strong & moderate \\
\hline (18) & Hamilton (2020) & weak & strong & weak & weak & strong & weak & weak \\
\hline (19) & Noorbala (2019) & moderate & strong & strong & moderate & strong & weak & moderate \\
\hline
\end{tabular}




\begin{tabular}{|c|c|c|c|c|c|c|c|c|}
\hline & & Selection Bias & Study Design & Confounders & Blinding & $\begin{array}{c}\text { Data } \\
\text { collection } \\
\text { method }\end{array}$ & $\begin{array}{l}\text { Withdrawals } \\
\text { and dropouts }\end{array}$ & $\begin{array}{c}\text { Global rating } \\
\text { of paper }\end{array}$ \\
\hline (20) & Uludağ (2020) & moderate & strong & strong & moderate & weak & strong & moderate \\
\hline$(21)$ & Rajeswari (2020) & moderate & strong & weak & moderate & strong & strong & moderate \\
\hline (22) & Bazrafsahn (2020) & strong & strong & strong & moderate & strong & strong & strong \\
\hline (23) & Munkhondya (2020) & moderate & strong & strong & moderate & strong & strong & strong \\
\hline (24) & Price (2019) & moderate & moderate & weak & moderate & strong & strong & moderate \\
\hline (25) & Yang (2019) & moderate & strong & strong & moderate & strong & strong & strong \\
\hline (26) & van der Zwan (2019) & moderate & strong & strong & weak & strong & weak & weak \\
\hline$(27)$ & Loughnan (2019) & moderate & strong & weak & moderate & strong & weak & weak \\
\hline$(28)$ & Zemestani (2019) & strong & strong & strong & moderate & strong & strong & strong \\
\hline (29) & Amiri (2019) & moderate & strong & strong & moderate & strong & strong & strong \\
\hline (30) & Rahmani (2019) & strong & strong & strong & weak & strong & strong & moderate \\
\hline (31) & Zhang (2019) & moderate & strong & strong & moderate & strong & weak & moderate \\
\hline (32) & Hildingsson (2019) & weak & strong & strong & moderate & strong & strong & strong \\
\hline (33) & Klabbers (2019) & strong & strong & strong & weak & strong & weak & weak \\
\hline (34) & Irmak Vural (2019) & moderate & strong & strong & moderate & strong & strong & strong \\
\hline (35) & Heller (2020) & moderate & strong & weak & moderate & strong & moderate & moderate \\
\hline
\end{tabular}




\begin{tabular}{|c|c|c|c|c|c|c|c|c|}
\hline & & Selection Bias & Study Design & Confounders & Blinding & $\begin{array}{c}\text { Data } \\
\text { collection } \\
\text { method }\end{array}$ & $\begin{array}{l}\text { Withdrawals } \\
\text { and dropouts }\end{array}$ & $\begin{array}{c}\text { Global rating } \\
\text { of paper }\end{array}$ \\
\hline (36) & Mohammadi (2019) & strong & strong & strong & weak & strong & strong & moderate \\
\hline (37) & Ekrami (2019) & moderate & strong & strong & moderate & strong & strong & strong \\
\hline (38) & Sobhani (2019) & moderate & strong & weak & moderate & strong & weak & weak \\
\hline (39) & $\begin{array}{l}\text { Kacperczyk-Bartnik } \\
(2019)\end{array}$ & moderate & weak & strong & moderate & strong & strong & moderate \\
\hline (40) & Uçar \& Golbasi (2019) & weak & moderate & strong & moderate & strong & weak & weak \\
\hline (41) & Narita (2018) & moderate & moderate & strong & weak & strong & weak & weak \\
\hline$(42)$ & Boryri (2018) & moderate & moderate & strong & moderate & strong & weak & moderate \\
\hline (43) & Warriner (2018) & moderate & weak & weak & moderate & strong & weak & weak \\
\hline (44) & Akbarian (2018) & moderate & strong & weak & moderate & strong & weak & weak \\
\hline (45) & Krusche (2018) & strong & strong & strong & moderate & strong & weak & moderate \\
\hline (46) & Rondung (2018) & moderate & strong & strong & strong & weak & strong & moderate \\
\hline$(47)$ & Hajmohamadi (2018) & strong & strong & strong & moderate & weak & strong & moderate \\
\hline (48) & Airo (Toivanen) (2018) & weak & strong & weak & moderate & weak & strong & weak \\
\hline (49) & Duncan (2017) & moderate & strong & weak & moderate & strong & strong & moderate \\
\hline$(50)$ & Andaroon (2017) & strong & strong & weak & moderate & strong & strong & moderate \\
\hline
\end{tabular}




\begin{tabular}{|c|c|c|c|c|c|c|c|c|}
\hline & & Selection Bias & Study Design & Confounders & Blinding & $\begin{array}{c}\text { Data } \\
\text { collection } \\
\text { method }\end{array}$ & $\begin{array}{l}\text { Withdrawals } \\
\text { and dropouts }\end{array}$ & $\begin{array}{c}\text { Global rating } \\
\text { of paper }\end{array}$ \\
\hline (51) & Seyed (2017) & moderate & strong & strong & moderate & strong & strong & strong \\
\hline (52) & Mary (2017) & moderate & moderate & weak & moderate & strong & weak & weak \\
\hline (53) & Legrand (2017) & weak & weak & - & - & strong & moderate & weak \\
\hline (54) & Waisblat (2017) & strong & moderate & strong & moderate & weak & strong & moderate \\
\hline (55) & Toosi (2017) & moderate & strong & strong & strong & moderate & strong & moderate \\
\hline (56) & Sanaati (2017) & strong & strong & strong & moderate & strong & strong & strong \\
\hline (57) & Kordi (2017) & moderate & strong & strong & moderate & strong & strong & strong \\
\hline (58) & Beattie (2017) & moderate & strong & strong & strong & strong & weak & moderate \\
\hline (59) & Haapio (2017) & weak & strong & strong & moderate & weak & moderate & weak \\
\hline (60) & Parsa (2016) & moderate & moderate & strong & moderate & strong & strong & strong \\
\hline (61) & Aslami (2016) & moderate & moderate & strong & moderate & strong & weak & moderate \\
\hline (62) & Khojasteh (2016) & moderate & strong & strong & moderate & strong & weak & moderate \\
\hline (63) & Sheikh-Azadi (2016) & moderate & strong & strong & moderate & strong & weak & moderate \\
\hline (64) & Salehi (2016) & strong & strong & strong & moderate & strong & strong & strong \\
\hline (65) & Beevi (2016) & moderate & moderate & strong & moderate & strong & weak & moderate \\
\hline
\end{tabular}




\begin{tabular}{|c|c|c|c|c|c|c|c|c|}
\hline & & Selection Bias & Study Design & Confounders & Blinding & $\begin{array}{l}\text { Data } \\
\text { collection } \\
\text { method }\end{array}$ & $\begin{array}{l}\text { Withdrawals } \\
\text { and dropouts }\end{array}$ & $\begin{array}{c}\text { Global rating } \\
\text { of paper }\end{array}$ \\
\hline (66) & Fontein-Kuipers (2016) & moderate & strong & strong & moderate & strong & moderate & strong \\
\hline (67) & Yazdanimehr (2016) & moderate & strong & strong & moderate & strong & moderate & strong \\
\hline (68) & Nieminen (2016) & moderate & moderate & weak & weak & strong & weak & weak \\
\hline (69) & Karabulut (2016) & moderate & moderate & strong & moderate & strong & moderate & strong \\
\hline (70) & Karamoozian (2015) & moderate & strong & strong & moderate & strong & weak & moderate \\
\hline (71) & Rouhe (2015a) & weak & strong & strong & moderate & strong & weak & weak \\
\hline$(72)$ & İsbir (2015) & moderate & strong & strong & moderate & strong & strong & strong \\
\hline
\end{tabular}




\section{Dealing with missing data}

Few studies without access were excluded from analysis: Nasiri et al. (2018), Kao et al. (2017), Jahdi et al. (2016), Anton and David (2015), Soltani et al. (2017), Najafi et al. (2019), Hennelly et al. (2020). No authors or sponsors were contacted to obtain missing information or clarify the information available. Missing data (e.g. the period of time of data collection) within the viewed studies were marked as such in table 2 .

\section{Results}




\section{Description of Studies}

\section{Table 2}

Summary of the included studies

\begin{tabular}{|c|c|c|c|c|c|c|c|}
\hline & $\begin{array}{l}\text { First Au- } \\
\text { tor, Year }\end{array}$ & $\begin{array}{l}\text { Country/ } \\
\text { date of data } \\
\text { collection/ } \\
\text { study design/ } \\
\text { EPHPP rating }\end{array}$ & $\begin{array}{l}\text { Target popu- } \\
\text { lation (sam- } \\
\text { ple size/age } \\
\text { (mean, } \pm \\
\text { SD)/parity) }\end{array}$ & $\begin{array}{l}\text { Intervention/ } \\
\text { comparators }\end{array}$ & $\begin{array}{l}\text { Study outcome: } \\
\text { Interventions } \\
\text { Key findings }\end{array}$ & $\begin{array}{l}\text { Measurements } \\
\text { (for fear and } \\
\text { anxiety during } \\
\text { childbirth and } \\
\text { FOC) }\end{array}$ & $\begin{array}{l}\text { For this } \\
\text { study rel- } \\
\text { evant re- } \\
\text { search } \\
\text { topic }\end{array}$ \\
\hline (1) & $\begin{array}{l}\text { Aksoy } \\
\text { Derya } \\
(2021)\end{array}$ & $\begin{array}{l}\text { Turkey } \\
2020 \\
\text { RCT } \\
\text { moderate }\end{array}$ & $\begin{array}{l}N=96 \\
\text { Age: } \\
\text { IG: } 28.70 \pm \\
4.73 \\
\text { CG: } 28.06 \pm \\
4.12 \\
\text { Not stated if } \\
\text { primi- or/and } \\
\text { multiparous }\end{array}$ & $\begin{array}{l}\text { IG: individual } \\
\text { tele-education } \\
\text { (interactive edu- } \\
\text { cation and con- } \\
\text { sultancy pro- } \\
\text { vided by phone } \\
\text { calls, text mes- } \\
\text { sage and digital } \\
\text { education book- } \\
\text { let) } \\
\text { CG: No inter- } \\
\text { vention }\end{array}$ & $\begin{array}{l}\text { The posttest PRAQ-R2 total mean scores } \\
(\mathrm{t}=-4.095, \mathrm{p}=.000) \text { of the pregnant women } \\
\text { in the IG and CG, as well as the subscales } \\
\text { "fear of giving birth" ( } \mathrm{t}=-3.275, p=.001) \text { and } \\
\text { "worries of bearing a physically or mentally } \\
\text { handicapped child" ( } \mathrm{t}=-4.354, p=.000) \\
\text { showed a statistically significant difference } \\
\text { between the groups. } \\
\text { The subscale "concerns about own ap- } \\
\text { pearance" did not show a statistical differ- } \\
\text { ence between the groups. } \\
\text { When the intragroup comparisons of the } \\
\text { pre- and posttest in the IG were examined, } \\
\text { their "pretest prenatal distress", "fear of giv- } \\
\text { ing birth", "worries of bearing a physically } \\
\text { or mentally handicapped child" and "preg- } \\
\text { nancy-related anxiety" total mean scores } \\
\text { were significantly lower than their posttest } \\
\text { mean scores ( } p<.05) \text {. In the CG only the } \\
\text { "pretest fear of giving birth" subscale mean } \\
\text { score was significantly lower than the post- } \\
\text { test mean score }(p<.05) \text {. }\end{array}$ & $\begin{array}{l}\text { Pregnancy Re- } \\
\text { lated Anxiety } \\
\text { Questionnaire- } \\
\text { Revised-2 } \\
\text { (PRAQ-R2) } \\
\text { "Revised Prena- } \\
\text { tal Distress } \\
\text { Questionnaire } \\
\text { (NuPDQ)" }\end{array}$ & $\begin{array}{l}\text { Preg- } \\
\text { nancy re- } \\
\text { lated } \\
\text { anxiety }\end{array}$ \\
\hline
\end{tabular}




\begin{tabular}{|c|c|c|c|c|c|c|c|}
\hline (2) & $\begin{array}{l}\text { Montazeri } \\
(2020)\end{array}$ & $\begin{array}{l}\text { Iran } \\
2018 \\
\text { RCT } \\
\text { moderate }\end{array}$ & $\begin{array}{l}N=70 \\
\text { Age: } \\
\text { IG: } 27.5 \pm 5.9 \\
\text { CG: } 27.7 \pm 5.8 \\
\text { Primi- and } \\
\text { Multiparous }\end{array}$ & $\begin{array}{l}\text { IG: Three proto- } \\
\text { col-based writ- } \\
\text { ing therapy ses- } \\
\text { sions } \\
\text { CG: routine } \\
\text { pregnancy care }\end{array}$ & $\begin{array}{l}\text { The results of the independent } t \text {-test } \\
\text { showed no significant difference in the } \\
\text { mean score of pre-intervention anxiety in } \\
\text { the IG and CG ( } p=.287) \text {. According to AN- } \\
\text { COVA with baseline score adjustment, the } \\
\text { score of anxiety had a significant reduction } \\
\text { in the IG compared to the CG (adjusted } \\
\text { mean difference: }-6.8 ; 95 \% \text { confidence in- } \\
\text { terval: }-9.1 \text { to }-4.5 ; p<.001 \text { ). }\end{array}$ & $\begin{array}{l}\text { Beck anxiety in- } \\
\text { ventory }\end{array}$ & $\begin{array}{l}\text { Anxiety } \\
\text { during } \\
\text { preg- } \\
\text { nancy }\end{array}$ \\
\hline (3) & $\begin{array}{l}\text { Waters } \\
\text { (2020) }\end{array}$ & $\begin{array}{l}\text { UK } \\
\text { Date of data } \\
\text { collection not } \\
\text { stated } \\
\text { open-label pi- } \\
\text { lot study } \\
\text { weak }\end{array}$ & $\begin{array}{l}\text { N=74 } \\
\text { Age: } \\
33.5 \text { (3.87) } \\
\text { Primi- and } \\
\text { Multiparous }\end{array}$ & $\begin{array}{l}\text { 8-week, group- } \\
\text { delivered Ac- } \\
\text { ceptance and } \\
\text { Commitment } \\
\text { Therapy (ACT) } \\
\text { intervention }\end{array}$ & $\begin{array}{l}\text { At post-treatment, } 38 \text { of } 55 \text { women }(69 \%) \\
\text { demonstrated a statistically reliable de- } \\
\text { crease in global distress }(d=0.99) \text {. }\end{array}$ & 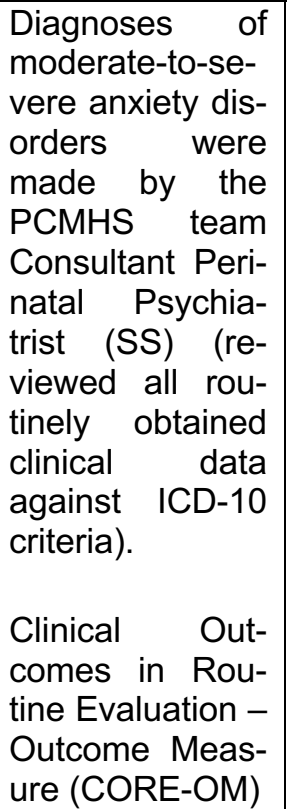 & $\begin{array}{l}\text { Perinatal } \\
\text { mood and } \\
\text { anxiety } \\
\text { disorders }\end{array}$ \\
\hline (4) & $\begin{array}{l}\text { Zarenejad } \\
(2020)\end{array}$ & $\begin{array}{l}\text { Iran } \\
\text { Date of data } \\
\text { collection not } \\
\text { stated } \\
\text { RCT } \\
\text { strong }\end{array}$ & $\begin{array}{l}N=70 \\
\text { Age: } \\
\text { IG: } 27 \pm 5 \\
\text { CG: } 24.5 \pm 50 \\
\text { Not stated if } \\
\text { primi- or/and } \\
\text { multiparous }\end{array}$ & $\begin{array}{l}\text { IG: received } 6 \\
\text { mindfulness- } \\
\text { based stress re- } \\
\text { duction } \\
\text { (MBSR) training } \\
\text { sessions } \\
\text { CG: routine care }\end{array}$ & $\begin{array}{l}\text { The results of analysis of variance with re- } \\
\text { peated measures in assessing the } \\
\text { changes in pregnancy anxiety score be- } \\
\text { fore, immediately after, and } 1 \text { month after } \\
\text { the intervention showed that the length of } \\
\text { time affects the anxiety score of pregnancy } \\
\text { by decreasing it }(p=.03) \text { and that a signifi- } \\
\text { cant difference was observed between the } \\
\text { two groups in this regard }(p=.001) \text {. After } \\
\text { the intervention, the CG showed significant }\end{array}$ & $\begin{array}{l}\text { Pregnancy-Re- } \\
\text { lated Anxiety } \\
\text { Questionnaire }\end{array}$ & $\begin{array}{l}\text { Preg- } \\
\text { nancy re- } \\
\text { lated } \\
\text { anxiety }\end{array}$ \\
\hline
\end{tabular}




\begin{tabular}{|c|c|c|c|c|c|c|c|}
\hline & & & & & $\begin{array}{l}\text { higher scores in anxiety compared to the } \\
\text { IG. }\end{array}$ & & \\
\hline (5) & $\begin{array}{l}\text { Firouzan } \\
(2020)\end{array}$ & $\begin{array}{l}\text { Iran } \\
2019 \\
\text { RCT } \\
\text { strong }\end{array}$ & $\begin{array}{l}N=80 \\
\text { Age: } \\
\text { IG: } 26.27 \pm \\
4.48 \\
\text { CG: } 25.87 \pm \\
4.58 \\
\text { Primiparous }\end{array}$ & $\begin{array}{l}\text { IG: face-to-face } \\
\text { counselling ses- } \\
\text { sions based on } \\
\text { the BELIEF pro- } \\
\text { tocol + tele- } \\
\text { phone-counsel- } \\
\text { ling sessions } \\
\text { CG: prenatal } \\
\text { routine care }\end{array}$ & $\begin{array}{l}\text { After adjusting for the pretest scores, there } \\
\text { was a significant difference between the IG } \\
\text { and } C G \text { on post-test scores of W-DEQ-A } \\
(F(1,65)=100.42, \quad p=.0001, \text { partial eta } \\
\text { squared }=.60) \text {. The IG got lower scores on } \\
\text { W-DEQ-A at post-test than the CG, indicat- } \\
\text { ing that the BELIEF protocol was effective } \\
\text { in decreasing childbirth fear. }\end{array}$ & W-DEQ A & FOC \\
\hline (6) & $\begin{array}{l}\text { Kang } \\
(2020)\end{array}$ & $\begin{array}{l}\text { China } \\
\text { 2012-2014 } \\
\text { RCT } \\
\text { weak }\end{array}$ & $\begin{array}{l}N=100 \\
\text { Age: } 26.9 \pm \\
1.5 \\
\text { Primi- and } \\
\text { multi-parous }\end{array}$ & $\begin{array}{l}\text { IG: psychologi- } \\
\text { cal intervention } \\
\text { CG: Routine } \\
\text { Nursing Care }\end{array}$ & $\begin{array}{l}\text { Postoperative SAS scores were signifi- } \\
\text { cantly lower in the IG than in the CG and } \\
\text { the differences were statistically significant } \\
(p<0.01) \text {. In the CG, differences in anxiety } \\
\text { and fear levels were not statistically signif- } \\
\text { icant between preoperation and postoper- } \\
\text { ation }(p>0.05) \text {. }\end{array}$ & $\begin{array}{l}\text { Self-rating Anxi- } \\
\text { ety Scale (SAS) }\end{array}$ & $\begin{array}{l}\text { Anxiety of } \\
\text { pregnant } \\
\text { women } \\
\text { undergo- } \\
\text { ing inter- } \\
\text { ventional } \\
\text { prenatal } \\
\text { diagnosis }\end{array}$ \\
\hline (7) & $\begin{array}{l}\text { Alipour } \\
(2020)\end{array}$ & $\begin{array}{l}\text { Iran } \\
2017-2018 \\
\text { RCT } \\
\text { moderate }\end{array}$ & $\begin{array}{l}N=54 \\
\text { Age: } \\
\text { IG: } 29.1(4.3) \\
\text { CG: } 29.4(4.5) \\
\text { Primi- and } \\
\text { multiparous }\end{array}$ & $\begin{array}{l}\text { IG: communica- } \\
\text { tion skills train- } \\
\text { ing package + } \\
\text { couple-based in- } \\
\text { tervention } \\
\text { CG: two ses- } \\
\text { sions of child- } \\
\text { birth preparation } \\
+ \text { after the com- } \\
\text { pletion of the } \\
\text { third phase of } \\
\text { the study: given } \\
\text { educational } \\
\text { pamphlets }\end{array}$ & $\begin{array}{l}\text { The level of anxiety three months after in- } \\
\text { tervention was lower }(p=.001) \text { in the IG } \\
\text { than in the CG. The results showed the im- } \\
\text { pact of group in the level of anxiety } \\
(p<.001) \text { was significant. During the study } \\
\text { follow-ups in the IG, a significant change in } \\
\text { the level of anxiety }(p<.001) \text { occurred. }\end{array}$ & $\begin{array}{l}\text { Questions re- } \\
\text { lated to the sub- } \\
\text { scales of de- } \\
\text { pression and } \\
\text { anxiety of Gen- } \\
\text { eral Health } \\
\text { Questionnaire } \\
\text { (GHQ) }\end{array}$ & $\begin{array}{l}\text { Anxiety } \\
\text { during } \\
\text { preg- } \\
\text { nancy }\end{array}$ \\
\hline
\end{tabular}




\begin{tabular}{|c|c|c|c|c|c|c|c|}
\hline (8) & $\begin{array}{l}\text { Goetz } \\
(2020)\end{array}$ & $\begin{array}{l}\text { Germany } \\
2019 \\
\text { prospective pi- } \\
\text { lot study with } \\
\text { an explorative } \\
\text { study design } \\
\text { weak }\end{array}$ & $\begin{array}{l}N=68 \\
\text { Age: } 32.07 \\
(4.74) \\
\text { Primi- and } \\
\text { multiparous }\end{array}$ & $\begin{array}{l}\text { Intervention: } \\
\text { electronic Mind- } \\
\text { fulness-based } \\
\text { interventions } \\
\text { (eMBls) }\end{array}$ & $\begin{array}{l}\text { After completing the } 1 \text {-week electronic } \\
\text { course on mindfulness, the participants } \\
\text { showed a significant reduction in the mean } \\
\text { state anxiety levels }(p<.05) \text {. }\end{array}$ & $\begin{array}{l}\text { State-Trait Anxi- } \\
\text { ety Inventory } \\
\text { (STAI-S) } \\
\text { Pregnancy-Re- } \\
\text { lated Anxiety } \\
\text { Questionnaire } \\
\text { (PRAQ-R) }\end{array}$ & $\begin{array}{l}\text { Preg- } \\
\text { nancy re- } \\
\text { lated anx- } \\
\text { iety } \\
\text { State/ } \\
\text { Trait Anxi- } \\
\text { ety }\end{array}$ \\
\hline (9) & $\begin{array}{l}\text { Sridhar } \\
(2020)\end{array}$ & $\begin{array}{l}\text { USA } \\
2018 \\
\text { Pilot feasability } \\
\text { study } \\
\text { moderate }\end{array}$ & $\begin{array}{l}N=30 \\
\text { Age: } 30.1(7.4) \\
\text { Not stated if } \\
\text { primi- or/and } \\
\text { multiparous }\end{array}$ & $\begin{array}{l}\text { IG: Participants } \\
\text { could choose } \\
\text { any of the three } \\
\text { available virtual } \\
\text { reality (VR) en- } \\
\text { vironments } \\
\text { (dream beach, } \\
\text { Iceland, dol- } \\
\text { phins) } \\
\text { CG: receiving } \\
\text { standard care }\end{array}$ & $\begin{array}{l}\text { The median decrease in the VAS anxiety } \\
\text { score from before to after the procedure } \\
\text { was greater in the IG than in the CG (Wil- } \\
\text { coxon rank-sum, } p=.3324 \text { ) } \\
\text { All but one participant reported that VR } \\
\text { was either very effective ( } 53 \%) \text { or some- } \\
\text { what effective ( } 40 \% \text { ) in relieving anxiety } \\
\text { during and after the procedure. }\end{array}$ & $\begin{array}{l}\text { Modified Am- } \\
\text { sterdam Pre- } \\
\text { operative Anxi- } \\
\text { ety and Infor- } \\
\text { mation Scale } \\
\text { (APAIS) + a vis- } \\
\text { ual analogue } \\
\text { scale (VAS) for } \\
\text { anxiety, ranging } \\
\text { from } 0 \text { (mini- } \\
\text { mum anxiety) to } \\
10 \text { (maximum } \\
\text { anxiety) }\end{array}$ & $\begin{array}{l}\text { Anxiety } \\
\text { during } \\
\text { preg- } \\
\text { nancy }\end{array}$ \\
\hline (10) & $\begin{array}{l}\text { Esfandiari } \\
(2020)\end{array}$ & $\begin{array}{l}\text { Iran } \\
\text { 2018-2019 } \\
\text { RCT } \\
\text { moderate }\end{array}$ & $\begin{array}{l}N=80 \\
\text { Age: } \\
\text { IG: } \\
27.87(5.26) \\
\text { CG: } \\
23.72(4.27) \\
\text { Primi- and } \\
\text { Multiparous }\end{array}$ & $\begin{array}{l}\text { IG: group sup- } \\
\text { portive counsel- } \\
\text { ing (SC) } \\
\text { CG: antenatal } \\
\text { usual care } \\
\text { (AUC) }\end{array}$ & $\begin{array}{l}\text { In the IG scores of state-anxiety were re- } \\
\text { duced more remarkably than in the CG } \\
\text { with a large effect size }(B=-8.47, \quad p= \\
\left.<0.001, \eta^{2}=0.40\right) \text {. }\end{array}$ & $\begin{array}{l}\text { Spielberger } \\
\text { State-Anxiety In- } \\
\text { ventory (STAl- } \\
\text { Y). }\end{array}$ & $\begin{array}{l}\text { State an- } \\
\text { xiety dur- } \\
\text { ing preg- } \\
\text { nancy }\end{array}$ \\
\hline (11) & $\begin{array}{l}\text { Mirtabar } \\
(2020)\end{array}$ & $\begin{array}{l}\text { Iran } \\
\text { 2017-2018 } \\
\text { RCT }\end{array}$ & $\begin{array}{l}N=60 \\
\text { Age: } \\
29.0 \pm 5\end{array}$ & $\begin{array}{l}\text { IG: received in- } \\
\text { dividual struc- } \\
\text { tured psycho- } \\
\text { therapy + pre- }\end{array}$ & $\begin{array}{l}\text { Both the IG and CG had significant reduc- } \\
\text { tions in the mean scores of state-anxiety } \\
\text { and pregnancy distress from the baseline } \\
\text { to end of study }(p<.05) \text {. The ANCOVA tests }\end{array}$ & $\begin{array}{l}\text { State-Anxiety In- } \\
\text { ventory (STAI) }\end{array}$ & $\begin{array}{l}\text { State anx- } \\
\text { iety in } \\
\text { preterm } \\
\text { labor }\end{array}$ \\
\hline
\end{tabular}




\begin{tabular}{|c|c|c|c|c|c|c|c|}
\hline & & strong & $\begin{array}{l}\text { Primi- and } \\
\text { Multiparous }\end{array}$ & $\begin{array}{l}\text { term labor inpa- } \\
\text { tient medical } \\
\text { care } \\
\text { CG: inpatient } \\
\text { medical care for } \\
\text { preterm labor }\end{array}$ & $\begin{array}{l}\text { determined that the IG had a significant im- } \\
\text { provement in the state-anxiety scores } \\
\text { compared with the CG }(p<.001) \text {. }\end{array}$ & & $\begin{array}{l}\text { Preg- } \\
\text { nancy dis- } \\
\text { tress }\end{array}$ \\
\hline (12) & $\begin{array}{l}\text { Abbasi } \\
(2020)\end{array}$ & $\begin{array}{l}\text { Iran } \\
\text { 2015-2016 } \\
\text { RCT } \\
\text { moderate }\end{array}$ & $\begin{array}{l}N=153 \\
\text { Age: } \\
\text { IG Educational } \\
\text { software :25.5 } \\
(3.8) \\
\text { IG: Educa- } \\
\text { tional Booklet: } \\
25.9 \text { (3.6) } \\
\text { Control: } 25.1 \\
\text { (3.2) } \\
\text { Primiparous }\end{array}$ & $\begin{array}{l}\text { IG Educational } \\
\text { software: stud- } \\
\text { ied the educa- } \\
\text { tional content of } \\
\text { the educational } \\
\text { software } \\
\text { IG: Educational } \\
\text { Booklet: studied } \\
\text { the educational } \\
\text { content of the } \\
\text { educational } \\
\text { booklet } \\
\text { CG: routine care }\end{array}$ & $\begin{array}{l}\text { The average state anxiety score in the ed- } \\
\text { ucational software group and the educa- } \\
\text { tional booklet group was significantly lower } \\
\text { than the CG }(p<.001) \text {. Also, the mean state } \\
\text { anxiety score in the educational software } \\
\text { group was significantly decreased com- } \\
\text { pared to the educational booklet group af- } \\
\text { ter the intervention }(p<.001) \text {. } \\
\text { The average score of trait anxiety in the ed- } \\
\text { ucational software group and the educa- } \\
\text { tional booklet group was significantly lower } \\
\text { than the control group }(p<.001) \text {. Also, there } \\
\text { was no significant difference between the } \\
\text { two intervention groups }(p=.952)\end{array}$ & $\begin{array}{l}\text { State-Anxiety In- } \\
\text { ventory (STAI) }\end{array}$ & $\begin{array}{l}\text { State and } \\
\text { trait anxi- } \\
\text { ety during } \\
\text { preg- } \\
\text { nancy }\end{array}$ \\
\hline (13) & $\begin{array}{l}\text { Larsson (in } \\
\text { press) }\end{array}$ & $\begin{array}{l}\text { Sweden } \\
\text { 2014- } 2015 \\
\text { RCT } \\
\text { weak }\end{array}$ & $\begin{array}{l}N=258 \\
\text { Age }(\mathrm{n}, \%) \\
<25: 14(10.4) \\
\text { 25-35: } 100 \\
(74.6) \\
>35: 20(14.9) \\
\text { Primi- or/and } \\
\text { multiparous } \\
\text { could not be } \\
\text { stated }\end{array}$ & $\begin{array}{l}\text { IG: internet- } \\
\text { based cognitive } \\
\text { behavioral ther- } \\
\text { apy (iCBT) } \\
\text { CG: standard } \\
\text { care (i.e. coun- } \\
\text { seling with mid- } \\
\text { wives) }\end{array}$ & $\begin{array}{l}\text { No statistically significant difference in the } \\
\text { perceptions of the birth experience, re- } \\
\text { gardless of treatment method for fear of } \\
\text { birth. }\end{array}$ & $\begin{array}{l}\text { Fear of birth } \\
\text { scale }\end{array}$ & FOC \\
\hline (14) & $\begin{array}{l}\text { Swift (in } \\
\text { press) }\end{array}$ & $\begin{array}{l}\text { Iceland } \\
2017-2018\end{array}$ & $\begin{array}{l}N=92 \\
\text { Age: } \\
\text { IG: } 28.3(5.1)\end{array}$ & $\begin{array}{l}\text { IG: Enhanced } \\
\text { Antenatal Care } \\
\text { (EAC) }\end{array}$ & $\begin{array}{l}\text { At baseline, a higher proportion of IG par- } \\
\text { ticipants }(28 \%) \text { reported high fear }>60 \\
\text { points) compared with women in CG } \\
(21 \%) \text {. By T2 fewer women reported high }\end{array}$ & $\begin{array}{l}\text { Fear of birth } \\
\text { scale (FOBS) }\end{array}$ & FOC \\
\hline
\end{tabular}




\begin{tabular}{|c|c|c|c|c|c|c|c|}
\hline & & $\begin{array}{l}\text { quasi-experi- } \\
\text { mental control- } \\
\text { led trial } \\
\text { strong }\end{array}$ & $\begin{array}{l}\text { CG: } 27.9(4.4) \\
\text { Primiparous }\end{array}$ & $\begin{array}{l}\text { CG: usual ante- } \\
\text { natal care }\end{array}$ & $\begin{array}{l}\text { fear of birth in IG }(9.4 \%) \text { compared with CG } \\
(15.0 \%) \text {. } \\
\text { For the full sample, the mean childbirth fear } \\
\text { change score was } 7.2 \text { points among } \\
\text { women in IG and }-3.0 \text { points among } \\
\text { women in usual care } p=0.315) \text {. Based on } \\
\text { Cohen's criteria the effect of participating } \\
\text { in IG on the reduction in mean childbirth } \\
\text { fear was small (Cohen's } d=0.21) \text {. Restrict- } \\
\text { ing the main analysis to women who had } \\
\text { not attended classes alongside antenatal } \\
\text { care ( } n=26) \text { resulted in a large effect size } \\
\text { difference in fear change between women } \\
\text { in IG and CG (Cohen's d=-0.83), with a } \\
\text { change score of }-14.1 \text { points among } \\
\text { women in IG and a slight increase in fear } \\
\text { among women in CG ( } 1.2 \text { points; } p=.003) \text {. }\end{array}$ & & \\
\hline (15) & $\begin{array}{l}\text { Shahsavan } \\
(2020)\end{array}$ & $\begin{array}{l}\text { Iran } \\
2018 \\
\text { quasi-experi- } \\
\text { mental study } \\
\text { strong }\end{array}$ & $\begin{array}{l}N=102 \\
\text { Age: } \\
\text { IG: } 28.10( \pm \\
5.20) \\
\text { CG: } 28.69( \pm \\
5.31) \\
\text { Primiparous }\end{array}$ & $\begin{array}{l}\text { IG: Internet- } \\
\text { based guided } \\
\text { self-help cogni- } \\
\text { tive- behavioral } \\
\text { therapy } \\
\text { (I-GSH-CBT) } \\
\text { CG: normal } \\
\text { pregnancy care }\end{array}$ & $\begin{array}{l}\text { The IG intervention could significantly re- } \\
\text { duce the scores of childbirth fear }(p=.002) \text {. } \\
\text { The fear scores in the control group were } \\
\text { significantly increased in parallel with the I- } \\
\text { GSH-CBT intervention }(p<.001) \text {. }\end{array}$ & W-DEQ & FOC \\
\hline (16) & Boz (2020) & $\begin{array}{l}\text { Turkey } \\
2018 \\
\text { RCT } \\
\text { moderate }\end{array}$ & $\begin{array}{l}N=24 \\
\text { Age: } \\
28.21( \pm 4.37) \\
\text { Primiparous }\end{array}$ & $\begin{array}{l}\text { IG: Psychoedu- } \\
\text { cation Program } \\
\text { based on Hu- } \\
\text { man Caring } \\
\text { Theory in The } \\
\text { Management of } \\
\text { Fear of Child- } \\
\text { birth } \\
\text { CG: Antenatal } \\
\text { education clas- } \\
\text { ses group }\end{array}$ & $\begin{array}{l}\text { The FOC of women from pretest to posttest } \\
\text { was statistically more reduced in the psy- } \\
\text { choeducation group compared to the ante- } \\
\text { natal education group }(p=.000) \text {. }\end{array}$ & W-DEQ-A/B & FOC \\
\hline
\end{tabular}




\begin{tabular}{|c|c|c|c|c|c|c|c|}
\hline (17) & $\begin{array}{l}\text { Abdollahi } \\
(2020)\end{array}$ & $\begin{array}{l}\text { Iran } \\
2018 \\
\text { RCT } \\
\text { moderate }\end{array}$ & $\begin{array}{l}N=70 \\
\text { Age (range): } \\
\text { aged 18-50 } \\
\text { Primi- and } \\
\text { Multiparous }\end{array}$ & $\begin{array}{l}\text { IG: Motivational } \\
\text { Interviewing (MI) } \\
\text { Psychotherapy } \\
\text { CG: Prenatal } \\
\text { usual care } \\
\text { (PUC) }\end{array}$ & $\begin{array}{l}\text { The total score of W-DEQ declined more } \\
\text { considerably in the IG than in the CG be- } \\
\text { tween pre-trial (T0) and post-trial (T1), with } \\
\text { a large effect size }\left(B=-23.54, p<.001, \eta^{2}=\right. \\
0.27) \text {. Scores of the six subscales of W- } \\
\text { DEQ diminished more substantially in psy- } \\
\text { chotherapy than in prenatal usual care. }\end{array}$ & $\begin{array}{l}\text { W-DEQ } \\
\text { Spielberger } \\
\text { state anxiety }\end{array}$ & FOC \\
\hline (18) & $\begin{array}{l}\text { Hamilton } \\
(2020)\end{array}$ & $\begin{array}{l}\text { UK } \\
\text { Date of data } \\
\text { collection } \\
\text { could not be } \\
\text { stated } \\
\text { RCT } \\
\text { weak }\end{array}$ & $\begin{array}{l}N=39 \\
\text { Age: } \\
\text { TAU+CAT: } \\
30.2(6.4) \\
\text { TAU: } 31(2.9) \\
\text { Not stated if } \\
\text { primi-and/or } \\
\text { multiparous }\end{array}$ & $\begin{array}{l}\text { IG: cognitive an- } \\
\text { alytic therapy } \\
\text { (CAT) plus treat- } \\
\text { ment as usual } \\
\text { (TAU) } \\
\text { CG: treatment } \\
\text { as usual (TAU) }\end{array}$ & $\begin{array}{l}\text { The analysis found no difference in the pri- } \\
\text { mary outcome. The STAl scale at } 24 \\
\text { weeks after randomization between the } \\
\text { groups, with an adjusted difference in } \\
\text { means of } 6.1 \text { points ( } 95 \% \mathrm{Cl}:-4.2 \text { to } 16.3 \text { ) } \\
\text { was in favor of CAT for the State domain } \\
\text { and } 6.2 \text { points (95\% Cl: }-2.8 \text { to 15.2) for } \\
\text { the Trait domain. } \\
\text { The CAT + TAU group having lower (bet- } \\
\text { ter) STAl scores at all four post-randomi- } \\
\text { zation assessment points than the TAU } \\
\text { group. } \\
\text { For the four post-randomization repeated } \\
\text { STAI measures, a simple summary meas- } \\
\text { ure for each individual patient, the average } \\
\text { post-randomization score was calculated. } \\
\text { Average post-randomization STAl scores } \\
\text { were compared between the two arms } \\
\text { (CAT and TAU), again with analyses unad- } \\
\text { justed and adjusted for covariates. All the } \\
\text { 95\% Cls for the difference in mean follow- } \\
\text { up scores between the CAT and TAU } \\
\text { groups, include zero, which is compatible } \\
\text { with no difference in outcomes between } \\
\text { the randomized groups. }\end{array}$ & $\begin{array}{l}\text { Spielberger } \\
\text { State/Trait Anxi- } \\
\text { ety Inventory } \\
\text { (STAI) }\end{array}$ & $\begin{array}{l}\text { State/ } \\
\text { Trait } \\
\text { Anxiety }\end{array}$ \\
\hline (19) & $\begin{array}{l}\text { Noorbala } \\
(2019)\end{array}$ & $\begin{array}{l}\text { Iran } \\
2015-2018\end{array}$ & $\begin{array}{l}N=202 \\
\text { Age: } \\
27.92 \pm 5.41\end{array}$ & $\begin{array}{l}\text { IG: life skills and } \\
\text { stress manage- } \\
\text { ment training, } \\
\text { supportive psy- }\end{array}$ & $\begin{array}{l}\text { In the investigation of mental health sub- } \\
\text { scales in the IGs and CGs, results demon- } \\
\text { strated a significant intergroup difference } \\
\text { in the } 35-37 \text { week follow-up in terms of }\end{array}$ & $\begin{array}{l}\text { General Health } \\
\text { Questionnaire- } \\
28 \text { (GHQ-28) }\end{array}$ & $\begin{array}{l}\text { Mental } \\
\text { health of } \\
\text { pregnant } \\
\text { women - } \\
\text { anxiety }\end{array}$ \\
\hline
\end{tabular}




\begin{tabular}{|c|c|c|c|c|c|c|c|}
\hline & & $\begin{array}{l}\text { Clinical Trial } \\
\text { Study } \\
\text { weak }\end{array}$ & $\begin{array}{l}\text { Primi- or/and } \\
\text { multiparous } \\
\text { not stated }\end{array}$ & $\begin{array}{l}\text { chotherapy, ed- } \\
\text { ucational pack- } \\
\text { age and drug } \\
\text { therapies } \\
\text { CG: routine } \\
\text { pregnancy treat- } \\
\text { ment }\end{array}$ & $\begin{array}{l}\text { anxiety }(p=.003) \text {. Anxiety showed a signifi- } \\
\text { cant decrease compared to the CG. }\end{array}$ & $\begin{array}{l}\text { Golombok Rust } \\
\text { Inventory of } \\
\text { Marital State } \\
\text { (GRIMS) }\end{array}$ & \\
\hline (20) & $\begin{array}{l}\text { Uludağ } \\
\text { (2020) }\end{array}$ & $\begin{array}{l}\text { Turkey } \\
\text { Date of data } \\
\text { collection } \\
\text { could not be } \\
\text { stated } \\
\text { RCT } \\
\text { moderate }\end{array}$ & $\begin{array}{l}N=60 \\
\text { Age: } \\
\text { IG: } 25.66 \pm \\
4.33 \\
\text { CG: } 24.70 \pm \\
4.75 \\
\text { Primiparous }\end{array}$ & $\begin{array}{l}\text { IG: Philosophy } \\
\text { of HypnoBirthing } \\
\text { CG: Routine } \\
\text { Care }\end{array}$ & $\begin{array}{l}\text { A statistically significant difference was } \\
\text { found between the labor fear mean score } \\
\text { in terms of group, time and group*time in- } \\
\text { teraction }(p<.05) \text {. There was a significant } \\
\text { difference between the post-intervention, } \\
\text { active phase and transition phase labor } \\
\text { fear mean score of the groups in terms of } \\
\text { the intervention performed: the fear of la- } \\
\text { bor was lower in the IG compared to the } \\
\text { CG. }\end{array}$ & $\begin{array}{l}\text { Visual analog } \\
\text { scale of deter- } \\
\text { mining the fear } \\
\text { and pain of la- } \\
\text { bor }\end{array}$ & Labor fear \\
\hline (21) & $\begin{array}{l}\text { Rajeswari } \\
(2020)\end{array}$ & $\begin{array}{l}\text { India } \\
2015-2016 \\
\text { RCT } \\
\text { moderate }\end{array}$ & $\begin{array}{l}N=250 \\
\text { Age: } \\
\text { Majority were } \\
\text { in the age } \\
\text { group of } 25- \\
29 \text { years (IG } \\
60[48 \%] ; \mathrm{CG} \\
57[45.60 \%]) \text {. } \\
\text { primiparous }\end{array}$ & $\begin{array}{l}\text { IG: Routine } \\
\text { Care + progres- } \\
\text { sive muscle re- } \\
\text { laxation } \\
\text { CG: routine an- } \\
\text { tenatal care }\end{array}$ & $\begin{array}{l}\text { In the posttest, the groups exhibited signif- } \\
\text { icant difference for stress }\left(F_{3}=24.81 \text {, }\right. \\
p<.001) \text { and overall anxiety }\left(F_{3}=19.80 \text { with }\right. \\
p<.001) \text {. After the test, there was a signifi- } \\
\text { cant reduction in state anxiety }\left(F_{3}=17.80 \text {, }\right. \\
p<.001) \text { and trait anxiety }\left(F_{3}=18.60 \text {, }\right. \\
p<.001) \text { between the intervention and con- } \\
\text { trol groups. } \\
\text { There was a strong negative correlation } \\
\text { between PMR and state anxiety }(r=-0.26 \text {, } \\
p<.001) \text {, }\end{array}$ & $\begin{array}{l}\text { State-Trait Anxi- } \\
\text { ety Inventory } \\
\text { (STAI) }\end{array}$ & $\begin{array}{l}\text { State/ } \\
\text { Trait } \\
\text { Preg- } \\
\text { nancy } \\
\text { anxiety }\end{array}$ \\
\hline (22) & $\begin{array}{l}\text { Bazrafsahn } \\
(2020)\end{array}$ & $\begin{array}{l}\text { Iran } \\
2019 \\
\text { RCT } \\
\text { strong }\end{array}$ & $\begin{array}{l}N=72 \\
\text { Age: } \\
\text { IG: } 28.06 \pm \\
4.33 \\
\text { CG: } 26.22 \pm \\
4.43\end{array}$ & $\begin{array}{l}\text { IG: group edu- } \\
\text { cational coun- } \\
\text { seling sessions } \\
\text { (integration of } \\
\text { psychological in- } \\
\text { structions and }\end{array}$ & $\begin{array}{l}\text { There was a significant difference in the } \\
\text { mean anxiety score between the IG and } \\
\text { CG before the group educational counsel- } \\
\text { ing sessions. After this intervention, a sig- } \\
\text { nificant reduction in the mean anxiety } \\
\text { scores of intervened pregnant women } \\
\text { compared to the control was found. This } \\
\text { decrease in mean anxiety score after the }\end{array}$ & $\begin{array}{l}\text { Pregnancy-re- } \\
\text { lated anxiety } \\
\text { questionnaire } \\
\text { Short-form } \\
\text { PRAQ with } 17 \\
\text { items (PRAQ- } \\
17 \text { ) }\end{array}$ & $\begin{array}{l}\text { Preg- } \\
\text { nancy re- } \\
\text { lated } \\
\text { anxiety }\end{array}$ \\
\hline
\end{tabular}




\begin{tabular}{|c|c|c|c|c|c|c|c|}
\hline & & & $\begin{array}{l}\text { Primi-and/or } \\
\text { Multiparous } \\
\text { could not be } \\
\text { stated }\end{array}$ & $\begin{array}{l}\text { interactive lec- } \\
\text { tures) + routine } \\
\text { care } \\
\text { CG: routine } \\
\text { pregnancy care }\end{array}$ & $\begin{array}{l}1 \text {-month post-counseling was more pro- } \\
\text { nounced than the } 6^{\text {th }} \text { week after the study } \\
\text { onset } p<.001) \text {. Low anxiety scores in the } \\
\text { intervention group over time were also } \\
\text { maintained. }\end{array}$ & & \\
\hline (23) & $\begin{array}{l}\text { Munkhon- } \\
\text { dya } \\
(2020)\end{array}$ & $\begin{array}{l}\text { Malawi } \\
2018 \\
\text { quasi-experi- } \\
\text { mental study } \\
\text { moderate }\end{array}$ & $\begin{array}{l}N=70 \\
\text { Age: } \\
\text { IG: } 19.83( \pm \\
2.90) \\
\text { CG: } 20.11( \pm \\
2.70) \\
\text { Primiparous }\end{array}$ & $\begin{array}{l}\text { IG: companion- } \\
\text { integrated child- } \\
\text { birth preparation } \\
\text { (structured } \\
\text { childbirth educa- } \\
\text { tion) } \\
\text { CG: Routine } \\
\text { care }\end{array}$ & $\begin{array}{l}\text { At post-test, being in the intervention group } \\
\text { significantly decreased childbirth fears }(\beta \text { := } \\
-.866, t(68)=-14.27, p<.001) \text {. }\end{array}$ & $\begin{array}{l}\text { Childbirth Atti- } \\
\text { tude Question- } \\
\text { naire (CAQ) }\end{array}$ & FOC \\
\hline (24) & $\begin{array}{l}\text { Price } \\
\text { (2019) }\end{array}$ & $\begin{array}{l}\text { USA } \\
\text { Date of data } \\
\text { collection } \\
\text { could not be } \\
\text { stated } \\
\text { one-group re- } \\
\text { peated } \\
\text { measures de- } \\
\text { sign } \\
\text { moderate }\end{array}$ & $\begin{array}{l}N=12 \\
\text { Age (median, } \\
\text { range): } 30.5 \\
(24-40) \\
\text { Primi- and } \\
\text { multiparous }\end{array}$ & $\begin{array}{l}\text { Mindfulness- } \\
\text { Based Childbirth } \\
\text { and Parenting } \\
\text { (MBCP) - online } \\
\text { audios }\end{array}$ & $\begin{array}{l}\text { The significant pre-post intervention im- } \\
\text { provements included a decrease in prena- } \\
\text { tal pregnancy anxiety }(p=.002) \text {, and in- } \\
\text { creased interoceptive awareness skills of } \\
\text { self-regulation }(p=.016) \\
\text { The significant longitudinal improvements } \\
\text { included interoceptive awareness skills of } \\
\text { self-regulation }(p=.04) \text {. The effect sizes for } \\
\text { these significant improvements were large, } \\
\text { ranging from } 0.62 \text { to } 1.18 \text {. }\end{array}$ & $\begin{array}{l}\text { Generalized } \\
\text { Anxiety Disorder } \\
\text { Scale (GAD-7) }\end{array}$ & $\begin{array}{l}\text { General } \\
\text { anxiety } \\
\text { during } \\
\text { preg- } \\
\text { nancy }\end{array}$ \\
\hline (25) & $\begin{array}{l}\text { Yang } \\
(2019)\end{array}$ & $\begin{array}{l}\text { China } \\
2018 \\
\text { RCT } \\
\text { strong }\end{array}$ & $\begin{array}{l}N=123 \\
\text { Age: } \\
\text { IG: } 31.31 \\
(4.97) \\
\text { CG: } 30.38 \\
(3.91)\end{array}$ & $\begin{array}{l}\text { IG: online mind- } \\
\text { fulness interven- } \\
\text { tion program } \\
\text { (training ac- } \\
\text { ceptance for in- } \\
\text { ternal and exter- } \\
\text { nal experiences) } \\
\text { CG: routine pre- } \\
\text { natal care }\end{array}$ & $\begin{array}{l}\text { In the IG, the mean scores of the PHQ-9 } \\
\text { and GAD-7 before the intervention indi- } \\
\text { cated mild symptoms of anxiety; these } \\
\text { scores decreased significantly at the end of } \\
\text { the intervention, indicating no symptoms } \\
(t=6.218, p<.001 ; t=5.422, p<.001 \text {, respec- } \\
\text { tively). No changes in the PHQ-9 and } \\
\text { GAD-7 scores were observed in women in } \\
\text { the CG when scores before versus after in- } \\
\text { tervention were compared. }\end{array}$ & $\begin{array}{l}\text { Generalized } \\
\text { Anxiety Disorder } \\
\text { Scale (GAD-7) }\end{array}$ & $\begin{array}{l}\text { General } \\
\text { Anxiety } \\
\text { during } \\
\text { preg- } \\
\text { nancy }\end{array}$ \\
\hline
\end{tabular}




\begin{tabular}{|c|c|c|c|c|c|c|c|}
\hline & & & $\begin{array}{l}\text { Primi- and } \\
\text { multiparous }\end{array}$ & & $\begin{array}{l}\text { Postintervention scores of both PHQ-9 and } \\
\text { GAD-7 were significantly lower in the IG } \\
\text { than in the CG. Additionally, a larger pro- } \\
\text { portion of women in the IG had no symp- } \\
\text { toms of anxiety after the IG compared with } \\
\text { women in the CG. }\end{array}$ & & \\
\hline (26) & $\begin{array}{l}\text { Van der } \\
\text { Zwan } \\
(2019)\end{array}$ & $\begin{array}{l}\text { Netherlands } \\
\text { Date of data } \\
\text { collection } \\
\text { could not be } \\
\text { stated } \\
\text { RCT } \\
\text { weak }\end{array}$ & $\begin{array}{l}\text { N=50 } \\
\text { Age: } 31.6(5.9) \\
\text { Primi- and } \\
\text { Multiparous }\end{array}$ & $\begin{array}{l}\text { IG: heart rate } \\
\text { variability } \\
\text { (HRV)-biofeed- } \\
\text { back + Stress- } \\
\text { Reducing Inter- } \\
\text { vention (psy- } \\
\text { choeducation + } \\
\text { taught ab- } \\
\text { dominal breath- } \\
\text { ing and HRV bi- } \\
\text { ofeedback) } \\
\text { CG: Waitlist } \\
\text { condition }\end{array}$ & $\begin{array}{l}\text { In both conditions anxiety and stress levels } \\
\text { were reduced and well-being increased } \\
\text { between pre- and post-test (T1-T2). In the } \\
\text { HRV-biofeedback condition, within-group } \\
\text { effect sizes were medium, and long-term } \\
\text { improvements six weeks after the training } \\
\text { (T1-T3) were similar to those at post-test } \\
\text { for all outcome measures except depres- } \\
\text { sion. Statistically significant long-term im- } \\
\text { provements in the HRV-biofeedback con- } \\
\text { dition were present for stress and psycho- } \\
\text { logical well-being. } \\
\text { Effect sizes were larger in the HRV-bio- } \\
\text { feedback condition than in the waitlist con- } \\
\text { dition on all outcome variables except anx- } \\
\text { iety. } \\
\text { When comparing the treatment effect be- } \\
\text { tween pregnant and non-pregnant women } \\
\text { (the Condition-Pregnancy interaction), a } \\
\text { statistically significant interaction effect for } \\
\text { anxiety appeared. Additional analyses } \\
\text { showed that HRV-biofeedback was more } \\
\text { beneficial regarding anxiety reduction for } \\
\text { pregnant women than for non-pregnant } \\
\text { women (pregnant women: } B=-4.18 \text {, } \\
t=-2.74 \text {, } p=.006 \text {; non-pregnant women: } \\
B=2.55, t=1.99, p=.046 \text { ). }\end{array}$ & $\begin{array}{l}\text { Dutch version of } \\
\text { the Depression } \\
\text { Anxiety Stress } \\
\text { Scales (DASS) }\end{array}$ & $\begin{array}{l}\text { Anxiety } \\
\text { during } \\
\text { preg- } \\
\text { nancy }\end{array}$ \\
\hline (27) & $\begin{array}{l}\text { Loughnan } \\
(2019)\end{array}$ & $\begin{array}{l}\text { Australia } \\
\text { Date of data } \\
\text { collection } \\
\text { could not be } \\
\text { stated }\end{array}$ & $\begin{array}{l}N=77 \\
\text { Age: } 31.61 \\
(4.00)\end{array}$ & $\begin{array}{l}\text { IG: internet-de- } \\
\text { livered cognitive } \\
\text { behavioral ther- } \\
\text { apy }\end{array}$ & $\begin{array}{l}\text { The group by time interactions for psycho- } \\
\text { logical distress }(F(2,53.93)=7.07, p<.01) \\
\text { and anxiety }(F(2,54.67)=6.48, p<.01) \\
\text { were significant. Participants in the IG } \\
\text { demonstrated large and superior reduc- }\end{array}$ & $\begin{array}{l}\text { Generalized } \\
\text { Anxiety Disorder } \\
\text { 7-item scale } \\
\text { (GAD-7) }\end{array}$ & $\begin{array}{l}\text { General } \\
\text { Anxiety } \\
\text { during } \\
\text { preg- } \\
\text { nancy }\end{array}$ \\
\hline
\end{tabular}




\begin{tabular}{|c|c|c|c|c|c|c|c|}
\hline & & $\begin{array}{l}\text { RCT } \\
\text { weak }\end{array}$ & $\begin{array}{l}\text { Primi - \& Multi- } \\
\text { parous }\end{array}$ & $\begin{array}{l}\text { CG: treatment } \\
\text { as usual (TAU) }\end{array}$ & $\begin{array}{l}\text { tions in distress at post-assessment com- } \\
\text { pared to CG }(g(95 \% \mathrm{Cl})=0.88(0.34,1.43)) \text {, } \\
\text { and moderate differences at follow-up, alt- } \\
\text { hough these were not statistically signifi- } \\
\text { cant }(g(95 \% \mathrm{Cl})=0.52(-0.07,1.10)) \text {. The } \\
\text { between group differences for anxiety se- } \\
\text { verity were small and non-significant post- } \\
\text { assessment }(g(95 \% \mathrm{Cl})=0.40(-0.13,0.93)) \text {. } \\
\text { However, IG demonstrated a moderate to } \\
\text { large effect size reduction in anxiety symp- } \\
\text { tom severity at follow-up assessment com- } \\
\text { pared to the CG }(g=0.76 ; \quad 95 \% \\
\mathrm{Cl}: 0.17,1.35) \text {. }\end{array}$ & & \\
\hline (28) & $\begin{array}{l}\text { Zemestani } \\
(2019)\end{array}$ & $\begin{array}{l}\text { Iran } \\
\text { Date of data } \\
\text { collection } \\
\text { could not be } \\
\text { stated } \\
\text { RCT } \\
\text { strong }\end{array}$ & $\begin{array}{l}N=38 \\
\text { Age: } \\
\text { IG: } 28.63 \\
(3.02) \\
\text { CG: } 30.54 \\
(4.15) \\
\text { Primi- and } \\
\text { multiparous }\end{array}$ & $\begin{array}{l}\text { IG: Mindfulness- } \\
\text { based cognitive } \\
\text { therapy (MBCT) } \\
\text { intervention } \\
\text { CG: Did not re- } \\
\text { ceive any inter- } \\
\text { vention; after 1- } \\
\text { month follow-up, } \\
\text { two psychoedu- } \\
\text { cational ses- } \\
\text { sions were con- } \\
\text { ducted }\end{array}$ & $\begin{array}{l}\text { Results from the mixed method repeated } \\
\text { measure (MMRM) indicate greater im- } \\
\text { provements in levels of anxiety in the IG } \\
\text { than in the CG. } \\
\text { As to BAI, results indicated a significant ef- } \\
\text { fect of time, } \mathrm{F}=(43.72), p<.0001, \mathrm{np}^{2}=.62 \text {; } \\
\text { and a significant timexgroup interaction, } \\
\mathrm{F}=(52.68), p<.0001, \mathrm{np}^{2}=.67 \text {. Post hoc } \\
\text { comparisons showed that the IG had a sig- } \\
\text { nificant decrease in BAI scores from base- } \\
\text { line to post-treatment and BAI scores re- } \\
\text { mained significantly lower than those of the } \\
\mathrm{CG} \text { at follow-up }(p<.0001) \text {. }\end{array}$ & $\begin{array}{l}\text { Beck Anxiety In- } \\
\text { ventory (BAI) }\end{array}$ & $\begin{array}{l}\text { Anxiety } \\
\text { during } \\
\text { preg- } \\
\text { nancy }\end{array}$ \\
\hline (29) & $\begin{array}{l}\text { Amiri } \\
(2019)\end{array}$ & $\begin{array}{l}\text { Iran } \\
2018 \\
\text { RCT } \\
\text { strong }\end{array}$ & $\begin{array}{l}N=68 \\
\text { Age: } \\
\text { IG: } \\
26.2(5.4) \\
\text { CG: } \\
27.0(5.6) \\
\text { Primi-and Mul- } \\
\text { tiparous }\end{array}$ & $\begin{array}{l}\text { IG: Counseling } \\
\text { based on dis- } \\
\text { traction tech- } \\
\text { niques for con- } \\
\text { trolling stress, } \\
\text { fear and pain } \\
\text { CG: training } \\
\text { about signs and } \\
\text { stages of deliv- } \\
\text { ery and the ap- } \\
\text { propriate time }\end{array}$ & $\begin{array}{l}\text { There was no statistically significant differ- } \\
\text { ence between the two groups before the in- } \\
\text { tervention }(p=.117) \text {. But in the } 36 \text { th week of } \\
\text { pregnancy the mean score of the fear of } \\
\text { childbirth in the IG was less than that of the } \\
\text { CG, but the difference was not statistically } \\
\text { significant (AMD: } 5.4 ; 95 \% \mathrm{Cl}:-2.4 \text { to } 13.0 \text {; } \\
p=.117) \text {. There was no statistically signifi- } \\
\text { cant difference between the groups after } \\
\text { intervention }(p=.170) \text {. }\end{array}$ & W-DEQ-A & FOC \\
\hline
\end{tabular}




\begin{tabular}{|c|c|c|c|c|c|c|c|}
\hline & & & & $\begin{array}{l}\text { for a referral to } \\
\text { the hospital }\end{array}$ & & & \\
\hline (30) & $\begin{array}{l}\text { Rahmani } \\
(2019)\end{array}$ & $\begin{array}{l}\text { Iran } \\
\text { Date of data } \\
\text { collection } \\
\text { could not be } \\
\text { stated } \\
\text { RCT } \\
\text { moderate }\end{array}$ & $\begin{array}{l}\mathrm{N}=108 \\
\text { Age (18-35): } \\
\text { IG 1: } 24.4 \\
(4.14) \\
\text { IG 2: } 26.52 \\
(4.6) \\
\text { CG: } 25.6 \\
\text { (4.35) } \\
\text { Primi- and } \\
\text { Multiparous }\end{array}$ & $\begin{array}{l}\text { IG 1: Peer Edu- } \\
\text { cation + training } \\
\text { booklet } \\
\text { IG 2: Discussion } \\
\text { Groups + train- } \\
\text { ing booklet } \\
\text { CG: not descri- } \\
\text { bed }\end{array}$ & $\begin{array}{l}\text { Significant difference among the } 3 \text { groups } \\
(p=.007) \text { after } 4 \text { weeks of intervention. } \\
\text { Further, the Scheffe test showed a } \\
\text { significant difference between the peer } \\
\text { education and control groups }(p=.04) \text {, as } \\
\text { well as the training and discussion groups } \\
\text { with the peer education group }(p=.013) \text {. }\end{array}$ & $\begin{array}{l}\text { Widget's } \\
\text { Maternity Fear } \\
\text { Awareness } \\
\text { Questionnaire }\end{array}$ & FOC \\
\hline (31) & $\begin{array}{l}\text { Zhang } \\
(2018)\end{array}$ & $\begin{array}{l}\text { China } \\
2016 \\
\text { RCT } \\
\text { moderate }\end{array}$ & $\begin{array}{l}\text { N=66 } \\
\text { Age: } \\
\text { IG: } 25.7(2.79) \\
\text { CG: } \\
25.58(2.33) \\
\text { Primi- and } \\
\text { multiparous }\end{array}$ & $\begin{array}{l}\text { IG: Mindfulness } \\
\text { stress reduction } \\
\text { (MBSR) } \\
\text { CG: treatment- } \\
\text { as-usual }\end{array}$ & $\begin{array}{l}\text { The results found a significant interaction } \\
\text { between time and condition for anxiety } \\
\left(F=19.30, p<.001, \eta^{2}=0.240\right) \text {. } \\
\text { Post hoc comparisons showed that the } \\
\text { mindfulness stress reduction had a } \\
\text { stronger decrease in STAl from baseline to } \\
\text { post-treatment compared to the CG. }\end{array}$ & $\begin{array}{l}\text { State Trait Anxi- } \\
\text { ety Inventory } \\
\text { (STAI) }\end{array}$ & $\begin{array}{l}\text { State/ } \\
\text { Trait Anxi- } \\
\text { ety during } \\
\text { preg- } \\
\text { nancy }\end{array}$ \\
\hline (32) & $\begin{array}{l}\text { Hildingsson } \\
(2019)\end{array}$ & $\begin{array}{l}\text { Sweden } \\
2016-2017 \\
\text { Experimental } \\
\text { Study } \\
\text { strong }\end{array}$ & $\begin{array}{l}N=70 \\
\text { Age: } \\
<32: 29(41.4) \\
\geq 32: 41(58.6) \\
\text { Primiparous }\end{array}$ & $\begin{array}{l}\text { IG: Counseling } \\
\text { through known } \\
\text { midwives } \\
\text { CG: Counseling } \\
\text { through un- } \\
\text { known midwives }\end{array}$ & $\begin{array}{l}\text { No differences on level of fear in IG (mean } \\
\text { FOBS } 71.25 ; 20.41) \text { versus CG }(70.83 \text {; } \\
21.52) \text {. }\end{array}$ & $\begin{array}{l}\text { Fear of Birth } \\
\text { Scale (FOBS) }\end{array}$ & FOC \\
\hline (33) & $\begin{array}{l}\text { Klabbers } \\
(2019)\end{array}$ & $\begin{array}{l}\text { Netherlands } \\
\text { 2012-2015 } \\
\text { RCT } \\
\text { weak }\end{array}$ & $\begin{array}{l}N=134 \\
\text { Age: } \\
\text { IG 1: } 32.8(\mathrm{SD} \\
4.6) \\
\text { IG 2: } 31.8(\mathrm{SD} \\
3.9)\end{array}$ & $\begin{array}{l}\text { IG 1: Hap- } \\
\text { totherapy }(\mathrm{HT}) \\
\text { IG 2: Psycho- } \\
\text { education via } \\
\text { the Internet } \\
\text { (INT) }\end{array}$ & $\begin{array}{l}\text { In the intention to treat analysis, only the } \\
\text { IG } 1 \text { showed a significant decrease of fear } \\
\text { of childbirth, } F(2,99)=.321, p=.040 \text {. In the } \\
\text { as treated analysis, the IG } 1 \text { showed a } \\
\text { greater reduction in fear of childbirth than } \\
\text { the other two groups, } F(3,83)=6.717 \text {, } \\
p<.001 \text {. }\end{array}$ & W-DEQ & $\mathrm{FOC}$ \\
\hline
\end{tabular}




\begin{tabular}{|c|c|c|c|c|c|c|c|}
\hline & & & $\begin{array}{l}\text { CG: } \\
32.6 \text { (SD 5.3) } \\
\text { Primi-and Mul- } \\
\text { tiparous }\end{array}$ & $\begin{array}{l}\text { CG: Care as } \\
\text { usual (CAU) }\end{array}$ & & & \\
\hline (34) & $\begin{array}{l}\text { Irmak } \\
\text { (2019) }\end{array}$ & $\begin{array}{l}\text { Turkey } \\
\text { 2016- } 2017 \\
\text { RCT } \\
\text { strong }\end{array}$ & $\begin{array}{l}N=120 \\
\text { Age: } \\
\text { IG 1: } 27.29 \pm \\
3.97 \\
\text { IG 2: } 27.51 \pm \\
4.65 \\
\text { CG: } 27.36 \pm \\
4.19 \\
\text { Primiparous }\end{array}$ & $\begin{array}{l}\text { IG 1: } \\
\text { Emotional free- } \\
\text { dom techniques } \\
\text { (EFT) } \\
\text { IG 2: } \\
\text { breathing awa- } \\
\text { reness (BA) } \\
\text { CG: Standard } \\
\text { care. }\end{array}$ & 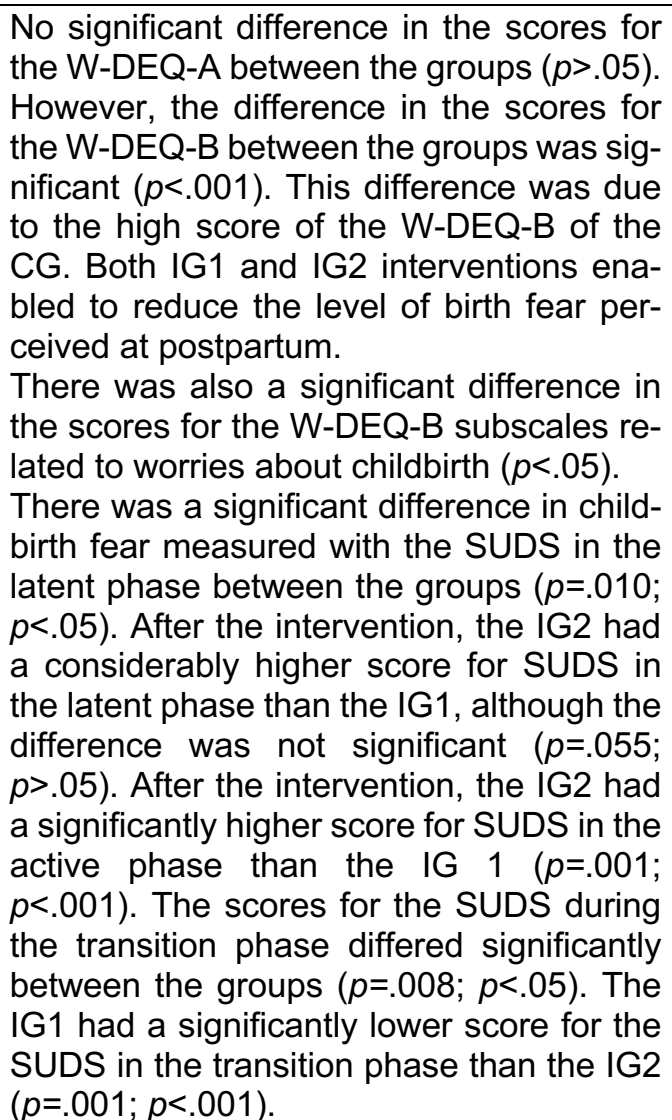 & $\begin{array}{l}\text { W-DEQ } \\
\text { Subjective Units } \\
\text { of Distress } \\
\text { Scale (SUDS) }\end{array}$ & FOC \\
\hline (35) & $\begin{array}{l}\text { Heller } \\
(2020)\end{array}$ & $\begin{array}{l}\text { Netherlands } \\
\text { Date of data } \\
\text { collection } \\
\text { could not be } \\
\text { stated }\end{array}$ & $\begin{array}{l}N=79 \\
\text { IG: } 32.08 \\
(4.61) \\
\text { CG: } 31.94 \\
(4.83)\end{array}$ & $\begin{array}{l}\text { IG: internet- } \\
\text { based problem } \\
\text { solving treat- } \\
\text { ment } \\
\text { (PST) }\end{array}$ & $\begin{array}{l}\text { In the IG, affective symptoms decreased } \\
\text { more than that in the CG, but between- } \\
\text { group effect sizes were small to medium } \\
\text { (Cohen's d at T3=0.45, } 0.21 \text {, and } 0.23 \text { for } \\
\text { the } 3 \text { questionnaires, respectively) and sta- } \\
\text { tistically not significant. }\end{array}$ & $\begin{array}{l}\text { Hospital Anxiety } \\
\text { and Depression } \\
\text { Scale-Anxiety } \\
\text { subscale } \\
\text { (HADS-A) }\end{array}$ & $\begin{array}{l}\text { Anxiety } \\
\text { during } \\
\text { preg- } \\
\text { nancy }\end{array}$ \\
\hline
\end{tabular}




\begin{tabular}{|c|c|c|c|c|c|c|c|}
\hline & & $\begin{array}{l}\text { RCT } \\
\text { moderate }\end{array}$ & $\begin{array}{l}\text { Primi- and } \\
\text { Multiparous }\end{array}$ & $\begin{array}{l}\text { CG: Care as } \\
\text { usual }\end{array}$ & & & \\
\hline (36) & $\begin{array}{l}\text { Mohamm- } \\
\text { adi (2019) }\end{array}$ & $\begin{array}{l}\text { Iran } \\
2018 \\
\text { RCT } \\
\text { moderate }\end{array}$ & $\begin{array}{l}N=60 \\
\text { Age: } \\
\text { IG:28.18 } \pm 3.38 \\
\text { CG: } \\
28.63 \pm 3.14 \\
\text { Primi- and } \\
\text { multiparous }\end{array}$ & $\begin{array}{l}\text { IG: Intervention } \\
\text { group attended } \\
\text { Benson's re- } \\
\text { laxation techni- } \\
\text { que } \\
\text { (BRT) and brief } \\
\text { psychoeducatio- } \\
\text { nal intervention } \\
\text { (BPI) educatio- } \\
\text { nal sessions } \\
\text { CG: Received } \\
\text { no intervention }\end{array}$ & $\begin{array}{l}\text { Significant statistical difference in the IG } \\
\text { before and after intervention }(p<.001) \text {. In } \\
\text { the IG, the mean stress and anxiety } \\
\text { scores, and total score were decreased } \\
\text { significantly }(p<.001) \text {. The } C G \text { did not show } \\
\text { any significant statistical differences }(p> \\
.05) \text {. There was a significant difference } \\
\text { between the mean scores of IG and CG } \\
(p<.001) \text {. }\end{array}$ & $\begin{array}{l}\text { Depression } \\
\text { Anxiety Stress } \\
\text { Scale-21 }\end{array}$ & $\begin{array}{l}\text { Anxiety } \\
\text { during } \\
\text { preg- } \\
\text { nancy }\end{array}$ \\
\hline (37) & $\begin{array}{l}\text { Ekrami } \\
(2019)\end{array}$ & $\begin{array}{l}\text { Iran } \\
2017 \\
\text { RCT } \\
\text { strong }\end{array}$ & $\begin{array}{l}N=80 \\
\text { Age: } \\
\text { IG: } 28.5(7.4) \\
\text { CG: } 30.7(5.4) \\
\text { Primiparous }\end{array}$ & $\begin{array}{l}\text { IG: sessions of } \\
\text { individual coun- } \\
\text { seling + ses- } \\
\text { sions of group } \\
\text { counseling } \\
\text { CG: received } \\
\text { routine care }\end{array}$ & $\begin{array}{l}\text { The mean (SD) state anxiety score in the } \\
\text { IG decreased from before intervention to } 4 \\
\text { weeks after counseling; the mean (SD) } \\
\text { state anxiety score in the CG increased } \\
\text { from before the intervention to } 4 \text { weeks af- } \\
\text { ter the completion of the counseling. No } \\
\text { significant difference between the IG and } \\
\text { CG before the intervention in terms of state } \\
\text { anxiety score ( } p=.759) \text {. } \\
\text { The mean state anxiety score in the IG was } \\
\text { significantly lower than on the CG (ad- } \\
\text { justed mean difference: }-7.8 \text {, CI } 95 \%-4.5 \\
\text { to }-11.1 ; p<.001) \text { after intervention. } \\
\text { The mean (SD) trait anxiety score in the IG } \\
\text { decreased from before counseling to } 4 \\
\text { weeks after counseling; the mean (SD) trait } \\
\text { anxiety score in the IG was increased from } \\
\text { before the intervention to } 4 \text { weeks after the } \\
\text { completion of the counseling. There was } \\
\text { no significant difference between the IG } \\
\text { and CG before the intervention in terms of } \\
\text { trait anxiety score }(p=.473) \text {. The mean trait }\end{array}$ & $\begin{array}{l}\text { Spielberger } \\
\text { State-Trait Anxi- } \\
\text { ety Inventory } \\
\text { (STAI) }\end{array}$ & $\begin{array}{l}\text { State/ } \\
\text { Trait Anxi- } \\
\text { ety of } \\
\text { women } \\
\text { with un- } \\
\text { planned } \\
\text { preg- } \\
\text { nancy }\end{array}$ \\
\hline
\end{tabular}




\begin{tabular}{|c|c|c|c|c|c|c|c|}
\hline & & & & & $\begin{array}{l}\text { anxiety score in the IG was significantly } \\
\text { lower than on the CG (adjusted mean dif- } \\
\text { ference: }-8.2, \mathrm{Cl} 95 \%-10.9 \text { to }-5.4 \text {; } \\
p<.001 \text { ) after intervention. }\end{array}$ & & \\
\hline (38) & $\begin{array}{l}\text { Sobhani } \\
(2019)\end{array}$ & $\begin{array}{l}\text { Iran } \\
2017 \\
\text { RCT } \\
\text { weak }\end{array}$ & $\begin{array}{l}N=40 \\
\text { Age could not } \\
\text { be stated. } \\
\text { Primi- or/and } \\
\text { multiparous } \\
\text { not stated }\end{array}$ & $\begin{array}{l}\text { IG: Mindfulness } \\
\text { Based Stress } \\
\text { Reduction } \\
\text { (MBSR) } \\
\text { CG: unclear }\end{array}$ & $\begin{array}{l}\text { Mindfulness training had a significant ef- } \\
\text { fect on reducing anxiety and stress. }\end{array}$ & $\begin{array}{l}\text { Depression Anx- } \\
\text { iety Stress } \\
\text { Scale (DASS- } \\
\text { 21) }\end{array}$ & $\begin{array}{l}\text { Anxiety } \\
\text { during } \\
\text { preg- } \\
\text { nancy }\end{array}$ \\
\hline (39) & $\begin{array}{l}\text { Kacperczyk } \\
\text {-Bartnik } \\
(2019)\end{array}$ & $\begin{array}{l}\text { Poland } \\
2016 \\
\text { cross-sectional } \\
\text { survey-based } \\
\text { study } \\
\text { moderate }\end{array}$ & $\begin{array}{l}N=147 \\
\text { Age: } \\
31.5( \pm 4.8) \\
\text { Primi- and } \\
\text { Multiparous }\end{array}$ & $\begin{array}{l}\text { IG: Antenatal } \\
\text { classes atten- } \\
\text { dance } \\
\text { CG: No antena- } \\
\text { tal classes at- } \\
\text { tendance }\end{array}$ & $\begin{array}{l}\text { Women who gave birth for the first time } \\
\text { and attended antenatal classes scored sig- } \\
\text { nificantly lower in the DFS questionnaire } \\
(p<.03) \text {. } \\
\text { No significant differences in the DFS score } \\
\text { were observed in case of patients giving } \\
\text { birth for the second or subsequent time. } \\
\text { Respondents in the IG scored slightly } \\
\text { lower in comparison to the CG }(p<.90) \text {. }\end{array}$ & $\begin{array}{l}\text { Delivery Fear } \\
\text { Scale (DFS) }\end{array}$ & FOC \\
\hline (40) & $\begin{array}{l}\text { Uçar } \\
\text { (2019) }\end{array}$ & $\begin{array}{l}\text { Turkey } \\
2012-2013 \\
\text { pretest-post- } \\
\text { test experi- } \\
\text { mental design } \\
\text { weak }\end{array}$ & $\begin{array}{l}N=111 \\
\text { Age: } \\
25.5 \text { (SD 4.2) } \\
\text { Primiparous }\end{array}$ & $\begin{array}{l}\text { IG: educational } \\
\text { program on cop- } \\
\text { ing with child- } \\
\text { birth fears } \\
\text { based on CBT } \\
\text { CG: did not re- } \\
\text { ceive any inter- } \\
\text { vention }\end{array}$ & $\begin{array}{l}\text { The post-education W-DEQ-A score was } \\
\text { significant higher in the CG compared to } \\
\text { the IG }(p<.000) \text {. } \\
\text { No statistically significant difference was } \\
\text { found between the anxiety levels of the IG } \\
\text { and CG during the active phase of labor, } \\
\text { according to the sum of SAl scores } \\
(p=.533) \text {. }\end{array}$ & $\begin{array}{l}\text { State Anxiety In- } \\
\text { ventory (SAI) } \\
\text { W-DEQ-A }\end{array}$ & $\begin{array}{l}\text { FOC } \\
\text { State anx- } \\
\text { iety dur- } \\
\text { ing preg- } \\
\text { nancy }\end{array}$ \\
\hline (41) & $\begin{array}{l}\text { Narita } \\
(2018)\end{array}$ & $\begin{array}{l}\text { Japan } \\
\text { Date of data } \\
\text { collection } \\
\text { could not be } \\
\text { stated }\end{array}$ & $\begin{array}{l}N=97 \\
\text { Age: } \\
\text { IG: } 32.4( \pm 3.8) \\
\text { CG: } 32.7( \pm \\
5.0)\end{array}$ & $\begin{array}{l}\text { IG: heart rate } \\
\text { variability (HRV) } \\
\text { biofeedback In- } \\
\text { tervention } \\
\text { (Stress Eraser) }\end{array}$ & $\begin{array}{l}\text { The W-DEQ scores reduced significantly in } \\
\text { women who performed HRV biofeedback } \\
(n=18, p<.001) \text {, but there was no change in } \\
\text { those who did not perform the method } \\
(n=20) \text {. }\end{array}$ & W-DEQ-A & FOC \\
\hline
\end{tabular}




\begin{tabular}{|c|c|c|c|c|c|c|c|}
\hline & & $\begin{array}{l}\text { Experimental } \\
\text { Study } \\
\text { weak }\end{array}$ & $\begin{array}{l}\text { Primi- and } \\
\text { Multiparous }\end{array}$ & $\begin{array}{l}\text { CG: women did } \\
\text { not agree to } \\
\text { practice the } \\
\text { method }\end{array}$ & & & \\
\hline (42) & $\begin{array}{l}\text { Boryri } \\
(2018)\end{array}$ & $\begin{array}{l}\text { Iran } \\
2017 \\
\text { Quasi Experi- } \\
\text { mental Study } \\
\text { moderate }\end{array}$ & $\begin{array}{l}N=180 \\
\text { Age: } \\
24.54 \pm 4.40 \\
\text { Primiparous }\end{array}$ & $\begin{array}{l}\text { IG 1: muscle } \\
\text { relaxation } \\
\text { IG 2: guided } \\
\text { imagery } \\
\text { CG: Routine } \\
\text { care }\end{array}$ & $\begin{array}{l}\text { The scores of delivery fear before the } \\
\text { intervention significantly differed in the } \\
\text { three groups }(p=.01) \text {. A significant } \\
\text { difference was found between IG1 and IG2 } \\
(p=.01) \text {, while the other groups } \\
\text { represented no difference. However, the } \\
\text { mean score of the fear of delivery was } \\
\text { significant in the three groups after the } \\
\text { intervention ( } p=.0001) \text {. The post-hoc test } \\
\text { further indicated a statistically significant } \\
\text { difference in the mean scores of childbirth } \\
\text { fear between the IG1 and IG } 2 \text { ( } p=.0001) \text {, } \\
\text { IG1 and CG }(p=.0001) \text {, as well as IG } 2 \text { and } \\
\text { CG }(p=.0001) \text {. }\end{array}$ & $\begin{array}{l}\text { Brislin's } \\
\text { questionnaire }\end{array}$ & $\mathrm{FOC}$ \\
\hline (43) & $\begin{array}{l}\text { Warriner } \\
(2018)\end{array}$ & $\begin{array}{l}\text { UK } \\
\text { 2014-2015 } \\
\text { initial pilot } \\
\text { study } \\
\text { weak }\end{array}$ & $\begin{array}{l}N=155 \text { ( } 86 \text { wo- } \\
\text { men, } 69 \text { men) } \\
\text { Age (mean): } \\
35 \text { years } \\
\text { Primi- or/and } \\
\text { multiparous } \\
\text { could not be } \\
\text { stated }\end{array}$ & $\begin{array}{l}\text { IG: 'MBCP-4- } \\
\text { NHS' - Brief four } \\
\text { week course } \\
\text { (developed from } \\
\text { the nine week } \\
\text { Mindfulness } \\
\text { Based Childbirth } \\
\text { and Parenting } \\
\text { (MBCP) inter- } \\
\text { vention) }\end{array}$ & $\begin{array}{l}\text { Change in mood pre-to post course } \\
\text { showed that all scores improved and were } \\
\text { statistically significant for prospective } \\
\text { mothers, except for positive pregnancy ex- } \\
\text { perience intensity. Anxiety score has re- } \\
\text { duced to the 'mild' cut-off. }\end{array}$ & $\begin{array}{l}\text { Generalized } \\
\text { Anxiety Disorder } \\
\text { Scale (GAD-7) } \\
\text { Oxford Worries } \\
\text { about Labor } \\
\text { Scale (OWLS) } \\
\text { Pregnancy Ex- } \\
\text { perience Scale } \\
\text { (PES) } \\
\text { Brief Tilbury } \\
\text { Pregnancy Dis- } \\
\text { tress Scale } \\
\text { (TPDS) }\end{array}$ & $\begin{array}{l}\text { General } \\
\text { anxiety } \\
\text { during } \\
\text { preg- } \\
\text { nancy } \\
\text { Worries } \\
\text { about la- } \\
\text { bor } \\
\text { Preg- } \\
\text { nancy dis- } \\
\text { tress }\end{array}$ \\
\hline
\end{tabular}




\begin{tabular}{|c|c|c|c|c|c|c|c|}
\hline (44) & $\begin{array}{l}\text { Akbarian } \\
(2018)\end{array}$ & $\begin{array}{l}\text { Iran } \\
2016 \\
\text { RCT } \\
\text { weak }\end{array}$ & $\begin{array}{l}N=120 \\
\text { Age could not } \\
\text { be stated. } \\
\text { Primiparous }\end{array}$ & $\begin{array}{l}\text { IG: couples } \\
\text { (mental health } \\
\text { training course; } \\
\text { with the partner } \\
\text { present), preg- } \\
\text { nant women } \\
\text { (mental health } \\
\text { training course } \\
\text { without the part- } \\
\text { ner present) } \\
\text { CG: routine care }\end{array}$ & $\begin{array}{l}\text { In the pregnant women group and couples } \\
\text { group, the average anxiety score of preg- } \\
\text { nant women after the intervention was sig- } \\
\text { nificantly lower than before the intervention } \\
(p<.001) \text {. } \\
\text { A significant difference was shown among } \\
\text { the three groups after the intervention. Af- } \\
\text { ter the intervention, the mean anxiety score } \\
\text { of the pregnant women group was signifi- } \\
\text { cantly lower than that of the CG ( } p=.002) \\
\text { and this score was significantly lower in the } \\
\text { couples group than that in the pregnant } \\
\text { women group }(p=.045) \text {. }\end{array}$ & $\begin{array}{l}\text { Depression, } \\
\text { Anxiety, and } \\
\text { Stress Scales } \\
\text { (DASS-42) }\end{array}$ & $\begin{array}{l}\text { Anxiety } \\
\text { during } \\
\text { preg- } \\
\text { nancy }\end{array}$ \\
\hline (45) & $\begin{array}{l}\text { Krusche } \\
(2018)\end{array}$ & $\begin{array}{l}\text { UK } \\
\text { Date of data } \\
\text { collection } \\
\text { could not be } \\
\text { stated } \\
\text { RCT } \\
\text { moderate }\end{array}$ & $\begin{array}{l}N=185 \\
\text { Age (mean): } \\
32.7 \\
\text { Primi- and } \\
\text { multiparous }\end{array}$ & $\begin{array}{l}\text { IG: online mind- } \\
\text { fulness course } \\
\text { ('Be Mindful } \\
\text { Online') - imme- } \\
\text { diate } \\
\text { CG: waiting to } \\
\text { take the mindful- } \\
\text { ness course af- } \\
\text { ter the baby was } \\
\text { born }\end{array}$ & $\begin{array}{l}\text { A pairwise comparisons showed a de- } \\
\text { crease in anxiety for immediate, }[F(1,69)= \\
\left.18.42, p<.001), \eta^{2}=.21\right] \text { (mean difference - } \\
3.88 \text { ) and waitlist participants, }[F(1,69)= \\
\left.14.27, p<.001, \eta^{2}=.17\right] \text { (mean difference - } \\
2.23 \text { ). There was a trend for immediate } \\
\text { participants to have lower anxiety at T1 } \\
\text { compared to waitlist controls, }[F(1,69)= \\
\left.3.15, p=.08, \eta^{2}=.04\right] \text {. }\end{array}$ & $\begin{array}{l}\text { The General } \\
\text { Anxiety Disor- } \\
\text { der-7 (GAD-7 }\end{array}$ & $\begin{array}{l}\text { General } \\
\text { anxiety } \\
\text { during } \\
\text { preg- } \\
\text { nancy }\end{array}$ \\
\hline (46) & $\begin{array}{l}\text { Rondung } \\
(2018)\end{array}$ & $\begin{array}{l}\text { Sweden } \\
\text { 2014-2015 } \\
\text { RCT } \\
\text { moderate }\end{array}$ & $\begin{array}{l}N=258 \\
\text { Age: } \\
<25: 37(14.3) \\
\text { 25-35: } 186 \\
(72.1) \\
>35: 35(13.6) \\
\text { Primi- and } \\
\text { multiparous } \\
\text { women }\end{array}$ & $\begin{array}{l}\text { IG: Guided inter- } \\
\text { net-based on } \\
\text { cognitive behav- } \\
\text { ioral therapy } \\
\text { (ICBT) } \\
\text { CG: Standard } \\
\text { care group }\end{array}$ & $\begin{array}{l}\text { The reduction in FOB over time was signif- } \\
\text { icantly larger in the guided IG group than in } \\
\text { the CG group. However, the predicted level } \\
\text { of FOB at the estimated due date did not } \\
\text { differ significantly }(t 1,240.996=-0.24 \text {, } \\
p=.81) \text {. Hence, when comparing the inter- } \\
\text { vention groups, no difference was ob- } \\
\text { served in FOB in late pregnancy. }\end{array}$ & $\begin{array}{l}\text { Fear of Birth } \\
\text { Scale (FOBS) }\end{array}$ & FOC \\
\hline
\end{tabular}




\begin{tabular}{|c|c|c|c|c|c|c|c|}
\hline (47) & $\begin{array}{l}\text { Hajmoha- } \\
\text { madi } \\
(2018)\end{array}$ & $\begin{array}{l}\text { Iran } \\
2014 \\
\text { RCT } \\
\text { moderate }\end{array}$ & $\begin{array}{l}N=114 \\
\text { Age was not } \\
\text { stated } \\
\text { Not stated if } \\
\text { primi- or/and } \\
\text { multiparous }\end{array}$ & $\begin{array}{l}\text { IG: Psychoedu- } \\
\text { cation } \\
\text { CG: not stated }\end{array}$ & $\begin{array}{l}\text { The mean score of depression and anxiety } \\
\text { decreased significantly after the interven- } \\
\text { tion in comparison to that before the inter- } \\
\text { vention and that of CG }(p<.001) \text {. }\end{array}$ & $\begin{array}{l}\text { Researcher } \\
\text { made question- } \\
\text { naire based on } \\
\text { the Predispos- } \\
\text { ing, Reinforcing } \\
\text { and Enabling } \\
\text { Constructs in } \\
\text { Educational Di- } \\
\text { agnosis and } \\
\text { Evaluation }\end{array}$ & $\begin{array}{l}\text { Anxiety } \\
\text { during } \\
\text { preg- } \\
\text { nancy }\end{array}$ \\
\hline (48) & $\begin{array}{l}\text { Airo (Toiva- } \\
\text { nen) (2018) }\end{array}$ & $\begin{array}{l}\text { Finland } \\
2007-2010 \\
\text { Randomized } \\
\text { trial } \\
\text { weak }\end{array}$ & $\begin{array}{l}\mathrm{N}=460 \\
\text { Age: } \\
\text { IG: } 29.8( \pm 4.4) \\
\text { CG: } 28.3 \pm 5.0 \\
\text { Primiparous }\end{array}$ & $\begin{array}{l}\text { IG: group inter- } \\
\text { vention Nyytti® } \\
\text { (with psychedu- } \\
\text { cation elements, } \\
\text { the lifespan } \\
\text { model of motiva- } \\
\text { tion, practices to } \\
\text { support mentali- } \\
\text { sation and } \\
\text { mind-body con- } \\
\text { nection). }\end{array}$ & $\begin{array}{l}\text { FOC decreased statistically significantly } \\
\text { during the intervention from the baseline } \\
\text { (mean }=7.60, S D=1.72 \text { ) to the last session } \\
\text { before the childbirth (sixth session; } \\
\text { mean=4.56, } S D=2.42 \text {, Wald }=230.43, d f=6 \text {, } \\
p<.001 \text { ). }\end{array}$ & $\begin{array}{l}\text { W-DEQ-A } \\
\text { Visual Analog } \\
\text { Scale (VAS) to } \\
\text { measure subjec- } \\
\text { tive FOC }\end{array}$ & FOC \\
\hline (49) & $\begin{array}{l}\text { Duncan } \\
(2017)\end{array}$ & $\begin{array}{l}\text { USA } \\
\text { Date of data } \\
\text { collection } \\
\text { could not be } \\
\text { stated } \\
\text { RCT } \\
\text { moderate }\end{array}$ & $\begin{array}{l}N=30 \\
\text { Age could not } \\
\text { be stated } \\
\text { Primiparous }\end{array}$ & $\begin{array}{l}\text { IG: Short, time- } \\
\text { intensive } \\
\text { course. Mind in } \\
\text { Labor (MIL): } \\
\text { Working with } \\
\text { Pain in Child- } \\
\text { birth, based on } \\
\text { Mindfulness- } \\
\text { Based Childbirth } \\
\text { and Parenting } \\
\text { (MBCP) educa- } \\
\text { tion } \\
\text { CG: standard } \\
\text { childbirth prepa- } \\
\text { ration course }\end{array}$ & $\begin{array}{l}\text { Pain catastrophizing dropped by } 3.6 \text { points } \\
\text { in the IG group and was essentially un- } \\
\text { changed in the CG. The timegroup interac- } \\
\text { tion was not significant ( } \mathrm{t}=-1.06, p=.30 \text {; } \\
\text { estimated treatment effect }=-3.26 \text { points, } \\
80 \% \mathrm{Cl}[-7.3,0.8] \text { ). When the missing data } \\
\text { was imputed, the result did not change ( } \mathrm{t}= \\
-.71, p=.48) \text {. }\end{array}$ & $\begin{array}{l}\text { Pain Catastro- } \\
\text { phizing Scale } \\
\text { (PCS) }\end{array}$ & $\begin{array}{l}\text { Pain } \\
\text { catastro- } \\
\text { phizing }\end{array}$ \\
\hline
\end{tabular}




\begin{tabular}{|c|c|c|c|c|c|c|c|}
\hline & & & & $\begin{array}{l}\text { with no mind- } \\
\text { body focus }\end{array}$ & & & \\
\hline (50) & $\begin{array}{l}\text { Andaroon } \\
(2017)\end{array}$ & $\begin{array}{l}\text { Iran } \\
\text { 2015-2016 } \\
\text { RCT } \\
\text { moderate }\end{array}$ & $\begin{array}{l}N=93 \\
\text { Age could not } \\
\text { be stated } \\
\text { Primiparous } \\
\text { Women }\end{array}$ & $\begin{array}{l}\text { IG: face to face } \\
\text { individual coun- } \\
\text { seling } \\
\text { CG: } \\
\text { Usual services }\end{array}$ & $\begin{array}{l}\text { The present study showed that an individ- } \\
\text { ual counseling program provided by a mid- } \\
\text { wife based on a counseling consultant by a } \\
\text { midwife based on BELIFE counseling is ef- } \\
\text { fective in reducing fear of childbirth in a } \\
\text { way that the level of fear of childbirth in pri- } \\
\text { miparous women in the weeks } 36-34 \text { of } \\
\text { pregnancy in the IG was significantly lower } \\
\text { than the CG. }\end{array}$ & W-DEQ & FOC \\
\hline (51) & $\begin{array}{l}\text { Seyed Ka- } \\
\text { boli (2017) }\end{array}$ & $\begin{array}{l}\text { Iran } \\
2016 \\
\text { RCT } \\
\text { strong }\end{array}$ & $\begin{array}{l}\text { N=62 } \\
\text { Age: } \\
\text { 24-18: } \\
19(30.64) \\
29-25: \\
29(46.77) \\
35-30: \\
14(22.58) \\
\text { Primiparous }\end{array}$ & $\begin{array}{l}\text { IG: counseling } \\
\text { for } 6 \text { sessions of } \\
90 \text { minutes }+ \\
\text { routine prenatal } \\
\text { care } \\
\text { CG: routine pre- } \\
\text { natal care + in- } \\
\text { structional pack- } \\
\text { age for dealing } \\
\text { with pregnancy } \\
\text { stresses }\end{array}$ & $\begin{array}{l}\text { The PWSQ score did not differ significantly } \\
\text { between the } 2 \text { groups before the interven- } \\
\text { tion ( } p>.05) \text {. After the intervention, the } \\
\text { mean subscale scores were lower in the IG } \\
\text { than in the CG and made a statistically sig- } \\
\text { nificant post-intervention difference be- } \\
\text { tween the groups }(p=.01) \text {. These scores } \\
\text { suggest the effectiveness of the interven- } \\
\text { tion in reducing pregnancy-specific stress. }\end{array}$ & $\begin{array}{l}\text { Pregnancy Wor- } \\
\text { ries and Stress } \\
\text { Questionnaire } \\
\text { (PWSQ) }\end{array}$ & $\begin{array}{l}\text { Preg- } \\
\text { nancy } \\
\text { worries } \\
\text { and } \\
\text { stress }\end{array}$ \\
\hline (52) & $\begin{array}{l}\text { Mary } \\
(2017)\end{array}$ & $\begin{array}{l}\text { India } \\
\text { Date of data } \\
\text { collection } \\
\text { could not be } \\
\text { stated } \\
\text { pre- test, post- } \\
\text { test quantita- } \\
\text { tive research } \\
\text { design } \\
\text { weak }\end{array}$ & $\begin{array}{l}N=50 \\
\text { Age: } \\
64 \% \text { of partici- } \\
\text { pants in CG } \\
\text { and IG were } \\
\text { between } 24-29 \\
\text { years } \\
\text { Primiparous }\end{array}$ & $\begin{array}{l}\text { IG: performed } \\
\text { selected mind } \\
\text { body interven- } \\
\text { tions (Active vis- } \\
\text { ualisation with } \\
\text { Birth Affirma- } \\
\text { tions, yogic } \\
\text { breathing and } \\
\text { relaxation) for } 4 \\
\text { weeks } \\
\text { CG: routine } \\
\text { standard } \\
\text { hospital care }\end{array}$ & $\begin{array}{l}\text { Statistical findings proved that there was a } \\
\text { significant difference in anxiety level } \\
\text { among antenatal women who were sub- } \\
\text { jected to mind body intervention than those } \\
\text { who do not. }\end{array}$ & W-DEQ & FOC \\
\hline
\end{tabular}




\begin{tabular}{|c|c|c|c|c|c|c|c|}
\hline (53) & $\begin{array}{l}\text { Legrand } \\
(2017)\end{array}$ & $\begin{array}{l}\text { France } \\
\text { Date of data } \\
\text { collection } \\
\text { could not be } \\
\text { stated } \\
\text { single-subject } \\
\text { A (baseline)- } \\
\text { B (hypnother- } \\
\text { apy treatment) } \\
-A^{\prime} \text { (return-to- } \\
\text { baseline) re- } \\
\text { search design } \\
\text { weak }\end{array}$ & $\begin{array}{l}\text { N=1 } \\
\text { Age: } 23 \text { years } \\
\text { Primiparous }\end{array}$ & $\begin{array}{l}\text { Hypnotherapy } \\
\text { treatment }\end{array}$ & $\begin{array}{l}\text { A statistically significant declining trend in } \\
\text { anxiety scores was observed during the } \\
\text { hypnosis phase, and anxiety re-increased } \\
\text { in the return-to-baseline phase }(p<.05) \text {. }\end{array}$ & $\begin{array}{l}\text { State Anxiety In- } \\
\text { ventory (SAI) }\end{array}$ & $\begin{array}{l}\text { State } \\
\text { anxiety } \\
\text { during } \\
\text { preg- } \\
\text { nancy }\end{array}$ \\
\hline (54) & $\begin{array}{l}\text { Waisblat } \\
\text { (2017) }\end{array}$ & $\begin{array}{l}\text { France } \\
\text { Date of data } \\
\text { collection } \\
\text { could not be } \\
\text { stated } \\
\text { longitudinal re- } \\
\text { peated } \\
\text { measures } \\
\text { quasi-experi- } \\
\text { mental design } \\
\\
\text { moderate }\end{array}$ & $\begin{array}{l}N=155 \\
\text { Age: } \\
\text { Group S: } 44.3 \\
(13.3) \\
\text { Group H: } 46.3 \\
(7.1) \\
\text { Could not } \\
\text { been stated if } \\
\text { primi-and/or } \\
\text { multiparous }\end{array}$ & $\begin{array}{l}\text { Group S: stand- } \\
\text { ard hypnotic } \\
\text { communication } \\
\text { Group H: hyp- } \\
\text { notic communi- } \\
\text { cation }\end{array}$ & $\begin{array}{l}\text { The mean fear ratings in the Group } \mathrm{H} \text { par- } \\
\text { ticipants was significantly lower than that of } \\
\text { the Group S participants }(p=.001) \text {. }\end{array}$ & $\begin{array}{l}\text { Rating fear of } \\
\text { the epidural } \\
\text { puncture using } \\
\text { the numerical } \\
\text { rating scale } \\
\text { (NRS) with } 0= \\
\text { No pain (fear) } \\
\text { and } 10=\text { Worst } \\
\text { imaginable pain } \\
\text { (fear). }\end{array}$ & $\begin{array}{l}\text { Fear of } \\
\text { women } \\
\text { undergo- } \\
\text { ing labor }\end{array}$ \\
\hline (55) & $\begin{array}{l}\text { Toosi } \\
(2017)(\text { Too } \\
\text { si et al., } \\
2017)(\text { Toos } \\
\text { i et al. } \\
\text { 2017)(Toos } \\
\text { i et al., } \\
\text { 2017)(Toos }\end{array}$ & $\begin{array}{l}\text { Iran } \\
\text { Date of data } \\
\text { collection } \\
\text { could not be } \\
\text { stated }\end{array}$ & $\begin{array}{l}N=80 \\
\text { Age: } \\
\text { IG: } 29.0 \pm 2.4 \\
\text { CG: } 28.7 \pm 2.7 \\
\text { Primiparous }\end{array}$ & $\begin{array}{l}\text { IG: Relaxation } \\
\text { Training (Ben- } \\
\text { son's relaxation } \\
\text { technique) } \\
\text { CG: Routine } \\
\text { care }\end{array}$ & $\begin{array}{l}\text { No significant difference between the two } \\
\text { groups regarding the anxiety score before } \\
\text { the intervention ( } p=.903) \text {. A statistically sig- } \\
\text { nificant difference was observed regarding } \\
\text { the anxiety score after the intervention } \\
(p<.001) \text {. The anxiety score had significa- } \\
\text { ntly decreased in the IG } p<.001) \text {, but had } \\
\text { significantly increased in the CG }(p=.033) \text {. }\end{array}$ & $\begin{array}{l}\text { Spielberger's } \\
\text { state-trait anxi- } \\
\text { ety scale }\end{array}$ & $\begin{array}{l}\text { State/ } \\
\text { Trait } \\
\text { anxiety } \\
\text { during } \\
\text { preg- } \\
\text { nancy }\end{array}$ \\
\hline
\end{tabular}




\begin{tabular}{|c|c|c|c|c|c|c|c|}
\hline & $\begin{array}{l}\text { i et al., } \\
\text { 2017)(Toos } \\
\text { i et al. } \\
\text { 2017)(Toos } \\
\text { i et al., } \\
\text { 2017)(Toos } \\
\text { i et al., } \\
\text { 2017)(Toos } \\
\text { i et al., } \\
\text { 2017)(Toos } \\
\text { i et al. } \\
2017 \text { ) }\end{array}$ & $\begin{array}{l}\text { semi-experi- } \\
\text { mental clinical } \\
\text { trial } \\
\text { moderate }\end{array}$ & & & $\begin{array}{l}\text { Thus, relaxation training was effective in } \\
\text { reduction of anxiety score after the inter- } \\
\text { vention. }\end{array}$ & & \\
\hline (56) & $\begin{array}{l}\text { Sanaati } \\
(2017)\end{array}$ & $\begin{array}{l}\text { Iran } \\
2015 \\
\text { RCT } \\
\text { strong }\end{array}$ & $\begin{array}{l}\text { N=189 } \\
\text { Age: } \\
\text { IG1: } 28.2(5.1) \\
\text { IG2: } 27.5(4.9) \\
\text { CG: } 27.7(4.9) \\
\text { Primi- and } \\
\text { multiparous }\end{array}$ & $\begin{array}{l}\text { Lifestyle based } \\
\text { education: in- } \\
\text { cluded issues } \\
\text { related to sleep, } \\
\text { hygiene, nutri- } \\
\text { tion, physical } \\
\text { activity and ex- } \\
\text { ercise, self-con- } \\
\text { cept and sexual- } \\
\text { ity } \\
\text { IG 1: both } \\
\text { women and their } \\
\text { husbands re- } \\
\text { ceived the life- } \\
\text { style-based edu- } \\
\text { cation. } \\
\text { IG2: only } \\
\text { women received } \\
\text { the lifestyle- } \\
\text { based educa- } \\
\text { tion. } \\
\text { CG: Routine } \\
\text { care }\end{array}$ & $\begin{array}{l}\text { No significant difference on state or trait } \\
\text { anxiety was observed between the groups } \\
\text { before the intervention }(p=.257 ; p=.137) \\
\text { The mean score of state anxiety } 8 \text { weeks } \\
\text { after intervention showed a statistically sig- } \\
\text { nificant difference among the groups } \\
(p<.001) \text {. The mean state anxiety scores in } \\
\text { the IG1 and IG } 2 \text { were significantly reduced } \\
\text { compared to the CG. The mean state anx- } \\
\text { iety score was also significantly reduced in } \\
\text { the IG1 compared to the IG2. } \\
\text { The mean post-intervention score of trait } \\
\text { anxiety showed a statistically significant } \\
\text { difference among the groups ( } p<.001) \text {. } \\
\text { Compared to the CG, the mean trait anxi- } \\
\text { ety score was significantly reduced in the } \\
\text { IG1 and IG2; however, no significant differ- } \\
\text { ence was observed between the two inter- } \\
\text { vention groups. }\end{array}$ & $\begin{array}{l}\text { Spielberger } \\
\text { State-Trait Anxi- } \\
\text { ety Inventory } \\
\text { (STAI) }\end{array}$ & $\begin{array}{l}\text { State/ } \\
\text { Trait Anxi- } \\
\text { ety during } \\
\text { preg- } \\
\text { nancy }\end{array}$ \\
\hline
\end{tabular}




\begin{tabular}{|c|c|c|c|c|c|c|c|}
\hline (57) & $\begin{array}{l}\text { Kordi } \\
(2017)\end{array}$ & $\begin{array}{l}\text { Iran } \\
2015-2016 \\
\text { RCT } \\
\text { strong }\end{array}$ & $\begin{array}{l}N=122 \\
\text { Age: } \\
\text { IG: } 23.2 \pm 3.6 \\
\text { CG: } 24.2 \pm 4.4 \\
\text { Primiparous }\end{array}$ & $\begin{array}{l}\text { IG: psycho- } \\
\text { educational } \\
\text { program for } \\
\text { three weeks } \\
\text { CG: Routine } \\
\text { prenatal care }\end{array}$ & $\begin{array}{l}\text { No significant differences between the } \\
\text { groups with respect to the mean pre- } \\
\text { intervention FOC scores A significant } \\
\text { difference was observed between the IG } \\
\text { and CG in terms of the mean post- } \\
\text { intervention FOC scores }(p=.007) \text {. The } \\
\text { FOC score significantly diminished in the } \\
\text { intervention group in the post-intervention } \\
\text { phase }(p=.001) \text {. }\end{array}$ & W-DEQ & FOC \\
\hline (58) & $\begin{array}{l}\text { Beattie } \\
(2017)\end{array}$ & $\begin{array}{l}\text { Australia } \\
2014 \\
\text { Pilot rando- } \\
\text { mized trial } \\
\text { moderate }\end{array}$ & $\begin{array}{l}N=48 \\
\text { Age: } \\
\text { IG: } 28.9(5.7) \\
\text { CG: } 28.5(6.4) \\
\text { Primi- and } \\
\text { Multiparous }\end{array}$ & $\begin{array}{l}\text { IG: mindfulness- } \\
\text { based support } \\
\text { program (MiPP) } \\
\text { CG: pregnancy } \\
\text { support program } \\
\text { (PSP) }\end{array}$ & $\begin{array}{l}\text { No statistically significant differences be- } \\
\text { tween the IG and the CG were shown on } \\
\text { perceived stress across the three time pe- } \\
\text { riods }(p=.82) \text {. }\end{array}$ & $\begin{array}{l}\text { Perceived } \\
\text { Stress Scale } \\
\text { (PSS-10) (PSS) }\end{array}$ & $\begin{array}{l}\text { Perceived } \\
\text { stress } \\
\text { during } \\
\text { preg- } \\
\text { nancy }\end{array}$ \\
\hline (59) & $\begin{array}{l}\text { Haapio } \\
\text { (2017) }\end{array}$ & $\begin{array}{l}\text { Finland } \\
\text { Date of data } \\
\text { collection has } \\
\text { not been } \\
\text { stated } \\
\text { RCT } \\
\text { weak }\end{array}$ & 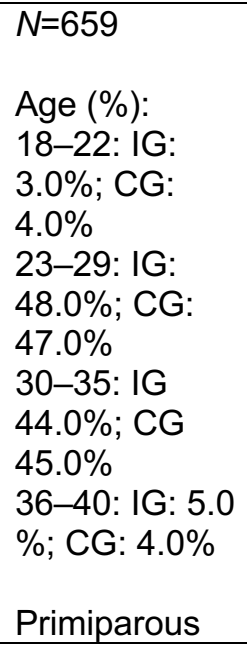 & $\begin{array}{l}\text { IG: extended } \\
\text { childbirth educa- } \\
\text { tion (defined as } \\
\text { a midwife-led in- } \\
\text { tervention with } \\
\text { low medicaliza- } \\
\text { tion) } \\
\text { CG: regular } \\
\text { childbirth educa- } \\
\text { tion }\end{array}$ & $\begin{array}{l}\text { The mothers in the IG had less childbirth- } \\
\text { related fear than those in the CG [odds ra- } \\
\text { tio (OR) } 0.58,95 \% \text { confidence level }(C L) \\
0.38-0.88] \text {. }\end{array}$ & $\begin{array}{l}\text { 'Feelings of } \\
\text { Fear and } \\
\text { Security Associ- } \\
\text { ated with Preg- } \\
\text { nancy and } \\
\text { Childbirth' } \\
\text { Questionnaire }\end{array}$ & FOC \\
\hline $\begin{array}{l}(60) \\
\end{array}$ & $\begin{array}{l}\text { Parsa } \\
(2016)\end{array}$ & $\begin{array}{l}\text { Iran } \\
2015 \\
\text { Quasi experi- } \\
\text { mental study }\end{array}$ & $\begin{array}{l}N=110 \\
\text { Age (IG/CG): } \\
\text { 18-22: } \\
16.4 \% / 5.5 \%\end{array}$ & $\begin{array}{l}\text { IG: counseling } \\
\text { sessions based } \\
\text { on the GATHER } \\
\text { approach }\end{array}$ & $\begin{array}{l}\text { Trait anxiety levels of pregnant women sig- } \\
\text { nificantly changed (were lowered) as a re- } \\
\text { sult of intervention }(p<.001) \text {. However, no } \\
\text { significant difference was found in trait anx- } \\
\text { iety levels of pregnant women in the CG } \\
\text { before and after the intervention. }\end{array}$ & $\begin{array}{l}\text { Spielberger's } \\
\text { State-Trait Anxi- } \\
\text { ety Inventory }\end{array}$ & $\begin{array}{l}\text { State/Trai } \\
\text { t Anxiety } \\
\text { during } \\
\text { preg- } \\
\text { nancy }\end{array}$ \\
\hline
\end{tabular}




\begin{tabular}{|c|c|c|c|c|c|c|c|}
\hline & & strong & $\begin{array}{l}\text { 23-27: } \\
\text { 47.3\%/49.1\% } \\
28-32: \\
29.1 \% / 36.4 \% \\
33-37: 7.3 \% / \\
9.1 \% \\
\\
\text { Primiparous }\end{array}$ & $\begin{array}{l}\text { CG: not descri- } \\
\text { bed }\end{array}$ & $\begin{array}{l}\text { State anxiety levels of pregnant women } \\
\text { significantly changed (were lowered) as a } \\
\text { result of intervention }(p<.001) \text {. However, } \\
\text { no significant difference was found in state } \\
\text { anxiety levels of pregnant women in the } \\
\text { CG before and after the intervention. }\end{array}$ & & \\
\hline (61) & $\begin{array}{l}\text { Aslami } \\
(2016)\end{array}$ & $\begin{array}{l}\text { Iran } \\
2015 \\
\text { RCT } \\
\text { moderate }\end{array}$ & $\begin{array}{l}N=75 \\
\text { Age: } \\
\text { IG 1: } 29.4 \pm 3.8 \\
\text { IG 2: } 27 \pm 3.2 \\
\text { CG: } 28.6 \pm 4.3 \\
\text { Could not } \\
\text { been stated if } \\
\text { primi-or/and } \\
\text { multiparous } \\
\text { women }\end{array}$ & $\begin{array}{l}\text { IG1: treatment } \\
\text { of mindfulness } \\
\text { based on Is- } \\
\text { lamic spiritual } \\
\text { schemes } \\
\text { IG2: cognitive } \\
\text { behavioral ther- } \\
\text { apy group } \\
\text { CG: no course }\end{array}$ & $\begin{array}{l}\text { The significant levels of all tests reveal that } \\
\text { between the anxiety of pregnant women in } \\
\text { the IGs and CG, at least in one of the de- } \\
\text { pendent variables in the } p<.001 \text { level, there } \\
\text { was a significant difference. This finding } \\
\text { shows that in the aforesaid related varia- } \\
\text { bles statistically significant differences are } \\
\text { seen between IG } 1 \text { and IG } 2 \text { and CG. These } \\
\text { findings revealed that both IG } 1 \text { and IG } 2 \text { in } \\
\text { comparison to the CG led to a decrease in } \\
\text { anxiety in pregnant women. The difference } \\
\text { between the average IG1 and IG } 2 \text { in anxi- } \\
\text { ety was significant in the level of .001. } \\
\text { Therefore, the mindfulness treatment } \\
\text { method in comparison with group cognitive } \\
\text { behavioral therapy was more effective on } \\
\text { the reduction of anxiety of pregnant } \\
\text { women. }\end{array}$ & $\begin{array}{l}\text { Beck anxiety- } \\
\text { depression } \\
\text { questionnaire }\end{array}$ & $\begin{array}{l}\text { Anxiety } \\
\text { during } \\
\text { preg- } \\
\text { nancy }\end{array}$ \\
\hline (62) & $\begin{array}{l}\text { Khojasteh } \\
(2016)\end{array}$ & $\begin{array}{l}\text { Iran } \\
2016 \\
\text { RCT } \\
\text { moderate }\end{array}$ & $\begin{array}{l}N=75 \\
\text { Age: } \\
\text { IG1: } 22.76 \pm \\
3.85 \\
\text { IG2: } 23.76 \pm \\
3.74 \\
\text { CG: } 23.92 \pm \\
4.41 \\
\text { Primiparous }\end{array}$ & $\begin{array}{l}\text { IG1: Massage } \\
\text { IG2: Guided Im- } \\
\text { agery } \\
\text { CG: Routine } \\
\text { Care }\end{array}$ & $\begin{array}{l}\text { No significant difference before interven- } \\
\text { tion between groups }(p=063) \text {. The mean } \\
\text { score of anxiety in all three groups had sta- } \\
\text { tistically significant differences after the in- } \\
\text { tervention }(p<.001) \text {. The post-hoc test } \\
\text { showed that the IG1 ( } p .=.000) \text { and IG } \\
(p=.000) \text { had significant lower anxiety } \\
\text { scores compared to the CG, while no sig- } \\
\text { nificant differences were found between } \\
\text { IG1 and IG2 }(p=.928) \text {. }\end{array}$ & $\begin{array}{l}\text { Pregnancy-re- } \\
\text { lated Anxiety } \\
\text { Questionnaire - } \\
\text { revised }\end{array}$ & $\begin{array}{l}\text { Preg- } \\
\text { nancy re- } \\
\text { lated } \\
\text { anxiety }\end{array}$ \\
\hline
\end{tabular}




\begin{tabular}{|c|c|c|c|c|c|c|c|}
\hline (63) & $\begin{array}{l}\text { Sheikh-Az- } \\
\text { adi (2016) }\end{array}$ & $\begin{array}{l}\text { Iran } \\
\text { Date of data } \\
\text { collection } \\
\text { could not be } \\
\text { stated } \\
\text { RCT } \\
\text { moderate }\end{array}$ & $\begin{array}{l}N=60 \\
\text { Age: } \\
\text { IG: } 24(4.388) \\
\text { CG: } 25(4.387) \\
\text { Primiparous }\end{array}$ & $\begin{array}{l}\text { IG: Routine } \\
\text { pregnancy care } \\
\text { + group discus- } \\
\text { sion courses } \\
\text { CG: Routine } \\
\text { pregnancy care }\end{array}$ & $\begin{array}{l}\text { Mean anxiety score before the intervention } \\
\text { was not significantly different between the } \\
\text { IG and CG }(p=.674) \text {. The results showed, } \\
\text { that the mean anxiety score of maternal } \\
\text { state anxiety was significantly different be- } \\
\text { tween the two groups after the intervention } \\
(p=.001) \text {. }\end{array}$ & $\begin{array}{l}\text { Spielberger } \\
\text { Anxiety Inven- } \\
\text { tory }\end{array}$ & $\begin{array}{l}\text { State } \\
\text { anxiety } \\
\text { during } \\
\text { preg- } \\
\text { nancy }\end{array}$ \\
\hline (64) & $\begin{array}{l}\text { Salehi } \\
\text { (2016) }\end{array}$ & $\begin{array}{l}\text { Iran } \\
2015 \\
\text { quasi experi- } \\
\text { mental trial } \\
\text { strong }\end{array}$ & $\begin{array}{l}N=91 \\
\text { Age: } \\
26.04 \pm 4.68 \\
\text { Primiparous }\end{array}$ & $\begin{array}{l}\text { IG1: group cog- } \\
\text { nitive behavioral } \\
\text { therapy (GCBT) } \\
\text { IG2: interactive } \\
\text { lectures group } \\
\text { (IL) } \\
\text { CG: standard } \\
\text { prenatal care }\end{array}$ & $\begin{array}{l}\text { There was a significant difference in the } \\
\text { level of state and trait anxiety in both the } \\
\text { IG1 and IG } 2 \text { groups before and after the } \\
\text { intervention }(p<.001) \text {. However, there were } \\
\text { no differences in state anxiety ( } p=.330) \text { or } \\
\text { trait anxiety ( }(p=.147) \text { in the CG between } \\
\text { baseline and } 4 \text { weeks later. } \\
\text { The results showed significant differences } \\
\text { between the } 3 \text { groups in state anxiety } \\
(p=.011) \text { and trait anxiety }(p=.016) \text {. No sig- } \\
\text { nificant difference was found between IG } 1 \\
\text { and IG } 2 \text { for state anxiety }(p=.079) \text { or trait } \\
\text { anxiety } p=.069) \text {. }\end{array}$ & $\begin{array}{l}\text { Spielberger's } \\
\text { State-Trait Anxi- } \\
\text { ety Inventory }\end{array}$ & $\begin{array}{l}\text { State/ } \\
\text { Trait Anxi- } \\
\text { ety during } \\
\text { preg- } \\
\text { nancy }\end{array}$ \\
\hline (65) & $\begin{array}{l}\text { Beevi } \\
(2016)\end{array}$ & $\begin{array}{l}\text { Malaysia } \\
\text { Date of data } \\
\text { collection } \\
\text { could not be } \\
\text { stated } \\
\text { pre-test/post- } \\
\text { test quasi- ex- } \\
\text { perimental de- } \\
\text { sign } \\
\text { moderate }\end{array}$ & $\begin{array}{l}N=56 \\
\text { Age: } \\
\text { IG: } M=28.23 \\
\mathrm{SD}=3.12 \\
\mathrm{CG}:(\mathrm{M}= \\
29.28 \mathrm{SD}= \\
2.65) \\
\text { Primi- and } \\
\text { Multiparous }\end{array}$ & $\begin{array}{l}\text { IG: Hypnosis in- } \\
\text { tervention } \\
\text { CG: Traditional } \\
\text { antenatal care }\end{array}$ & $\begin{array}{l}\text { Homogeneity of variance }(p>.05) \text { as well } \\
\text { as homogeneity of covariance given } \\
(p=.314) \text {. There was a statistically signifi- } \\
\text { cant interaction between the group and } \\
\text { time for anxiety symptoms, } \\
F(3,126)=7.933, p<.037 \text {, partial } \eta^{2}=.16 \text {. } \\
\text { Results for the simple main effect for group } \\
\text { indicated that there was a statistically sig- } \\
\text { nificant difference in anxiety symptoms at } \\
\text { time point } 3, F(1,44)=10.764, p=.002 \text {, par- } \\
\text { tial } \eta^{2}=.20 \text {, but not at baseline, time point } \\
1 \text { and time point } 2 \text {. There was a statistically } \\
\text { significant effect of time on anxiety symp- } \\
\text { toms for the IG, } F(2.138,58.457)=12.352 \text {, } \\
p=.0005 \text {, partial } \eta^{2}=.38 \text { and the effect of }\end{array}$ & $\begin{array}{l}\text { Depression Anx- } \\
\text { iety Stress } \\
\text { Scale-21 } \\
\text { (DASS-21) }\end{array}$ & $\begin{array}{l}\text { Anxiety } \\
\text { during } \\
\text { preg- } \\
\text { nancy }\end{array}$ \\
\hline
\end{tabular}




\begin{tabular}{|c|c|c|c|c|c|c|c|}
\hline & & & & & $\begin{array}{l}\text { time on anxiety symptoms for the } C G \text { was } \\
\text { not significant, } F(3,66)=0.756, p=.523 \text {, } \\
\text { partial } \eta^{2}=.03 \text {. Following the significant ef- } \\
\text { fect of time for the IG, a pairwise compari- } \\
\text { son was performed and results indicated } \\
\text { that anxiety symptoms were statistically } \\
\text { significantly reduced between time point } 1 \\
\text { and baseline }(M=2.48, S E=0.80, p=.035) \\
\text { between time point } 2 \text { and baseline } \\
(M=3.91, S E=1.18, p=020), \text { between time } \\
\text { point } 3 \text { and baseline }(M=6.10, S E=1.27 \text {, } \\
p=.001) \text {, between time point } 3 \text { and time } \\
\text { point } 1(M=3.62, S E=1.13, p=.026) \text {, but not } \\
\text { statistically significant between time point } 1 \\
\text { and time point } 2 \quad(M=1.43, \quad S E=0.89 \text {, } \\
p=.734) \text { and between time point } 2 \text { and time } \\
\text { point } 3(M=2.19, S E=0.82, p=.085)\end{array}$ & & \\
\hline (66) & $\begin{array}{l}\text { Fontein- } \\
\text { Kuipers } \\
(2016)\end{array}$ & $\begin{array}{l}\text { Netherlands } \\
2013-2015 \\
\text { RCT } \\
\text { strong }\end{array}$ & $\begin{array}{l}N=433 \\
\text { Age: } \\
\text { IG: } 30.11 \\
( \pm 4.09) \\
\text { CG: } 29.98 \\
( \pm 3.71) \\
\\
\text { Primi- and } \\
\text { multiparous }\end{array}$ & $\begin{array}{l}\text { IG: Wazzup } \\
\text { Mama?! focused } \\
1 . \text { on the signs } \\
\text { and symptoms } \\
\text { of maternal dis- } \\
\text { tress and identi- } \\
\text { fication of the } \\
\text { origin of the } \\
\text { state of mood } 2 \text {. } \\
\text { identifying } \\
\text { stressors } 3 \text {. } \\
\text { measurement of } \\
\text { maternal dis- } \\
\text { tress. } \\
\text { CG: antenatal } \\
\text { care as usual }\end{array}$ & $\begin{array}{l}\text { In the CG, the mean STAl scores signifi- } \\
\text { cantly increased from baseline (T1) to } \\
\text { post-intervention (T2) }(p<.001, \quad p<.001 \text {, } \\
p<.001) \text {. Mean PRAQ scores increased but } \\
\text { did not reach statistical significance } \\
\text { ( } p=0.12) \text {. The proportion of STAI and } \\
\text { PRAQ scores above cut- off level signifi- } \\
\text { cantly increased from baseline (T1) to } \\
\text { post-intervention (T2) ( } p<.001, p=.045 \text {, } \\
p=.03) \text {. } \\
\text { In the IG, the mean STAl and PRAQ } \\
\text { scores were significantly lower at T2 com- } \\
\text { pared to T1 ( } p=.001, p<.001, p<.001) \text {. The } \\
\text { proportion of PRAQ scores above cut-off } \\
\text { level were significantly lower at T2 com- } \\
\text { pared to T1 ( } p=.002, p=.009 \text { ). The STAl } \\
\text { scores above cut-off level decreased, but } \\
\text { this did not reach statistical significance } \\
(p=.4, p=.4) \text {. }\end{array}$ & $\begin{array}{l}\text { State-Trait Anxi- } \\
\text { ety Inventory } \\
\text { (STAI) and } \\
\text { Pregnancy-Re- } \\
\text { lated Anxiety } \\
\text { Questionnaire } \\
\text { (PRAQ) }\end{array}$ & $\begin{array}{l}\text { State/ } \\
\text { Trait Anxi- } \\
\text { ety in } \\
\text { preg- } \\
\text { nancy }\end{array}$ \\
\hline
\end{tabular}




\begin{tabular}{|c|c|c|c|c|c|c|c|}
\hline (67) & $\begin{array}{l}\text { Yazdani- } \\
\text { mehr } \\
(2016)\end{array}$ & $\begin{array}{l}\text { Iran } \\
\text { Date of data } \\
\text { collection has } \\
\text { not been } \\
\text { stated } \\
\text { RCT } \\
\text { strong }\end{array}$ & $\begin{array}{l}N=80 \\
\text { Age: } \\
\text { IG: } 26(5.82) \\
\text { CG: } 26.73 \\
(4.54) \\
\text { Primi-and Mul- } \\
\text { tiparous }\end{array}$ & $\begin{array}{l}\text { IG: Mindfulness- } \\
\text { integrated cog- } \\
\text { nitive behavior } \\
\text { therapy } \\
\text { CG: Routine } \\
\text { prenatal care } \\
\text { services }\end{array}$ & $\begin{array}{l}\text { The differences between the study groups } \\
\text { regarding the pretest mean scores of anxi- } \\
\text { ety were not statistically significant }(p<.05) \text {. } \\
\text { The results showed that at T2 and T3, the } \\
\text { mean scores of anxiety in the IG were sig- } \\
\text { nificantly lower than the CG }(p<.001) \text {. }\end{array}$ & $\begin{array}{l}\text { Beck Anxiety In- } \\
\text { ventory }\end{array}$ & $\begin{array}{l}\text { Anxiety } \\
\text { during } \\
\text { preg- } \\
\text { nancy }\end{array}$ \\
\hline (68) & $\begin{array}{l}\text { Nieminen } \\
\text { (2016) }\end{array}$ & $\begin{array}{l}\text { Sweden } \\
\text { 2012- } 2013 \\
\text { feasibility } \\
\text { study } \\
\text { weak }\end{array}$ & $\begin{array}{l}N=28 \\
\text { Age: } \\
30.5(24-39) \\
\text { Primiparous }\end{array}$ & $\begin{array}{l}\text { IG: Internet-de- } \\
\text { livered therapist- } \\
\text { supported self- } \\
\text { help program } \\
\text { based on cogni- } \\
\text { tive behavioral } \\
\text { therapy (ICBT) }\end{array}$ & $\begin{array}{l}\text { Statistically significant }(p<.0005) \text { decrease } \\
\text { of FOC. The W-DEQ sum score decreased } \\
\text { pre- to post-therapy, with a large effect size } \\
\text { (Cohen's } d=0.95) \text {. }\end{array}$ & W-DEQ & FOC \\
\hline (69) & $\begin{array}{l}\text { Karabulut } \\
(2016)\end{array}$ & $\begin{array}{l}\text { Turkey } \\
\text { date of data } \\
\text { collection has } \\
\text { not been } \\
\text { stated } \\
\text { quasi-experi- } \\
\text { mental \& pro- } \\
\text { spective study } \\
\text { strong }\end{array}$ & $\begin{array}{l}N=192 \\
\text { Age: } \\
\text { IG: } 28.87 \pm \\
\text { 4.54 CG: } \\
25.73 \pm 5.35 \\
\text { Primiparous }\end{array}$ & $\begin{array}{l}\text { IG: Antenatal } \\
\text { educational pro- } \\
\text { gram (health in } \\
\text { pregnancy, birth } \\
\text { and breathing } \\
\text { exercises, } \\
\text { breastfeeding, } \\
\text { baby care, post- } \\
\text { partum period } \\
\text { and family plan- } \\
\text { ning) } \\
\text { CG: routine } \\
\text { pregnancy care } \\
\text { and information }\end{array}$ & $\begin{array}{l}\text { The IG's pre-education and IG's first meas- } \\
\text { urement levels of FOC showed significant } \\
\text { differences }(p<.005) \text {. The IG's post-educa- } \\
\text { tion and CG's second measurement levels } \\
\text { of FOC also showed significant differences } \\
\text { ( } p<.005) \text {. According to this finding, antena- } \\
\text { tal education was effective in reducing the } \\
\text { FOC among primipara. }\end{array}$ & W-DEQ-A & FOC \\
\hline (70) & $\begin{array}{l}\text { Karamoo- } \\
\text { zian }(2015)\end{array}$ & $\begin{array}{l}\text { Iran } \\
\text { Date of data } \\
\text { collection has } \\
\text { not been } \\
\text { stated }\end{array}$ & $\begin{array}{l}N=30 \\
\text { Age is not re- } \\
\text { ported } \\
\text { Primiparous }\end{array}$ & $\begin{array}{l}\text { IG: cognitive-be- } \\
\text { havioral stress } \\
\text { management } \\
\text { (CBSM) }\end{array}$ & $\begin{array}{l}\text { There is a significant difference in the ad- } \\
\text { justed average scores of total anxiety be- } \\
\text { tween the IG and CG. The effect of pretest } \\
\text { was significant with } n^{2} p=0.57, p<.01 \text {, and } \\
\mathrm{f}=34.83 \text {. As a result, it can be said that }\end{array}$ & $\begin{array}{l}\text { Pregnancy- Re- } \\
\text { lated Anxiety } \\
\text { Questionnaire }\end{array}$ & $\begin{array}{l}\text { Preg- } \\
\text { nancy re- } \\
\text { lated } \\
\text { anxiety }\end{array}$ \\
\hline
\end{tabular}




\begin{tabular}{|c|c|c|c|c|c|c|c|}
\hline & & $\begin{array}{l}\text { RCT } \\
\text { moderate }\end{array}$ & & $\begin{array}{l}\text { CG: prenatal } \\
\text { care }\end{array}$ & $\begin{array}{l}\text { CBSM significantly reduced the total anxi- } \\
\text { ety in the IG. }\end{array}$ & & \\
\hline (71) & $\begin{array}{l}\text { Rouhe } \\
\text { (2015a) }\end{array}$ & $\begin{array}{l}\text { Finland } \\
\text { 2007-2009 } \\
\text { RCT } \\
\text { Weak }\end{array}$ & $\begin{array}{l}N=371 \\
\text { Age is not re- } \\
\text { ported } \\
\text { Primiparous }\end{array}$ & $\begin{array}{l}\text { IG: group psy- } \\
\text { cho-education } \\
\text { with relaxation } \\
\text { exercises } \\
\text { CG: conventio- } \\
\text { nal care }\end{array}$ & $\begin{array}{l}\text { There was a significant difference between } \\
\text { the groups in mean W-DEQ-B sum scores } \\
(F=1.1 \text {, df }=199, p=.016 \text { Cohen's } d=0.35 \text {, } \\
\text { small effect size), indicating a more fearful } \\
\text { childbirth experience in the CG. } \\
\text { Childbirth experience was less fearful in } \\
\text { the IG compared to the CG across all } \\
\text { modes of delivery, although none of the dif- } \\
\text { ferences reached significance, potentially } \\
\text { because of small sample sizes. }\end{array}$ & W-DEQ A+B & FOC \\
\hline (72) & İsbir(2015) & $\begin{array}{l}\text { Turkey } \\
2014 \\
\text { RCT } \\
\text { strong }\end{array}$ & $\begin{array}{l}N=72 \\
\text { Age: } \\
\text { IG: } 24.9(5.9) \\
\text { CG: } 25.0(4.7) \\
\text { Primi- and } \\
\text { Multiparous }\end{array}$ & $\begin{array}{l}\text { IG: Supportive } \\
\text { Care during la- } \\
\text { bor by midwives } \\
\text { (physical, emo- } \\
\text { tional, instruc- } \\
\text { tional, informa- } \\
\text { tional, advocacy } \\
\text { support) } \\
\text { CG: routine } \\
\text { hospital care }\end{array}$ & $\begin{array}{l}\text { The IG reported less fear of delivery during } \\
\text { the active and transient phases of labor } \\
\text { than the CG }(p<.05) \text {. }\end{array}$ & $\begin{array}{l}\text { W-DEQ } \\
\text { "Delivery fear } \\
\text { scale" }\end{array}$ & $\begin{array}{l}\text { Fear of } \\
\text { delivery }\end{array}$ \\
\hline
\end{tabular}

Note. $\mathrm{IG}=$ experimental group/intervention group; $\mathrm{CG}=$ control group; $\mathrm{RCT}=$ randomized controlled trial; $\mathrm{FOC}=$ fear of childbirth 


\section{Characteristics of the included studies}

Details of the search results are presented in table 2.72 studies fulfilled the inclusion criteria, with a total of 8288 pregnant women. The 72 studies were the basis of the findings within this review. The studies were conducted across 18 countries with most studies from Iran (32 studies), second most from Turkey (7 studies) and third most from Sweden, Netherlands and UK (4 studies), China, Finland and USA ( 3 each), India, Australia and France (2 each), Germany, Iceland, Malawi, Poland, Japan and Malaysia (1 each). Most studies were RCTs, with 47 RCT study designs. The period of time of data collection ranged from 2007 up until 2020.

29 studies included primi- and multiparous women and 31 studies included primiparous women. For 12 studies parity could not be stated.

\section{Outcome variables}

14 studies focused on „fear of childbirth” as an outcome (Abdollahi et al., 2020; Airo (Toivanen) et al., 2018; Amiri et al., 2019; Andaroon et al., 2017; Boryri et al., 2018; Boz et al., 2020; Firouzan et al., 2020; Haapio et al., 2017; Hildingsson et al., 2019; Irmak Vural \& Aslan, 2019; Kacperczyk-Bartnik et al., 2019; Karabulut et al., 2016; Klabbers et al., 2019; Kordi et al., 2017; Larsson et al., in press; Mary et al., 2017; Munkhondya et al., 2020; Narita et al., 2018; Nieminen et al., 2016; Rahmani et al., 2019; Rondung et al., 2018; Rouhe et al., 2015b; Shahsavan et al., 2020; Swift et al., in press; Uçar \& Golbasi, 2019).

Some studies focused on "state/trait anxiety during pregnancy" (Abbasi et al., 2020; Ekrami et al., 2019; Fontein-Kuipers et al., 2016; Goetz et al., 2020; Hamilton et al., 2020; Parsa et al., 2016; Rajeswari \& SanjeevaReddy, 2020; Salehi et al., 2016; Sanaati et al., 2017; Toosi et al., 2017; J.-Y. Zhang et al., 2019), while others focused only on "state anxiety during pregnancy (Esfandiari et al., 2020; Legrand et al., 2017; Mirtabar et al., 2020; Sheikh-Azadi et al., 2016; Uçar \& Golbasi, 2019). 
Some studies had "pregnancy related anxiety as an outcome" (Aksoy Derya et al., 2021; Bazrafshan et al., 2020; Goetz et al., 2020; Karamoozian \& Askarizadeh, 2015; Khojasteh et al., 2016; Zarenejad et al., 2020) and others focused on "anxiety during pregnancy" (Akbarian et al., 2018; Alipour et al., 2020; Aslami et al., 2016; Beevi et al., 2016; Hajmohamadi et al., 2018; Heller et al., 2020; Mohammadi \& Parandin, 2019; Montazeri et al., 2020; Sobhani et al., 2019; Sridhar et al., 2020; van der Zwan et al., 2019; Yazdanimehr et al., 2016; Zemestani, 2019).

Another outcome was "general anxiety during pregnancy" (Krusche et al., 2018; Loughnan, Sie, et al., 2019; Price et al., 2019; Warriner et al., 2018; Yang et al., 2019).

Few studies focused on specific outcome variables like "mental health of pregnant women - anxiety" (Noorbala et al., 2019), "perinatal mood and anxiety disorders" (Waters et al., 2020), "anxiety of pregnant women undergoing interventional prenatal diagnosis" (Kang, 2020), "labor fear" (Uludağ \& Mete, 2020), "fear of women undergoing labor" (Waisblat et al., 2017), "pain catastrophizing" (Duncan et al., 2017), "pregnancy worries and stress" (Seyed Kaboli et al., 2017), "fear of delivery" (İsbir \& Serçekuş, 2015) and "perceived stress during pregnancy" (Beattie et al., 2017).

\section{Interventions applied to pregnant women}

\section{Online vs. offline}

Interventions were delivered in two forms: Via the internet respectively online or digital (Aksoy Derya et al., 2021; Fontein-Kuipers et al., 2016; Heller et al., 2020; Klabbers et al., 2019; Krusche et al., 2018; Larsson et al., in press; Loughnan, Sie, et al., 2019; Nieminen et al., 2016; Price et al., 2019; Rondung et al., 2018; Shahsavan et al., 2020; Yang et al., 2019) or offline respectively face to face. Online "mindfulness based interventions" seem to be effective online/digital (Goetz et al., 2020; Krusche et al., 2018; Price et al., 2019; Yang et al., 
2019). For the offline „mindfulness-based interventions“ results are inconsistent: Several studies find a positive effect (Sobhani et al., 2019; Warriner et al., 2018; Yazdanimehr et al., 2016; Zarenejad et al., 2020; Zemestani, 2019; J.-Y. Zhang et al., 2019), while Beattie et al. (2017) did not show a positive effect of mindfulness-based interventions on perceived stress and Duncan et al. (2017) did not show a positive result on pain catastrophizing. This result does not seem to be affected by the weak ratings of the studies from Goetz et al. (2020), Sobhani et al. (2019) and Warriner et al. (2018).

There are also mixed results concerning the effectiveness of internet based cognitive behavioral therapy, while Larsson et al. (in press) and Loughnan (2019) did not find a between group effect for internet based cognitive behavioral therapy, Nieminen et al. (2016), Rondung et al. (2018) and Shahsavan et al. (2020) showed significant effects in favour of internet based cognitive behavioral therapy. This result has to be interpreted carefully as the studies from Larsson et al. (in press), Loughnan (2019) and Nieminen et al. (2016) are rated as weak.

Fontein-Kuipers (2016) focused on identifying (potential) stress factors, problems or difficult situations in the past or present that may contribute to the development of maternal distress plus gave personal feedback regarding questionnaire results in a web-based tailored program. In the intervention group, the mean state anxiety and pregnancy anxiety scores were significantly lower at $\mathrm{T} 2$ compared to $\mathrm{T} 1$. The proportion of pregnancy anxiety scores above cut-off level were significantly lower at T2 compared to T1 and the state trait anxiety scores above cut-off level decreased, but this did not reach statistical significance.

\section{Categories of interventions}

Summarized within this review are educational interventions: psychoeducation (Bazrafshan et al., 2020; Boz et al., 2020; Hajmohamadi et al., 2018; Klabbers et al., 2019; Kordi et al., 2017; Uçar \& Golbasi, 2019) and more general education (Abbasi et al., 2020; Aksoy Derya et al., 2021; Haapio et al., 2017; Karabulut et al., 2016; Munkhondya et al., 2020; Noorbala et al., 2019). Bazrafshan et al. (2020), Boz et al. (2020), Hajmohamadi et al. (2018), Kordi et al. (2017) and Uçar and Golbasi (2019) found a positive effect for psychoeducation, while the 
study of Klabbers (2019) did not validate this result. Taking the ratings of Uçar (2019) and Klabbers (2019) as weak ratings into account, the results could be interpreted as positive effects for psychoeducational interventions. Abbasi et al. (2020), Haapio et al.(2017), Karabulut et al. (2016), Munkondhya et al. (2020) and Noorbala et al. (2019) showed a positive effect of general education, but the study of Aksoy Derya (2021) is contrary to this result. The weak rating of the study from Haapio et al.(2017) does not seem to affect this result. One study examined the effect of partly psychoeducational, but mostly physiological education and only found a small effect of education on fear of childbirth (Swift et al., in press), while Rahmani et al. (2019) showed that peer education is effective in decreasing FOC in pregnant women.

With regards to relaxation trainings two studies show a positive effect of relaxation techniques like progressive muscle relaxation and relaxation training (Rajeswari \& SanjeevaReddy, 2020; Toosi et al., 2017).

The included studies show mixed results regarding mindfulness-based interventions and their positive effect on anxiety/fear and stress. While several authors found positive influences (Goetz et al., 2020; Krusche et al., 2018; Price et al., 2019; Sobhani et al., 2019; Warriner et al., 2018; Yang et al., 2019; Zarenejad et al., 2020; Zemestani, 2019; J.-Y. Zhang et al., 2019), two studies did not show positive effects of mindfulness-based interventions on perceived stress (Beattie et al., 2017) or on pain catastrophizing (Duncan et al., 2017). This result does not seem to be affected by the weak ratings of the studies from Goetz (2020), Sobhani (2019) and Warriner (2018).

Four studies included in this review examined the effect of hypnotherapeutic interventions. Beevi et al. (2016) stated that an hypnotherapeutic intervention has a positive effect on reducing anxiety during pregnancy. Legrand et al. (2017) also found a positive effect on decreasing state anxiety and also showed a re-increase in the return-to-baseline phase, but this study has to be interpreted carefully, as only one person was examined and the rating of the study 
was weak. Waisblat et al. (2017) examined the effect of hypnotic communication on fear of women undergoing labor and found that hypnotic communication (communication that focusses on the awareness of the patient towards sensations and images that support relaxation and comfort) was more effective than standard communication. In addition fear of labor was significantly lower in a "philosophy of hypnobirthing" group compared to the control group (received routine care) (Uludağ \& Mete, 2020).

Boryri et al. (2018) and Khojasteh et al. (2016) studied the effect of guided imagery on FOC and pregnancy related anxiety and found a significant decrease of fear of delivery on anxiety though guided imagery.

Narita et al. (2018) studied the effect of a heart rate variability (HRV) biofeedback intervention on fear of childbirth and found that FOC was significantly reduced in women who performed HRV biofeedback. Contrary to this result, van der Zwan et al. (2019), who studied a heart rate variability (HRV)-biofeedback intervention combined with a stress-reducing intervention, did not find significant long-term improvements in the HRV-biofeedback condition. But the results on both of those biofeedback intervention studies have to be interpreted carefully due to weak ratings.

Seven studies examined the effect of counselling on anxieties and fears related to pregnancy and childbirth. Seyed Kaboli et al. (2017) showed an effect of counselling on reducing pregnancy-specific stress. Another study, that studied face to face individual counselling conducted by a midwife was effective in reducing fear of childbirth (Andaroon et al., 2017). Ekrami et al. (2019) examined individual and group counselling. The authors found that the mean state and trait anxiety score of the counselling groups were significantly reduced compared to the control group without counselling. In addition Hildingsson et al. (2019) found that it does not make a difference if the counselling is done by a known or unknown midwife. Counselling based on distraction techniques is did not show a significant difference compared 
to a control group intervention (training about signs and stages of delivery and the appropriate time for a referral to the hospital) (Amiri et al., 2019). Parsa et al. (2016) examined counselling sessions based on the GATHER approach and showed that trait and state anxiety levels were lowered due to the intervention. Esfandiari et al. (2020) showed that group supportive counselling scores of state-anxiety were reduced more remarkably than in the CG with a large effect size. Firouzan (2020) examined the difference between face to face counselling and telephone counselling sessions and found that counselling based on the BELIEF protocol was effective in decreasing childbirth fear.

This systematic review also included studies about different therapy tools. Montazeri et al. (2020) showed a significant and reductional effect of writing therapy sessions on anxiety during pregnancy. An acceptance and commitment therapy (ACT) intervention studied by Waters et al. (2020) showed a positive effect on global distress, but must be interpreted carefully due to weak ratings. Alipour et al.(2020) examined the effect of a communication skills training package combined with a couple based intervention as significantly effective in the reduction of anxiety during pregnancy. A cognitive analytic therapy intervention examined by Hamilton et al. (2020) did not show any difference in trait/state anxiety between the randomized groups, but this result has to be interpreted carefully due to a weak rating. Mirtabar et al. (2020) examined the effect of individual structured psychotherapy on state anxiety in preterm labor and showed a significant improvement in the state-anxiety scores compared with the control group (received inpatient medical care for preterm labor). Aslami et al. (2016) studied the effect of a cognitive behavioral therapy group on anxiety during pregnancy and revealed that the cognitive behavioral therapy group in comparison to the control group (no intervention course) led to a decrease in anxiety in pregnant women. This matches the result of Salehi (2016) which also studied the effect of group cognitive behavioral therapy (GCBT) on state/trait anxiety during pregnancy. There was a significant decrease in the level of state and trait anxiety in the GCBT group before and after the intervention. A study about a cognitive 
behavioral stress management intervention showed that this intervention significantly reduced the total anxiety (Karamoozian \& Askarizadeh, 2015).

Also calming virtual reality environments seem to be effective on reducing anxiety during pregnancy, but this effect was mainly seen by qualitative data of the study (Sridhar et al., 2020). A motivational interviewing (MI) psychotherapy intervention showed a large and significant effect on the reduction of fear of childbirth (Abdollahi et al., 2020). Irmak Vural and Aslan (2019) examined the effect of emotional freedom techniques and breathing awareness, both interventions enabled to reduce the level of worries about childbirth. An internet based problem solving treatment studied by Heller et al. (2020) did not show a significant effect in reducing anxiety during pregnancy. Antenatal class attendance reduced delivery fear significantly in first time mothers, but not in multiparous mothers (Kacperczyk-Bartnik et al., 2019). A mental health training course with and without the partner present studied by Akbarian (2018) showed that after the intervention, the mean anxiety score of the pregnant women group was significantly lower than that of the control group and this score was significantly lower in the couples group than that in the pregnant women group. This result has to be interpreted carefully, due to a weak rating. Another study examined the group intervention Nyytti® (with psychoeducation elements, the lifespan model of motivation, practices to support mentalisation and mind-body connection) and showed a significant decrease of fear of childbirth, but has to be interpreted carefully due to weak ratings (Airo (Toivanen) et al., 2018). İsbir and Serçekus (2015) studied the effect of supportive care during labor by a midwife (physical, emotional, instructional, informational, advocacy support) and found that women supported by the midwifes showed significantly less fear on delivery. A "lifestyle based education" (included issues related to sleep, hygiene, nutrition, physical activity and exercise, self-concept and sexuality) found a significant and positive effect, in the direction of reducing state and trait anxiety during pregnancy (Sanaati et al., 2017). 
Kang et al. (2020) examined the effect of different psychological interventions (like psychological support, education, relaxation training, family support, music listening) on anxiety of pregnant women undergoing interventional prenatal diagnosis. The authors found that postoperative anxiety scores were significantly lower in the psychological intervention than in the control group (Kang, 2020), but the results have to be interpreted carefully due to weak ratings. A mind body intervention on the effect of FOC showed a significantly reducing effect on the level of anxiety and anxiety symptoms among antenatal women who were subjected to mind body intervention than those who were not (Mary et al., 2017), but this effect has to be interpreted carefully due to a weak rating. Another study focused on the effect of group discussion in combination with routine care with a significant decrease of state anxiety during pregnancy (Sheikh-Azadi et al., 2016).

\section{Discussion}

\section{Summary of main findings}

This systematic review found a positive effect of psychoeducation, relaxation techniques, guided imagery, counselling (face to face individual counselling from a nown or unknown midwife; group (supportive) counselling; counselling based on the GATHER approach or BELIEF protocol) and different hypnotherapeutic techniques on different fears and anxieties during pregnancy and childbirth, in the sense that those interventions can reduce fears and anxieties in the time of pregnancy and childbirth. Counselling based on distraction techniques did not show a significant difference to a control condition.

For mindfulness-based interventions, mixed results are found, regarding the positive effect of those interventions. Specially an effect on perceived stress and pain catastrophizing could not be shown.

This systematic review also included studies on different therapeutic schools and therapy tools, showing a significant and reductional effect of writing therapy sessions, cognitive behavioral therapy groups, a cognitive behavioral stress intervention, a communication skills training package combined with a couple-based intervention as well as a behavioral therapy 
group in comparison to the control group (no intervention course) on anxiety during pregnancy. Individual structured psychotherapy showed a significant improvement on state anxiety scores.

An acceptance and commitment therapy (ACT) intervention showed a positive effect on global distress, but must be interpreted carefully due to weak ratings. A cognitive analytic therapy did not show any difference in trait/state anxiety between the randomized groups, but this result has to be interpreted carefully due to a weak rating.

Contrary results were shown regarding biofeedback interventions, while one study found that FOC was significantly reduced through biofeedback, another study did not find significant long-term improvements, but those results have to be interpreted carefully due to weak ratings.

Further, single studies about calming virtual reality environments (result only shown within qualitative data), a motivational interviewing psychotherapy, emotional freedom techniques, breathing awareness, a mental health training course (weak rating), the group intervention Nyytti® (with psychoeducation elements, the lifespan model of motivation, practices to support mentalisation and mind-body connection) (weak rating), supportive care through a midwife (physical, emotional, instructional, informational, advocacy support), "lifestyle based education", different psychological interventions (like psychological support, education, relaxation training, family support, music listening) (weak rating), a mind body intervention (weak rating) and group discussion together with routine care seem to be effective in reducing anxiety during pregnancy and childbirth. While an internet-based problem-solving treatment did not show positive effects on reducing anxiety during pregnancy and antenatal class attendance reduced delivery fear significantly in first time, but not multiparous mothers. 


\section{Comparisons with other studies}

\section{Comparison of reviews based on mindfulness-based interventions}

Compared to earlier systematic reviews within the literature, there are on the one side conflicting on the other side similar results. The systematic review and meta-analysis of Dhillon et al. (2017) also found benefits of mindfulness based interventions in RCT and non-RCT studies on anxiety, while mixed results are shown for perceived stress. The pilot randomized trial of Beattie et al. (2017) in this present review did not find a beneficial effect of mindfulness based interventions on perceived stress.

The study of Hall et al. (2012) was not accessible for this review, as only the abstract exists, but the results seem to show a non-significant trend of mindfulness training towards a decrease in anxiety, this stands in conflict with the results within this present study.

Conflicting results also exist in comparison with the study of Lever and Taylor (2016) who in their between-group analyses did not find any significant effect of mindfulness based interventions on anxiety in comparison to control conditions, this is opposed to the results from RCTs (with moderate to strong ratings) of the present study, finding significant between group differences on those examined variables (Krusche et al., 2018; Warriner et al., 2018; Yang et al., 2019; Zarenejad et al., 2020; Zemestani, 2019; J.-Y. Zhang et al., 2019).

Consistent to the present review, Matvienko-Sikar et al. (2016) found in the majority of reviewed papers significant decreases of anxiety trough mindfulness based interventions.

In the review of Riet et al. (2019) mixed results were found in three studies regarding between-group effects of mindfulness based interventions on anxiety. While two studies found a significant between-group effect in favor of the intervention group, one did not, but showed a significant decrease of anxiety due to mindfulness in the intervention group (Riet et al., 2019). In the present study the between-group effect of mindfulness in moderate to strong RCTs on the outcome anxiety is significant and finds similar results compared to Riet et al. (2019).

In the study of Shi and MacBeth (2017) seven RCTs showed significant reductions on anxiety due to mindfulness based interventions compared with control groups and four of five 
non-controlled studies also showed a significant decrease of anxiety. The RCT results within this present review with anxiety as an outcome seem to match with this result.

\section{Comparison of reviews based on hypnotherapeutic interventions}

Two systematic reviews examined the effect of hypnosis based interventions and found a positive impact of hypnosis-based interventions on childbirth experience (Catsaros \& Wendland, 2020; MoghaddamHosseini et al., 2018; Smith et al., 2019a). This finding fits the positive effect of hypnosis-based interventions found in the present study on anxiety and fear.

\section{Comparison of reviews based on (psycho-) educational interventions}

Akgün (2019) examined in their systematic review and meta-analysis the effect of psychoeducation on fear of childbirth and as a result stated, that fear of childbirth was reduced through psychoeducation. This result also fits the result stated within this present review, as positive effects of psychoeducation for fears are summarized. Only one study did not validate this result, but has to be interpreted carefully, due to weak ratings. The clinical review and meta-analysis of MoghaddamHosseini et al. (2018) found a significant effect of educational interventions on reducing fear of childbirth. The systematic reviews of Striebich et al. (2018) supported this result and Stoll et al. (2018) had also positive effects in reducing different anxiety/fear levels.

\section{Comparison of reviews based on different therapeutic techniques/schools}

Three reviews focussed on psychotherapy interventions (Li et al., 2020; Ponting et al., 2020; Sockol, 2018). Li et al. (2020) examined the effect of interpersonal psychotherapy (IPT) on fears and anxieties and found that interpersonal psychotherapy and peer supported interpersonal psychotherapy reduces fears and anxieties during pregnancy and childbirth. Sockol et al. (2018) found similar effects of IPT on anxiety and fears in perinatal women. Contrary to 
this outcome, the review of Ponting (2020) could not confirm this positive effect of IPT. No study within this review focussed on interpersonal psychotherapy.

Regarding cognitive behavioral therapy (studied was the general CBT, not mindfulness based), the systematic review of Li et al. (2020) found mixed effects. While one study did not find a significant between-group effect (Loughnan, Joubert, et al., 2019), other studies found a significant reduction of fear and anxiety during pregnancy and childbirth (Li et al., 2020).

Striebich et al. (2018) stated, that cognitive therapy sessions are effective in reducing fear of childbirth and van Ravesteyn (2017) found the same effect for anxiety disorders. Within this present study mixed results about internet based cognitive behavioral therapy are found, while Larsson et al. (in press) and Loughnan (2019) did not find a between-group effect for internet based cognitive behavioral therapy, Nieminen et al. (2016), Rondung et al. (2018) and Shahsavan et al. (2020) showed significant effects in favour of internet based cognitive behavioral therapy. This result has to be interpretated carefully as the studies from Larsson et al. (in press), Loughnan (2019) and Nieminen et al. (2016) are rated as weak.

Based on the studies of the review of Li et al. (2020), Striebich et al. (2018) and the present study, mixed results for CBT are shown, but when taking the ratings of these studies into account, CBT seems to be effective in reducing fears and anxieties during pregnancy and childbirth.

\section{Comparison of reviews based on writing therapy}

Within this present systematic review, Montazeri et al. (2020) showed a significant and reductional effect of writing therapy sessions on anxiety during pregnancy, which opposes the result of the meta-analysis from Quian et al. (2020), which did not find a significant reducing effect of expressive writing therapy on anxiety.

\section{Comparison with reviews based on e-health and technology-based interventions}

The systematic review and meta-analysis of Bayrampour et al. (2019) showed a significant reduction of anxiety scores in the e-health compared to a control group. Another systematic 
review and meta-analysis showed mixed results for the effect of online cognitive behavioral therapy (Loughnan, Joubert, et al., 2019). Mixed results about internet based cognitive behavioral therapy are also found within the present systematic review. For e-health interventions and their effect on reducing anxiety and fear regarding pregnancy and childbirth, mixed results are found within the present study and earlier systematic reviews and meta-analyses.

\section{Limitations and Strenghts}

Limitations of the present systematic review are differences in the conceptualisations and operationalisations of prenatal anxiety and anxiety and fear during childbirth. Most of the studies are from Iran, so the results could be biased due to cultural background. Also the present review only included studies written in English and German. Another limitation is, that only one person rated the EPHPP criteria. The settings and duration of interventions differed between the studies and this fact could bias the results.

One strength is, that the present study includes the largest number of studies yet known in systematic reviews addressing similar topics.

\section{Study Implications}

The present review only focused on certain therapeutic schools and psychotherapeutic interventions based on cognitive behavioral therapies are overrepresented, while there is only one psychoanalytic study and no study on systemic therapy. Furthermore, there is a need for manualized therapeutic interventions, with regards to a combination of effective intervention components.

\section{Conclusion}

Within this systematic review, a wide range of psychological interventions are shown to be effective in reducing fears and anxieties during pregnancy and childbirth. These results are partly consistent with earlier systematic reviews and meta-analyses. Further research should 
address other acknowledged psychotherapeutic practices, like psychoanalytic or psychodynamic as well as systemic interventions, as they are underrepresented within this review. Furthermore, there is a need for manualized therapeutic interventions, with regards to a combination of effective intervention components. 


\section{Bibliography}

Abbasi, P., Mohammad-Alizadeh Charandabi, S., \& Mirghafourvand, M. (2020). Comparison of the effect of educational software and booklet on anxiety and pain during labour: A randomised controlled clinical trial. Journal of Obstetrics and Gynaecology, 1-8. https://doi.org/10.1080/01443615.2020.1736017

Abdollahi, S., Faramarzi, M., Delavar, M. A., Chehrazi, M., \& Gholinia, H. (2020). Effect of Psychotherapy on Reduction of Fear of Childbirth and Pregnancy Stress: A Randomized Controlled Trial. Frontiers in Psychology, 11, 787. https://doi.org/10.3389/fpsyg.2020.00787

Adams, S., Eberhard-Gran, M., \& Eskild, A. (2012). Fear of childbirth and duration of labour: A study of 2206 women with intended vaginal delivery: Fear of childbirth and duration of labour. BJOG: An International Journal of Obstetrics \& Gynaecology, 119(10), 1238-1246. https://doi.org/10.1111/j.1471-0528.2012.03433.x

Airo (Toivanen), R., Korja, R., Saisto, T., Rouhe, H., Muotka, J., \& Salmela-Aro, K. (2018). Changes in emotions and personal goals in primiparous pregnant women during group intervention for fear of childbirth. Journal of Reproductive and Infant Psychology, 36(4), 363-380. https://doi.org/10.1080/02646838.2018.1462477

Akbarian, Z., Kohan, S., Nasiri, H., \& Ehsanpour, S. (2018). The Effects of Mental Health Training Program on Stress, Anxiety, and Depression during Pregnancy. Iranian Journal of Nursing and Midwifery Research, 23(2), 93-97.

https://doi.org/10.4103/ijnmr.IJNMR_207_16

Akgün, M., Boz, İ., \& Özer, Z. (2019). The effect of psychoeducation on fear of childbirth and birth type: Systematic review and meta-analysis. Journal of Psychosomatic Obstetrics \& Gynecology, 41(4), 253-265. https://doi.org/10.1080/0167482X.2019.1689950 
Aksoy Derya, Y., Altiparmak, S., Akça, E., Gökbulut, N., \& Yilmaz, A. N. (2021). Pregnancy and birth planning during COVID-19: The effects of tele-education offered to pregnant women on prenatal distress and pregnancy-related anxiety. Midwifery, 92, 102877. https://doi.org/10.1016/j.midw.2020.102877

Alipour, Z., Kazemi, A., Kheirabadi, G., \& Eslami, A.-A. (2020). Marital communication skills training to promote marital satisfaction and psychological health during pregnancy: A couple focused approach. Reproductive Health, 17(1), 23. https://doi.org/10.1186/s12978-020-0877-4

Amiri, P., Mirghafourvand, M., Esmaeilpour, K., Kamalifard, M., \& Ivanbagha, R. (2019). The effect of distraction techniques on pain and stress during labor: A randomized controlled clinical trial. BMC Pregnancy and Childbirth, 19(1), 534. https://doi.org/10.1186/s12884-019-2683-y

Andaroon, N., Kordi, M., Kimiaei, S., \& Esmaeily, H. (2017). The effect of individual counseling program by a midwife on fear of childbirth in primiparous women. Journal of Education and Health Promotion, 6(1), 97. https://doi.org/10.4103/jehp.jehp_172_16 Anton, R., \& David, D. (2015). A randomized clinical trial of a new preventive rational emotive and behavioral therapeutical program of prepartum and postpartum emotional distress. Journal of Evidence-Based Psychotherapies, 15, 3-15.

Areskog, B. (1982). Fear of Childbirth in Pregnant Women. In H.-J. Prill, Stauber, Manfred, \& Pechatschek, Paul Georges (Eds.), Advandes in Psychosomatic Obstetrics and Gynecology (1st ed.). Springer Berlin Heidelberg.

Aslami, E., Alipour, A., Najib, F. S., \& Aghayosefi, A. (2016). A Comparative Study of Mindfulness Efficiency Based on Islamic-Spiritual Schemes and Group Cognitive Behavioral Therapy on Reduction of. 5(2), 9. 
Bayrampour, H., Trieu, J., \& Tharmaratnam, T. (2019). Effectiveness of eHealth Interventions to Reduce Perinatal Anxiety: A Systematic Review and Meta-Analysis. The Journal of Clinical Psychiatry, 80(1), 0-0. https://doi.org/10.4088/JCP.18r12386

Bazrafshan, S., Kheirkhah, M., Inanlou, M., \& Rasouli, M. (2020). Controlling the anxiety in Iranian pregnant women at risk of preterm labor by undergoing the counseling group intervention. Journal of Family Medicine and Primary Care, 9(8), 4016. https://doi.org/10.4103/jfmpc.jfmpc_1227_19

Beattie, J., Hall, H., Biro, M. A., East, C., \& Lau, R. (2017). Effects of mindfulness on maternal stress, depressive symptoms and awareness of present moment experience: A pilot randomised trial. Midwifery, 50, 174-183. https://doi.org/10.1016/j.midw.2017.04.006

Beevi, Z., Low, W. Y., \& Hassan, J. (2016). Impact of Hypnosis Intervention in Alleviating Psychological and Physical Symptoms During Pregnancy. American Journal of Clinical Hypnosis, 58(4), 368-382. https://doi.org/10.1080/00029157.2015.1063476

Bhatia, M. S., \& Jhanjee, A. (2012). Tokophobia: A dread of pregnancy. Industrial Psychiatry Journal, 21(2), 158-159. https://doi.org/10.4103/0972-6748.119649

Boryri, T., Navidian, A., \& Marghzari, N. (2018). Comparison of the Effect of Muscle Relaxation and Guided Imagery on Happiness and Fear of Childbirth in Primiparous Women Admitted to Health Care Centers. International Journal of Women's Health and Reproduction Sciences, 7(4), 490-495. https://doi.org/10.15296/ijwhr.2019.81

Boz, İ., Akgün, M., \& Duman, F. (2020). A feasibility study of a psychoeducation intervention based on Human Caring Theory in nulliparous women with fear of childbirth. Journal of Psychosomatic Obstetrics \& Gynecology, 1-13.

https://doi.org/10.1080/0167482X.2020.1752173

Bright, K. S., Charrois, E. M., Kashif Mughal, M., Wajid, A., McNeil, D., Stuart, S., Hayden, K. A., \& Kingston, D. (2019). Interpersonal psychotherapy for perinatal women: A 
systematic review and meta-analysis protocol. Systematic Reviews, 8, 9.

https://doi.org/10.1186/s13643-019-1158-6

Brixval, C. S., Axelsen, S. F., Andersen, S. K., Due, P., \& Koushede, V. (2014). The effect of antenatal education in small classes on obstetric and psycho-social outcomes: A systematic review and meta-analysis protocol. Systematic Reviews, 3(1), 12. https://doi.org/10.1186/2046-4053-3-12

Catsaros, S., \& Wendland, J. (2020). Hypnosis-based interventions during pregnancy and childbirth and their impact on women's childbirth experience: A systematic review. Midwifery, 84, 102666. https://doi.org/10.1016/j.midw.2020.102666

Dhillon, A., Sparkes, E., \& Duarte, R. V. (2017). Mindfulness-Based Interventions During Pregnancy: A Systematic Review and Meta-Analysis. Mindfulness, 8(6), 1421-1437. https://doi.org/10.1007/s12671-017-0726-x

Duncan, L. G., Cohn, M. A., Chao, M. T., Cook, J. G., Riccobono, J., \& Bardacke, N. (2017). Benefits of preparing for childbirth with mindfulness training: A randomized controlled trial with active comparison. BMC Pregnancy and Childbirth, 17(1), 140. https://doi.org/10.1186/s12884-017-1319-3

Ekrami, F., Mohammad-Alizadeh Charandabi, S., Babapour Kheiroddin, J., \& Mirghafourvand, M. (2019). The Effect of Counselling on Depression and Anxiety of Women with Unplanned Pregnancy: A Randomized Controlled Trial. Community Mental Health Journal, 55(6), 1047-1056. https://doi.org/10.1007/s10597-019-00428-2

Elvander, C., Cnattingius, S., \& Kjerulff, K. H. (2013). Birth Experience in Women with Low, Intermediate or High Levels of Fear: Findings from the First Baby Study. Birth, 40(4), 289-296. https://doi.org/10.1111/birt.12065 
Esfandiari, M., Faramarzi, M., Nasiri-Amiri, F., Parsian, H., Chehrazi, M., Pasha, H., Omidvar, S., \& Gholinia, H. (2020). Effect of supportive counseling on pregnancy-specific stress, general stress, and prenatal health behaviors: A multicenter randomized controlled trial. Patient Education and Counseling, 103(11), 2297-2304.

https://doi.org/10.1016/j.pec.2020.04.024

Firouzan, L., Kharaghani, R., Zenoozian, S., Moloodi, R., \& Jafari, E. (2020). The effect of midwifery led counseling based on Gamble's approach on childbirth fear and self-efficacy in nulligravida women. BMC Pregnancy and Childbirth, 20(1), 522. https://doi.org/10.1186/s12884-020-03230-1

Fontein-Kuipers, Y. J., Ausems, M., de Vries, R., \& Nieuwenhuijze, M. J. (2016). The effect of Wazzup Mama?! An antenatal intervention to prevent or reduce maternal distress in pregnancy. Archives of Women's Mental Health, 19(5), 779-788. https://doi.org/10.1007/s00737-016-0614-8

Goetz, M., Schiele, C., Müller, M., Matthies, L. M., Deutsch, T. M., Spano, C., Graf, J., Zipfel, S., Bauer, A., Brucker, S. Y., \& Wallwiener, S. (2020). Effects of a Brief Electronic Mindfulness-Based Intervention on Relieving Prenatal Depression and Anxiety in Hospitalized High-Risk Pregnant Women: Exploratory Pilot Study. Journal of Medical Internet Research, 22(8), 16. https://doi.org/10.2196/17593

Haapio, S., Kaunonen, M., Arffman, M., \& Åstedt-Kurki, P. (2017). Effects of extended childbirth education by midwives on the childbirth fear of first-time mothers: An RCT. Scandinavian Journal of Caring Sciences, 31(2), 293-301. https://doi.org/10.1111/scs.12346

Haines, H. M., Rubertsson, C., Pallant, J. F., \& Hildingsson, I. (2012). The influence of women's fear, attitudes and beliefs of childbirth on mode and experience of birth. BMC Pregnancy and Childbirth, 12(1), 55. https://doi.org/10.1186/1471-2393-12-55 
Hajmohamadi, N., Ghalichi, F., Bakhtari Aghdam, F., \& Matlabi, H. (2018). The "Cooperative-Supportive”, Intervention for Improving Mental Health Status among Pregnant Women. Journal of Caring Sciences, 7(2), 101-106.

Hall, H., Beattie, J., Lau, R., East, C., \& Biro, M. A. (2015). The effectiveness of mindfulness training on perinatal mental health: A systematic review. Integrative Medicine Research, 4(1), 125.

Hall, W. A., Stoll, K., Hutton, E. K., \& Brown, H. (2012). A prospective study of effects of psychological factors and sleep on obstetric interventions, mode of birth, and neonatal outcomes among low-risk British Columbian women. BMC Pregnancy and Childbirth, 12(1), 78. https://doi.org/10.1186/1471-2393-12-78

Hamilton, J., Saxon, D., Best, E., Glover, V., Walters, S. J., \& Kerr, I. B. (2020). A randomized, controlled pilot study of cognitive analytic therapy for stressed pregnant women with underlying anxiety and depression in a routine health service setting. Clinical Psychology \& Psychotherapy, 1-15. https://doi.org/10.1002/cpp.2520

Harrison, V., Moore, D., \& Lazard, L. (2020). Supporting perinatal anxiety in the digital age; a qualitative exploration of stressors and support strategies. BMC Pregnancy and Childbirth, 20(1), 363. https://doi.org/10.1186/s12884-020-02990-0

Heller, H. M., Hoogendoorn, A. W., Honig, A., Broekman, B. F. P., \& van Straten, A. (2020). The Effectiveness of a Guided Internet-Based Tool for the Treatment of Depression and Anxiety in Pregnancy (MamaKits Online): Randomized Controlled Trial. Journal of Medical Internet Research, 22(3), e15172. https://doi.org/10.2196/15172

Hennelly, S. E., Perman-Howe, P., Foxcroft, D. R., \& Smith, L. A. (2020). The feasibility of 'Mind the Bump': A mindfulness based maternal behaviour change intervention. Complementary Therapies in Clinical Practice, 40, 101178.

https://doi.org/10.1016/j.ctcp.2020.101178 
Hildingsson, I., Rubertsson, C., Karlström, A., \& Haines, H. (2019). A known midwife can make a difference for women with fear of childbirth- birth outcome and women's experiences of intrapartum care. Sexual \& Reproductive Healthcare, 21, 33-38. https://doi.org/10.1016/j.srhc.2019.06.004

Hofberg, K, \& Ward, M. R. (2003). Fear of pregnancy and childbirth. Postgraduate Medical Journal, 79(935), 505-510. https://doi.org/10.1136/pmj.79.935.505

Hofberg, Kristina, \& Brockington, I. (2000). Tokophobia: An unreasoning dread of childbirth: A series of 26 cases. British Journal of Psychiatry, 176(1), 83-85. https://doi.org/10.1192/bjp.176.1.83

Hofberg, Kristina, \& Ward, M. R. (2004). Fear of Childbirth, Tocophobia, and Mental Health in Mothers: The Obstetric-Psychiatric Interface: Clinical Obstetrics and Gynecology, 47(3), 527-534. https://doi.org/10.1097/01.grf.0000132527.62504.ca

Irmak Vural, P., \& Aslan, E. (2019). Emotional freedom techniques and breathing awareness to reduce childbirth fear: A randomized controlled study. Complementary Therapies in Clinical Practice, 35, 224-231. https://doi.org/10.1016/j.ctcp.2019.02.011

İsbir, G. G., \& Serçekuş, P. (2015). The Effects of Intrapartum Supportive Care on Fear of Delivery and Labor Outcomes: A Single-Blind Randomized Controlled Trial. Journal of Nursing Research, 1. https://doi.org/10.1097/jnr.0000000000000129

Jahdi, F., Koohsarian, Z., Rasoulian, M., \& Montazerim, A. (2016). Evaluating the effectiveness of empowerment-based education on empowerment and anxiety in nulliparous women. Acta Medica Mediterranea, 32, 1281-1287.

Junge, C., von Soest, T., Weidner, K., Seidler, A., Eberhard-Gran, M., \& Garthus-Niegel, S. (2018). Labor pain in women with and without severe fear of childbirth: A populationbased, longitudinal study. Birth, 45(4), 469-477. https://doi.org/10.1111/birt.12349 
Kacperczyk-Bartnik, J., Bartnik, P., Symonides, A., Sroka-Ostrowska, N., Dobrowolska-Redo, A., \& Romejko-Wolniewicz, E. (2019). Association between antenatal classes attendance and perceived fear and pain during labour. Taiwanese Journal of Obstetrics and Gynecology, 58(4), 492-496. https://doi.org/10.1016/j.tjog.2019.05.011

Kang, C.-M. (2020). Effects of psychological intervention and relevant influence factors on pregnant women undergoing interventional prenatal diagnosis. J Chin Med Assoc, 4.

Kao, M.-H., Hsu, P.-F., Tien, S.-F., \& Chen, C.-P. (2017). Effects of Support Interventions in Women Hospitalized With Preterm Labor. Clinical Nursing Research, 28, 105477381774432. https://doi.org/10.1177/1054773817744323

Karabulut, Ö., Coşkuner Potur, D., Doğan Merih, Y., Cebeci Mutlu, S., \& Demirci, N. (2016). Does antenatal education reduce fear of childbirth?: Does antenatal education reduce fear of childbirth. International Nursing Review, 63(1), 60-67. https://doi.org/10.1111/inr.12223

Karamoozian, M., \& Askarizadeh, G. (2015). Impact of Prenatal Cognitive-Behavioral Stress Management Intervention on Maternal Anxiety and Depression and Newborns' Apgar Scores. Iranian Journal of Neonatalogy, 6(2), 14-23.

https://doi.org/10.22038/IJN.2015.4485

Khojasteh, F., Rezaee, N., Safarzadeh, A., Sahlabadi, R., \& Shahrakipoor, M. (2016). Comparison of the Effects of Massage Therapy and Guided Imagery on Anxiety of Nulliparous Women during Pregnancy. Der Pharmacia Lettre, 8(19), 1-7.

Klabbers, G. A. (2016). Severe Fear of Childbirth: Its Features, Assesment, Prevalence, Determinants, Consequences and Possible Treatments. Psychological Topics, 25, 107-127. 
Klabbers, G. A., Wijma, K., Paarlberg, K. M., Emons, W. H. M., \& Vingerhoets, A. J. J. M. (2019). Haptotherapy as a new intervention for treating fear of childbirth: A randomized controlled trial. Journal of Psychosomatic Obstetrics \& Gynecology, 40(1), 3847. https://doi.org/10.1080/0167482X.2017.1398230

Kordi, M., bakhshi, mohaddeseh, Masoudi, S., \& Esmaily, H. (2017). The effect of childbirth psychoeducational program on severitey childbirth fear in primigravida women. Evidence Based Care, Online First. https://doi.org/10.22038/ebcj.2017.25676.1575

Krusche, A., Dymond, M., Murphy, S. E., \& Crane, C. (2018). Mindfulness for pregnancy: A randomised controlled study of online mindfulness during pregnancy. Midwifery, 65, 51-57. https://doi.org/10.1016/j.midw.2018.07.005

Larsson, B., Karlström, A., Rubertsson, C., Ternström, E., Ekdahl, J., Segebladh, B., \& Hildingsson, I. (in press). Birth preference in women undergoing treatment for childbirth fear: A randomised controlled trial. Women and Birth, 30(6), 460-467. https://doi.org/10.1016/j.wombi.2017.04.004

Laursen, M., Johansen, C., \& Hedegaard, M. (2009). Fear of childbirth and risk for birth complications in nulliparous women in the Danish National Birth Cohort. BJOG: An International Journal of Obstetrics \& Gynaecology, 116(10), 1350-1355.

https://doi.org/10.1111/j.1471-0528.2009.02250.x

Lee, Y., \& Cho, S. (2019). Technology-Supported Interventions for Pregnant Women: A Systematic Review. CIN: Computers, Informatics, Nursing, 37(10), 501-512. https://doi.org/10.1097/CIN.0000000000000535

Legrand, F., Grévin-Laroche, C., Josse, E., Polidori, G., Quinart, H., \& Taïar, R. (2017). Effects of hypnosis during pregnancy: A psychophysiological study on maternal stress. Medical Hypotheses, 102, 123-127. https://doi.org/10.1016/j.mehy.2017.03.026 
Leigh, B., \& Milgrom, J. (2008). Risk factors for antenatal depression, postnatal depression and parenting stress. BMC Psychiatry, 8(1), 24. https://doi.org/10.1186/1471-244X-824

Lever Taylor, B., Cavanagh, K., \& Strauss, C. (2016). The Effectiveness of MindfulnessBased Interventions in the Perinatal Period: A Systematic Review and Meta-Analysis. PLOS ONE, 11(5). https://doi.org/10.1371/journal.pone.0155720

Li, C., Sun, X., Li, Q., Sun, Q., Wu, B., \& Duan, D. (2020). Role of psychotherapy on antenatal depression, anxiety, and maternal quality of life. Medicine, 99(27). https://doi.org/10.1097/MD.0000000000020947

Loughnan, S. A., Joubert, A. E., Grierson, A., Andrews, G., \& Newby, J. M. (2019). Internetdelivered psychological interventions for clinical anxiety and depression in perinatal women: A systematic review and meta-analysis. Archives of Women's Mental Health, 22(6), 737-750. https://doi.org/10.1007/s00737-019-00961-9

Loughnan, S. A., Sie, A., Hobbs, M. J., Joubert, A. E., Smith, J., Haskelberg, H., Mahoney, A. E. J., Kladnitski, N., Holt, C. J., Milgrom, J., Austin, M.-P., Andrews, G., \& Newby, J. M. (2019). A randomized controlled trial of "MUMentum Pregnancy": Internet-delivered cognitive behavioral therapy program for antenatal anxiety and depression. Journal of Affective Disorders, 243, 381-390. https://doi.org/10.1016/j.jad.2018.09.057

Madhavanprabhakaran, G. K., D’Souza, M. S., \& Nairy, K. S. (2015). Prevalence of pregnancy anxiety and associated factors. International Journal of Africa Nursing Sciences, 3, 1-7. https://doi.org/10.1016/j.ijans.2015.06.002

Mary, A. J. K., Latheef, F., \& Vijayaraghavan, R. (2017). Effectiveness of selected mind body interventions on anxiety related to childbirth and labour outcomes. 16, 7. 
Matvienko-Sikar, K., Lee, L., Murphy, G., \& Murphy, L. (2016). The effects of mindfulness interventions on prenatal well-being: A systematic review. Psychology \& Health, 31(12), 1415-1434. https://doi.org/10.1080/08870446.2016.1220557

Mirtabar, S. M., Faramarzi, M., Khazaei, R., \& Dini, M. (2020). Efficacy of psychotherapy for anxiety reduction in hospital management of women successfully treated for preterm labor: A randomized controlled trial. Women \& Health, 60(10), 1151-1163. https://doi.org/10.1080/03630242.2020.1803464

Misri, S., Abizadeh, J., Sanders, S., \& Swift, E. (2015). Perinatal Generalized Anxiety Disorder: Assessment and Treatment. Journal of Women's Health, 24(9), 762-770. https://doi.org/10.1089/jwh.2014.5150

Moghaddam Hosseini, V., Nazarzadeh, M., \& Jahanfar, S. (2018). Interventions for reducing fear of childbirth: A systematic review and meta-analysis of clinical trials. Women and Birth, 31(4), 254-262. https://doi.org/10.1016/j.wombi.2017.10.007

MoghaddamHosseini, V., Nazarzadeh, M., \& Jahanfar, S. (2018). Interventions for reducing fear of childbirth: A systematic review and meta-analysis of clinical trials. Women and Birth, 31(4), 254-262. https://doi.org/10.1016/j.wombi.2017.10.007

Mohammadi, M. M., \& Parandin, S. (2019). Effect of the combination of Benson's relaxation technique and brief psychoeducational intervention on multidimensional pain and negative psychological symptoms of pregnant women: A randomized controlled trial. Journal of Education and Health Promotion, 8, 7.

Moher, D., Liberati, A., Tetzlaff, J., Altman, D. G., \& The PRISMA Group. (2009). Preferred Reporting Items for Systematic Reviews and Meta-Analyses: The PRISMA Statement. PLoS Medicine, 6(7), e1000097. https://doi.org/10.1371/journal.pmed.1000097 Montazeri, M., Esmaeilpour, K., Mohammad-Alizadeh-Charandabi, S., Golizadeh, S., \& Mirghafourvand, M. (2020). The Effect of Writing Therapy on Anxiety in Pregnant 
Women: A Randomized Controlled Trial. Iranian Journal of Psychiatry and Behavioral Sciences, 14(2). https://doi.org/10.5812/ijpbs.98256

Moudi, Z., Molashahi, B., Ansari, H., \& Imani, M. (2018). The effect of a care program and social support on anxiety level in mothers of late preterm infants in Sistan and Baluchestan, Iran. Women \& Health, 569-578. https://doi.org/10.1080/03630242.2018.1508540

Munkhondya, B. M. J., Munkhondya, T. E., Chirwa, E., \& Wang, H. (2020). Efficacy of companion-integrated childbirth preparation for childbirth fear, self-efficacy, and maternal support in primigravid women in Malawi. BMC Pregnancy and Childbirth, 20(1), 48. https://doi.org/10.1186/s12884-019-2717-5

Najafi, Z., Mohebi, S., Gharlipour, Z., Rajabi, M., \& Sharifirad, G. (2019). The effectiveness of emotional intelligence training on anxiety in primigravid women. Cochrane Central Register of Controlled Trials, 8. https://doi.org/10.1002/central/CN-01956746

Narita, Y., Shinohara, H., \& Kodama, H. (2018). Resting Heart Rate Variability and the Effects of Biofeedback Intervention in Women with Low-Risk Pregnancy and Prenatal Childbirth Fear. Applied Psychophysiology and Biofeedback, 43(2), 113-121. https://doi.org/10.1007/s10484-018-9389-1

Nasiri, S., Akbari, H., Tagharrobi, L., \& Tabatabaee, A. (2018). The effect of progressive muscle relaxation and guided imagery on stress, anxiety, and depression of pregnant women referred to health centers. Journal of Education and Health Promotion, 7. https://doi.org/10.4103/jehp.jehp_158_16

Nettelbladt, P., Fagerström, C.-F., \& Uddenberg, N. (1976). The significance of reported childbirth pain. Journal of Psychosomatic Research, 20(3), 215-221. https://doi.org/10.1016/0022-3999(76)90024-6 
Nieminen, K., Andersson, G., Wijma, B., Ryding, E.-L., \& Wijma, K. (2016). Treatment of nulliparous women with severe fear of childbirth via the Internet: A feasibility study. Journal of Psychosomatic Obstetrics \& Gynecology, 37(2), 37-43. https://doi.org/10.3109/0167482X.2016.1140143

Noorbala, A. A., Afzali, H. M., Abedinia, N., Akhbari, M., Moravveji, S. A., \& Shariat, M. (2019). Investigation of the effectiveness of psychiatric interventions on the mental health of pregnant women in Kashan City - Iran: A clinical trial study. Asian Journal of Psychiatry, 46, 79-86. https://doi.org/10.1016/j.ajp.2019.09.036

O’Connell, Maeve A., Leahy-Warren, P., Kenny, L. C., O’Neill, S. M., \& Khashan, A. S. (2019). The prevalence and risk factors of fear of childbirth among pregnant women: A cross-sectional study in Ireland. Acta Obstetricia et Gynecologica Scandinavica, 98(8), 1014-1023. https://doi.org/10.1111/aogs.13599

O’Connell, Maeve A., Leahy-Warren, P., Khashan, A. S., Kenny, L. C., \& O’Neill, S. M. (2017). Worldwide prevalence of tocophobia in pregnant women: Systematic review and meta-analysis. Acta Obstetricia et Gynecologica Scandinavica, 96(8), 907-920. https://doi.org/10.1111/aogs.13138

O’Connell, Maeve Anne, O’Neill, S. M., Dempsey, E., Khashan, A. S., Leahy-Warren, P., Smyth, R. M., \& Kenny, L. C. (2019). Interventions for fear of childbirth (tocophobia). Cochrane Database of Systematic Reviews, 5.

https://doi.org/10.1002/14651858.CD013321

O’Connor, T. G., Heron, J., Golding, J., Beveridge, M., \& Glover, V. (2002). Maternal antenatal anxiety and children's behavioural/emotional problems at 4 years. British Journal of Psychiatry, 180(06), 502-508. https://doi.org/10.1192/bjp.180.6.502 
Parsa, P., Saeedzadeh, N., Zahra Masoumi, S., \& Roshanaei, G. (2016). The Effectiveness of Counseling in Reducing Anxiety Among Nulliparous Pregnant Women. Journal of Family and Reproductive Health, 10(4), 198-205.

Poggi, L., Goutaudier, N., Séjourné, N., \& Chabrol, H. (2018). When Fear of Childbirth is Pathological: The Fear Continuum. Maternal and Child Health Journal, 22(5), 772778. https://doi.org/10.1007/s10995-018-2447-8

Ponting, C., Mahrer, N. E., Zelcer, H., Dunkel Schetter, C., \& Chavira, D. A. (2020). Psychological interventions for depression and anxiety in pregnant Latina and Black women in the United States: A systematic review. Clinical Psychology \& Psychotherapy, 27(2), 249-265. https://doi.org/10.1002/cpp.2424

Price, C., Kantrowitz-Gordon, I., \& Calhoun, R. (2019). A pilot feasibility study of mindfulness childbirth education for women with a history of sexual trauma. Complementary Therapies in Clinical Practice, 37, 102-108. https://doi.org/10.1016/j.ctcp.2019.09.005

Qian, J., Zhou, X., Sun, X., Wu, M., Sun, S., \& Yu, X. (2020). Effects of expressive writing intervention for women's PTSD, depression, anxiety and stress related to pregnancy: A meta-analysis of randomized controlled trials. Psychiatry Research, 288, 112933. https://doi.org/10.1016/j.psychres.2020.112933

Rahmani, R., Yaghoobi Moghadam, F., Hadizadeh-Talasaz, F., \& Rahmani, M. R. (2019). The Effect of Peer Education on Fear of Childbirth in Pregnant Women: A Randomized Clinical Trial. International Journal of Women's Health and Reproduction Sciences, 8(2), 209-214. https://doi.org/10.15296/ijwhr.2020.33

Räisänen, S., Lehto, S., Nielsen, H., Gissler, M., Kramer, M., \& Heinonen, S. (2014). Fear of childbirth in nulliparous and multiparous women: A population-based analysis of all singleton births in Finland in 1997-2010. BJOG: An International Journal of Obstetrics \& Gynaecology, 121(8), 965-970. https://doi.org/10.1111/1471-0528.12599 
Rajeswari, S., \& SanjeevaReddy, N. (2020). Efficacy of progressive muscle relaxation on pregnancy outcome among anxious indian primi mothers. Iranian Journal of Nursing and Midwifery Research, 25(1), 23. https://doi.org/10.4103/ijnmr.IJNMR_207_18

Reck, C., Zimmer, K., Dubber, S., Zipser, B., Schlehe, B., \& Gawlik, S. (2013). The influence of general anxiety and childbirth-specific anxiety on birth outcome. Archives of Women's Mental Health, 16(5), 363-369. https://doi.org/10.1007/s00737-013-0344-0

Riet, P., Francis, L., \& Rees, A. (2019). Exploring the impacts of mindfulness and yoga upon childbirth outcomes and maternal health: An integrative review. Scandinavian Journal of Caring Sciences, scs.12762. https://doi.org/10.1111/scs.12762

Rondung, E., Ternström, E., Hildingsson, I., Sundin, Ö., Ekdahl, J., Larsson, B., Segeblad, B., Baylis, R., \& Rubertsson, C. (2018). Comparing Internet-Based Cognitive Behavioral Therapy With Standard Care for Women With Fear of Birth: Randomized Controlled Trial. JMIR Mental Health, 5(3).

Rouhe, H., Salmela-Aro, K., Toivanen, R., Tokola, M., Halmesmäki, E., Ryding, E.-L., \& Saisto, T. (2015a). Group psychoeducation with relaxation for severe fear of childbirth improves maternal adjustment and childbirth experience - a randomised controlled trial. Journal of Psychosomatic Obstetrics \& Gynecology, 36(1), 1-9. https://doi.org/10.3109/0167482X.2014.980722

Rouhe, H., Salmela-Aro, K., Toivanen, R., Tokola, M., Halmesmäki, E., Ryding, E.-L., \& Saisto, T. (2015b). Group psychoeducation with relaxation for severe fear of childbirth improves maternal adjustment and childbirth experience - a randomised controlled trial. Journal of Psychosomatic Obstetrics \& Gynecology, 36(1), 1-9. https://doi.org/10.3109/0167482X.2014.980722 
Salehi, F., Pourasghar, M., Khalilian, A., \& Shahhosseini, Z. (2016). Comparison of group cognitive behavioral therapy and interactive lectures in reducing anxiety during pregnancy: A quasi experimental trial. Medicine, 95(43), e5224. https://doi.org/10.1097/MD.0000000000005224

San Lazaro Campillo, I., Meaney, S., McNamara, K., \& O’Donoghue, K. (2017). Psychological and support interventions to reduce levels of stress, anxiety or depression on women's subsequent pregnancy with a history of miscarriage: An empty systematic review. BMJ Open, 7(9). https://doi.org/10.1136/bmjopen-2017-017802

Sanaati, F., Mohammad-Alizadeh Charandabi, S., Farrokh Eslamlo, H., Mirghafourvand, M., \& Alizadeh Sharajabad, F. (2017). The effect of lifestyle-based education to women and their husbands on the anxiety and depression during pregnancy: A randomized controlled trial. The Journal of Maternal-Fetal \& Neonatal Medicine, 30(7), 870-876. https://doi.org/10.1080/14767058.2016.1190821

Seyed Kaboli, K., Mahmoodi, Z., Mehdizadeh Tourzani, Z., Tehranizadeh, M., Kabir, K., \& Dolatian, M. (2017). The Effect of Group Counseling Based on Cognitive-Behavioral Approach on Pregnancy-Specific Stress and Anxiety. Shiraz E-Medical Journal, 18(5). https://doi.org/10.5812/semj.45231

Shahsavan, F., Akbari, N., Gharraee, B., Abolghasemi, J., \& Khedmat, L. (2020). The effect of internet-based guided self-help cognitive-behavioral therapies on Iranian women's psychological symptoms and preferred method of childbirth. Perspectives in Psychiatric Care, 1-10. https://doi.org/10.1111/ppc.12535

Sheikh-Azadi, E., Bakhteh, A., Rezaei, M., \& Ashtareian, H. (2016). The effect of group discussion in primigravidas. Research Journal of Medical Sciences, 10(5), 498-502. 
Shi, Z., \& MacBeth, A. (2017). The Effectiveness of Mindfulness-Based Interventions on Maternal Perinatal Mental Health Outcomes: A Systematic Review. Mindfulness, 8(4), 823-847. https://doi.org/10.1007/s12671-016-0673-y

Slade, P., Balling, K., Sheen, K., \& Houghton, G. (2019). Establishing a valid construct of fear of childbirth: Findings from in-depth interviews with women and midwives. $B M C$ Pregnancy and Childbirth, 19(1), 96. https://doi.org/10.1186/s12884-019-2241-7

Smith, C. A., Shewamene, Z., Galbally, M., Schmied, V., \& Dahlen, H. (2019a). The effect of complementary medicines and therapies on maternal anxiety and depression in pregnancy: A systematic review and meta-analysis. Journal of Affective Disorders, 245, 428-439. https://doi.org/10.1016/j.jad.2018.11.054

Smith, C. A., Shewamene, Z., Galbally, M., Schmied, V., \& Dahlen, H. (2019b). The effect of complementary medicines and therapies on maternal anxiety and depression in pregnancy: A systematic review and meta-analysis. Journal of Affective Disorders, 245, 428-439. https://doi.org/10.1016/j.jad.2018.11.054

Sobhani, E., Babakhani, N., \& Alboe, M. R. (2019). The Effectiveness of Mindfulness-Based Stress Reduction on the Depression, Anxiety, Stress, and Pain Perception in Females with Obstructed Labour-Induced Chronic Low Back Pain. Iranian Journal of Psychiatry and Clinical Psychology, 25(3), 266-277. https://doi.org/10.32598/ijpcp.25.3.266

Sockol, L. E. (2018). A systematic review and meta-analysis of interpersonal psychotherapy for perinatal women. Journal of Affective Disorders, 232, 316-328. https://doi.org/10.1016/j.jad.2018.01.018

Söderquist, J., Wijma, B., Thorbert, G., \& Wijma, K. (2009). Risk factors in pregnancy for post-traumatic stress and depression after childbirth. BJOG: An International Journal of Obstetrics \& Gynaecology, 116(5), 672-680. https://doi.org/10.1111/j.14710528.2008.02083.x 
Soltani, F., Eskandari, Z., Khodakarami, B., Parsa, P., \& Roshanaei, G. (2017). The effect of self-efficacy oriented counselling on controlling the fear of natural delivery in primigravida women. Journal of Pharmaceutical Sciences and Research, 9, 1757-1761.

Sridhar, A., Shiliang, Z., Woodson, R., \& Kwan, L. (2020). Non-pharmacological anxiety reduction with immersive virtual reality for first-trimester dilation and curettage: A pilot study. The European Journal of Contraception \& Reproductive Health Care, 25(6), 480-483. https://doi.org/10.1080/13625187.2020.1836146

Stoll, K., Swift, E. M., Fairbrother, N., Nethery, E., \& Janssen, P. (2018). A systematic review of nonpharmacological prenatal interventions for pregnancy-specific anxiety and fear of childbirth. Birth, 45(1), 7-18. https://doi.org/10.1111/birt.12316

Størksen, H. T., Garthus-Niegel, S., Adams, S. S., Vangen, S., \& Eberhard-Gran, M. (2015). Fear of childbirth and elective caesarean section: A population-based study. $B M C$ Pregnancy and Childbirth, 15(1), 221. https://doi.org/10.1186/s12884-015-0655-4

Stratton, E., Lampit, A., Choi, I., Calvo, R. A., Harvey, S. B., \& Glozier, N. (2017). Effectiveness of eHealth interventions for reducing mental health conditions in employees: A systematic review and meta-analysis. PLOS ONE, 12(12), e0189904. https://doi.org/10.1371/journal.pone.0189904

Striebich, S., \& Ayerle, G. M. (2019). Fear of childbirth (FOC): Pregnant women's perceptions towards the impending hospital birth and coping resources - a reconstructive study. Journal of Psychosomatic Obstetrics \& Gynecology, 1-9. https://doi.org/10.1080/0167482X.2019.1657822

Striebich, S., \& Ayerle, G. M. (2020). Große Angst vor der Geburt bei schwangeren Frauen inDeutschland: Erfahrungen und Orientierungen in Bezugauf die Schwangerenbetreuung und die Geburts-vorbereitung - eine rekonstruktive Studie. Vol.7. 
Striebich, S., Mattern, E., \& Ayerle, G. M. (2018). Support for pregnant women identified with fear of childbirth (FOC)/tokophobia - A systematic review of approaches and interventions. Midwifery, 61, 97-115. https://doi.org/10.1016/j.midw.2018.02.013

Sutter-Dallay, A. L., Giaconne-Marcesche, V., Glatigny-Dallay, E., \& Verdoux, H. (2004). Women with anxiety disorders during pregnancy are at increased risk of intense postnatal depressive symptoms: A prospective survey of the MATQUID cohort. European Psychiatry, 19(8), 459-463. https://doi.org/10.1016/j.eurpsy.2004.09.025

Swift, E. M., Zoega, H., Stoll, K., Avery, M., \& Gottfreðsdóttir, H. (in press). Enhanced Antenatal Care: Combining one-to-one and group Antenatal Care models to increase childbirth education and address childbirth fear. Women and Birth. https://doi.org/10.1016/j.wombi.2020.06.008

Toosi, M., Akbarzadeh, M., \& Ghaemi, Z. (2017). The Effect of Relaxation on Mother's Anxiety and Maternal-Fetal Attachment in Primiparous IVF Mothers. Journal of the $\mathrm{Na}$ tional Medical Association, 109(3), 164-171.

https://doi.org/10.1016/j.jnma.2017.03.002

Uçar, T., \& Golbasi, Z. (2019). Effect of an educational program based on cognitive behavioral techniques on fear of childbirth and the birth process. Journal of Psychosomatic Obstetrics \& Gynecology, 40(2), 146-155.

https://doi.org/10.1080/0167482X.2018.1453800

Uludağ, E., \& Mete, S. (2020). The effect of nursing care provided based on the philosophy of hypnobirthing on fear, pain, duration, satisfaction and cost of labor: A single-blind randomized controlled study: The effect of nursing care on the labor process and cost. Health Care for Women International, 1-13. https://doi.org/10.1080/07399332.2020.1835916 
van der Zwan, J., Huizink, A., Lehrer, P., Koot, H., \& de Vente, W. (2019). The Effect of Heart Rate Variability Biofeedback Training on Mental Health of Pregnant and NonPregnant Women: A Randomized Controlled Trial. International Journal of Environmental Research and Public Health, 16(6), 1051.

https://doi.org/10.3390/ijerph16061051

van Ravesteyn, L. M., Lambregtse - van den Berg, M. P., Hoogendijk, W. J. G., \& Kamperman, A. M. (2017). Interventions to treat mental disorders during pregnancy: A systematic review and multiple treatment meta-analysis. PLOS ONE, 12(3), e0173397. https://doi.org/10.1371/journal.pone.0173397

Viswasam, K., Eslick, G. D., \& Starcevic, V. (2019). Prevalence, onset and course of anxiety disorders during pregnancy: A systematic review and meta analysis. Journal of Affective Disorders, 255, 27-40. https://doi.org/10.1016/j.jad.2019.05.016

Waisblat, V., Langholz, B., Bernard, F. J., Arnould, M., Benassi, A., Ginsbourger, F., Guillou, N., Hamelin, K., Houssel, P., Hugot, P., Martel-Jacob, S., Moufouki, M., Musellec, H., Nid Mansour, S., Ogagna, D., Paqueron, X., Zerguine, S., Cavagna, P., Bloc, S., ... Dhonneur, G. (2017). Impact of a Hypnotically-Based Intervention on Pain and Fear in Women Undergoing Labor. International Journal of Clinical and Experimental Hypnosis, 65(1), 64-85. https://doi.org/10.1080/00207144.2017.1246876

Warriner, S., Crane, C., Dymond, M., \& Krusche, A. (2018). An evaluation of mindfulnessbased childbirth and parenting courses for pregnant women and prospective fathers/partners within the UK NHS (MBCP-4-NHS). Midwifery, 64, 1-10. https://doi.org/10.1016/j.midw.2018.05.004

Waters, C. S., Annear, B., Flockhart, G., Jones, I., Simmonds, J. R., Smith, S., Traylor, C., \& Williams, J. F. (2020). Acceptance and Commitment Therapy for perinatal mood and 
anxiety disorders: A feasibility and proof of concept study. British Journal of Clinical Psychology, 59(4), 461-479. https://doi.org/10.1111/bjc.12261

Wijma, K. (2003). Why focus on 'fear of childbirth'? Journal of Psychosomatic Obstetrics \& Gynecology, 24(3), 141-143. https://doi.org/10.3109/01674820309039667

Wijma, Klaas, \& Wijma, B. (2017). A Woman Afraid to Deliver: How to Manage Childbirth Anxiety. In K. M. Paarlberg \& H. B. M. van de Wiel (Eds.), Bio-Psycho-Social Obstetrics and Gynecology (pp. 3-31). Springer International Publishing. https://doi.org/10.1007/978-3-319-40404-2_1

Yang, M., Jia, G., Sun, S., Ye, C., Zhang, R., \& Yu, X. (2019). Effects of an Online Mindfulness Intervention Focusing on Attention Monitoring and Acceptance in Pregnant Women: A Randomized Controlled Trial. Journal of Midwifery \& Women's Health, 11. https://doi.org/doi:10.1111/jmwh.12944

Yazdanimehr, R., Omidi, A., Sadat, Z., \& Akbari, H. (2016). The Effect of Mindfulness-integrated Cognitive Behavior Therapy on Depression and Anxiety among Pregnant Women: A Randomized Clinical Trial. Journal of Caring Sciences, 5(3), 195-204. https://doi.org/10.15171/jcs.2016.021

Zar, M., Wijma, K., \& Wijma, B. (2002). Relations between anxiety disorders and fear of childbirth during late pregnancy. Clinical Psychology \& Psychotherapy, 9(2), 122130. https://doi.org/10.1002/cpp.305

Zarenejad, M., Yazdkhasti, M., Rahimzadeh, M., Mehdizadeh Tourzani, Z., \& EsmaelzadehSaeieh, S. (2020). The effect of mindfulness-based stress reduction on maternal anxiety and self-efficacy: A randomized controlled trial. Brain and Behavior, 10(4). https://doi.org/10.1002/brb3.1561 
Zemestani, M. (2019). Effectiveness of mindfulness-based cognitive therapy for comorbid depression and anxiety in pregnancy: A randomized controlled trial. Arch Womens Ment Health, 23, 8.

Zhang, A., Park, S., Sullivan, J. E., \& Jing, S. (2018). The Effectiveness of Problem-Solving Therapy for Primary Care Patients’ Depressive and/or Anxiety Disorders: A Systematic Review and Meta-Analysis. The Journal of the American Board of Family Medicine, 31(1), 139-150. https://doi.org/10.3122/jabfm.2018.01.170270

Zhang, J.-Y., Cui, Y.-X., Zhou, Y.-Q., \& Li, Y.-L. (2019). Effects of mindfulness-based stress reduction on prenatal stress, anxiety and depression. Psychology, Health \& Medicine, 24(1), 51-58. https://doi.org/10.1080/13548506.2018.1468028 


\section{Declarations}

Ethics approval and consent to participate: Not applicable.

Consent for publication: I declare, that all co-authors have given informed consent to publication of the manuscript.

Funding: We acknowledge that funding was kindly provided by the european regional development fund, grant number: 85037910.

Competing interests: None declared.

Availability of data and materials: The Zotero library and the excel sheet to extract duplicates used in the search strategy are available from the corresponding author on reasonable request.

Authors' contributions: CB conceived the study and screened and selected the studies. GG independently checked the content. All authors helped draft the manuscript. CB and GG read and approved the final manuscript. CB is the lead author.

Acknowledgements: We are sincerely thankful to Julia Huwer, to support us during the course of this paper. 


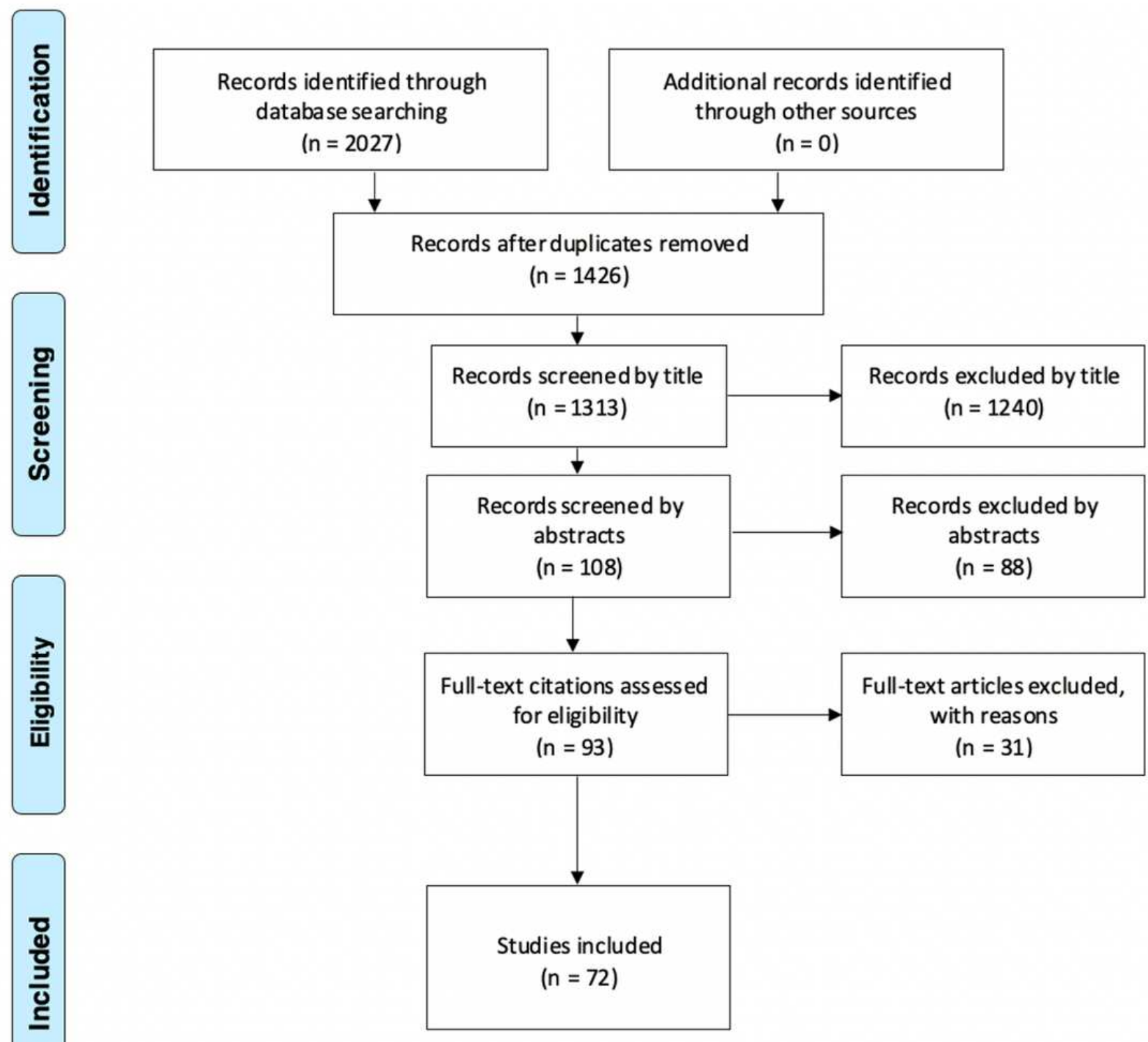

\section{Figure 1}

Systematic Review Profile based on the prisma flow diagram (Moher et al., 2009) 